\title{
Design and Synthesis of Amino Acid Derivatives of Substituted Benzimidazoles and Pyrazoles as Selective Sirt1 Inhibitors
}

Nikil Purushotham, Mrityunjay Singh, Bugga Paramesha, Vasantha Kumar, Sharad Wakode, Sanjay K Banerjee, Boja Poojary, Shailendra Asthana

Submitted date: 25/04/2020 - Posted date: 27/04/2020

Licence: CC BY-NC-ND 4.0

Citation information: Purushotham, Nikil; Singh, Mrityunjay; Paramesha, Bugga; Kumar, Vasantha; Wakode, Sharad; Banerjee, Sanjay K; et al. (2020): Design and Synthesis of Amino Acid Derivatives of Substituted Benzimidazoles and Pyrazoles as Selective Sirt1 Inhibitors. ChemRxiv. Preprint. https://doi.org/10.26434/chemrxiv.12196200.v1

Owing to its presence in several biological processes Sirt1 served as a potential therapeutic target for many diseases. Here we report the synthesis of two distinct series of novel Sirt1 selective inhibitors, benzimidazole monopeptides and 5-pyrazolyl methylidene rhodanine carboxylic acid derived amino acids, constructed using structure-guided computational approaches. Furthermore, compounds were evaluated, against human Sirt1-3 for in-vitro inhibitory activity compared to Ex527 (reported Sirt1-selective inhibitor), in liver and breast cancer cell lines for cytotoxicity. The tryptophan conjugates $13 \mathrm{~h}\left(\mathrm{IC}_{50}=0.66 \mu \mathrm{M}\right)$ and $7 \mathrm{~d}\left(\mathrm{IC}_{50}=0.77 \mu \mathrm{M}\right)$ demonstrated maximum efficacy to inhibit Sirt1. Molecular dynamics simulations unveil the interaction map and electrostatic complementarity at substrate binding site, could be a cause of selective Sirt1 inhibition. Furthermore, the Sirt1 inhibition was monitored via increased p53 acetylation status checked in HepG2 cells. These findings will pave the pathway for developing novel selective Sirt1-inhibitors in cancer therapeutics.

File list (1) 


\section{Design and synthesis of amino acid derivatives of substituted benzimidazoles and pyrazoles}

as selective Sirt1 inhibitors

${ }^{a}$ Department of Studies in Chemistry, Mangalore University, Mangalagangotri, Karnataka-574 199, India.

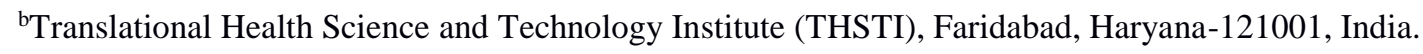

'Delhi Institute of Pharmaceutical Sciences and Research, DPSR University, M.B Road, Pushp Vihar, Sector 3, New

$8 \quad$ Delhi -110017.

9 \# Present address: Department of Biotechnology, National Institute of Pharmaceutical Education and Research

10 (NIPER), Guwahati-781101, India

11

12 \$ These authors contributed equally.

13 *To whom the correspondence should be addressed:

14

\section{3}

\section{Dr. Sanjay K Banerjee}

Translational Health Science and Technology Institute (THSTI),

NCR Biotech Science Cluster, 3rd Milestone

Faridabad - Gurgaon Expressway, Haryana-121001, India

E-Mail: skbanerjee@ thsti.res.in

\section{Dr. Boja Poojary}

Department of Chemistry

Mangalore University

Mangalagangotri-574 199.

Karnataka, India

E-Mail: bojapoojary@gmail.com

\section{Dr. Shailendra Asthana}

Translational Health Science and Technology Institute (THSTI), NCR Biotech Science Cluster, 3rd Milestone

Faridabad - Gurgaon Expressway, Haryana-121001, India

E-Mail: $\underline{\text { sasthana@thsti.res.in }}$ 


\section{ABSTRACT}

2 Owing to its presence in several biological processes Sirt1 served as a potential therapeutic target 3 for many diseases. Here we report the synthesis of two distinct series of novel Sirt1 selective

4 inhibitors, benzimidazole monopeptides and 5-pyrazolyl methylidene rhodanine carboxylic acid 5 derived amino acids, constructed using structure-guided computational approaches. Furthermore, 6 compounds were evaluated, against human Sirt1-3 for in-vitro inhibitory activity compared to 7 Ex527 (reported Sirt1-selective inhibitor), in liver and breast cancer cell lines for cytotoxicity. The 8 tryptophan conjugates $13 \mathrm{~h}\left(\mathrm{IC}_{50}=0.66 \mu \mathrm{M}\right)$ and $7 \mathrm{~d}\left(\mathrm{IC}_{50}=0.77 \mu \mathrm{M}\right)$ demonstrated maximum 9 efficacy to inhibit Sirt1. Molecular dynamics simulations unveil the interaction map and 10 electrostatic complementarity at substrate binding site, could be a cause of selective Sirt1 11 inhibition. Furthermore, the Sirt1 inhibition was monitored via increased p53 acetylation status 12 checked in HepG2 cells. These findings will pave the pathway for developing novel selective Sirt113 inhibitors in cancer therapeutics.

Key words: Selective inhibitor, Sirtuins, Structure activity relationship, Molecular dynamics 17 simulations, Electrostatic surface potential, hot-spot, drug discovery. 
2 Epigenetic regulation is a dynamic and reversible process which can contribute to a broad range 3 of human diseases that includes metabolic, neurological diseases, inflammation and cancer. ${ }^{1}$ In the recent past decade, human homologues of yeast Silent information regulators 2 (Sir2), a class-III lysine deacetylases, also called sirtuins that use $\mathrm{NAD}^{+}$as the co-factor to catalyse the deacetylation of several key cellular histone and non-histone proteins ${ }^{2}$, have emerged as targets for several diseases along with cancer chemotherapy ${ }^{3,4}$. Among a total of seven Sir2 homologs (Sirt1-7) found in mammals, Sirt1, Sirt6 and Sirt7 are predominantly found in the nucleus, Sirt2 in the cytoplasm and Sirt3, Sirt4 and Sirt5 in mitochondria. ${ }^{5}$ All sirtuins have highly conserved NAD-binding, and catalytic core domain with distinct $\mathrm{N}$ - and C-terminal extensions ${ }^{6-8}$. The length of dissimilar Nand C-terminal vary according to the type of binding partners, and its subcellular localization. ${ }^{\mathbf{6 - 8}}$ Among all sirtuins, Sirtl's inhibition gain more attention in the recent years for its role in cancer ${ }^{3}$, rheumatoid arthritis ${ }^{\mathbf{9}, 10}$, HIV $^{\mathbf{1 0}, 11}$ and autophagy ${ }^{12}$.

Sirt1 is the most extensively studied, longest isoform of sirtuins family. It has the NAD ${ }^{+}$ binding catalytic core, which can be further divided into two sub-domains, the Rossmann fold (large) and Zn-binding (smaller) domains. The well-characterized catalytic grove is located at the interface of both sub-domains, where deacetylation of the substrates occurs and most of the reported inhibitors are bound ${ }^{13}$. It deacetylates several non-histone proteins and transcription factors viz. $\mathrm{p} 53^{14}$, forkhead box class $\mathrm{O}(\mathrm{FoxO})^{15}$, nuclear factor $\kappa \mathrm{B}(\mathrm{NF} \kappa \mathrm{B})^{16}$, peroxisome proliferator-activated receptor- $\gamma(\operatorname{PPAR} \gamma)^{17}$, transcriptional co-activator PPAR $\gamma$ coactivator-1 $\alpha$ $(\mathrm{PGC}-1 \alpha)^{18}, \mathrm{Ku} 70 / \mathrm{XRCC}^{19}{ }^{\text {and }}$ histones $^{7}$ such as $\mathrm{H} 1, \mathrm{H} 3$ and $\mathrm{H} 4$, and regulate their function or energy homeostasis. ${ }^{20}$ Therefore, Sirt1 activation, as well as inhibition, appears as attractive and potential mechanisms to combat various diseases associated with aging, metabolic disorder, HIV, neurological disorder and cancer. ${ }^{11,20,21}$

The role of Sirt1 in cancer begins from the finding that, it deacetylates p53 and E2F1, and finally inhibit the apoptosis via modulation of transcriptional activity. Indeed, the role of Sirt1 in cancer is debatable as in some type of cancers it promotes tumorigenesis ${ }^{22}$, while in others like colon cancer, it acts as a tumor suppressor. ${ }^{22}$ Though, the mechanism is not yet known, more exploration is under way to find the role of Sirt1 inhibitors in cancer progression. ${ }^{23,24}$ Recently, some Sirt1 inhibitors are reported in an adjuvant therapy for the treatment of paclitaxel-resistant 
human cervical cancer ${ }^{25}$ and cisplatin-resistant endometrial carcinoma ${ }^{26}$ and other cancers ${ }^{27}$, thus opened up a new avenue to explore the role of Sirt1 inhibitors in resistant cancer cells.

Even though sirtuin's biochemistry has been extensively studied, and many co-crystal structures of several human sirtuin isotypes with inhibitors have been reported till date, due to high amino acid conservity and structural similarity of the catalytic core among sirtuin family members, most of the inhibitors are non-specific and of low micromolar potency viz. Sirtinol, Salermide, Suramin and Cambinol. ${ }^{\mathbf{2 8 - 3 0}}$ In recent years, some isotype-selective sirtuin inhibitors are reported (see Figure 1 for representative structure) but, most of them are Sirt 2 selective. ${ }^{29}$ The pyridine containing inhibitor $\mathbf{1}^{\mathbf{3 1}}$, tryptophan-containing Javamide-II (2) $\mathbf{3}^{\mathbf{3 2}}, 2$,3-disubstituted benzimidazole-

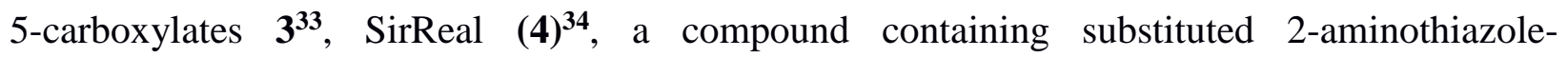

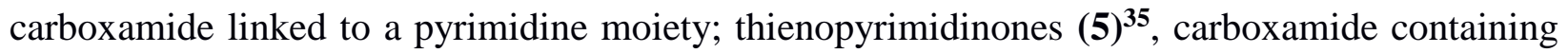
AEM2 (6) ${ }^{\mathbf{3 6}}$ and AGK2 (7) ${ }^{\mathbf{3 7}}$ are reported as highly Sirt2 selective inhibitor. While in case of Sirt1, only two reported inhibitors, carboxamide containing indole $(\mathbf{8})^{\mathbf{3 8}}$ and pyrazole $(\mathbf{9})^{\mathbf{3 9}}$ are known to show moderate Sirt1 selectivity. Similarly, ELT-11c $(\mathbf{1 0})^{\mathbf{4 0}}$, a thienoprimidine analog with coreboxide functionality, is one of the most potent Sirt3 inhibitors reported to date, but is nonselective. Therefore, there is a need to develop more selective Sirt1 inhibitors. Though some recent reports highlighted the link between Sirt1 inhibitor and cancer regulation, there is no information regarding the requirement of selectivity of Sirt1 inhibition for anticancer activity $\mathbf{4 1}$, 42. So far, validation of Sirt1 inhibition for anticancer activity has been hindered by the lack of potent and isotype-specific inhibitor.

In the recent developments in drug design, strategically conjugating amino acid fragments to bioactive heterocycles have proved enhancement of desirable pharmacological features such as low toxicity, high bioavailability, stability and cell permeability with modest potency due to its biocompatibility. ${ }^{43}$ Fascinated by the above-mentioned findings of the inhibitory potential of some 1,2-disubstituted benzimidazole-5-carboxylates and pyrazoles, respectively, along with the significance of incorporating amino acid fragments in bioactive heterocyclic motifs, we explored the potential of some benzimidazole monopeptides and amino acid derived rhodanine carboxylic acid conjugates with pyrazoles as Sirt1 inhibitors. Here, we are reporting the design and synthesis of 1,2-disubstituted benzimidazole monopeptides via one-pot reductive cyclization method and rhodanine acid conjugated pyrazoles via Knoevenagel condensation reactions, and investigation of their Sirt1 inhibitory potential in cell-free and cell-based assays and the plausible mechanism of 
1 inhibition through molecular dynamics simulations. The selective Sirt1 inhibition was also

2 correlated with anticancer activity in two different cell lines.

3

4 RESULTS AND DISCUSSION

5 Chemistry:

6 The synthetic strategy of novel benzimidazole monopeptides is depicted in Scheme 1. Initially,

7 ethyl 4-chloro-3-nitrobenzoate (2) was prepared by esterification of 4-chloro-3-nitrobenzoic acid

8 (1) in refluxing ethanol with a catalytic amount of sulphuric acid. The resulting ester was subjected

9 to nucleophilic aromatic substitution with cyclohexylamine in THF using triethylamine as the base

10 at room temperature to obtain ethyl 4-cyclohexylamino-3-nitrobenzoate (3). Successively, the

11 benzimidazole core was accomplished by sodium dithionite assisted reductive cyclization of ethyl

12 4-cyclohexylamino-3-nitrobenzoate (3) with substituted benzaldehydes in DMSO at $90{ }^{\circ} \mathrm{C}$. The

13 benzimidazole esters (4a-c) were then hydrolyzed to the corresponding carboxylic acids (5a-c) in

14 refluxing aqueous sodium hydroxide solution. These benzimidazole carboxylic acids, when

15 coupled with various amino acid methyl ester hydrochlorides, in presence of $N$-methyl morpholine

16 using TBTU as the coupling agent in DMF media, furnished ester protected benzimidazole

17 monopeptides (6a-l). These monopeptide esters were hydrolyzed to obtain the target

18 benzimidazole monopeptides (7a-l) using lithium hydroxide monohydrate in THF-water mixture

19 at $0{ }^{\circ} \mathrm{C}$.

The synthetic strategy for the rhodanine carboxylic acid conjugated pyrazoles is depicted in

21 Scheme 2. In order to synthesize the final compounds, the two key scaffolds (i) pyrazole aldehyde

22 and (ii) rhodanine acids were initially prepared separately. For the preparation of 3-substituted-

23 1H-pyrazole-4-carboxaldehydes, appropriately substituted acetophenones (8a-c) were heated with

24 semicarbazide hydrochloride in the presence of sodium acetate in acetic acid to obtain the

25 corresponding semicarbazones (9a-c). These on cyclization with phosphorous oxychloride via

26 Vilsmeier Haack reaction furnished 3-substituted-1H-pyrazole-4-carboxaldehydes (10a-c). For the

27 preparation of rhodanine acetic acids (12a-d), suitable amino acids (11a-d) were initially dissolved 
in an aqueous solution of potassium hydroxide and treated with carbon disulfide to obtain the corresponding potassium salt of dithiocarbamates. These on treatment with potassium chloroacetate, followed by heating with $2 \mathrm{~N} \mathrm{HCl}$ solution yielded the 2-(4-oxo-2-thioxothiazolidin3-yl)-amino acids (12a-d). Finally, the two key scaffolds were clubbed together by means of Knoevenagel condensation using beta-alanine as the catalyst to accomplish the target compounds (13a-l) in good yield.

\section{Binding evaluation of all the compounds through Docking and MM-GBSA calculations:} Accurate prediction of binding-site and binding-mode in protein is challenging, however, identification of accurate binding mode inside the binding site is the prerequisite for designing more selective molecules. In order to investigate the structural requirements involved in the amino acid derivatives of benzimidazole and pyrazole class of compounds, we synthesized a total 24 compounds derivatives, 12 from each group, via structure-guided substitution of diverse functionalities to rationalize the Sirt1-inhibitory activity of these compounds in terms of structural modifications. The compounds were first evaluated by molecular docking, followed by thermodynamic calculations through MM-GBSA. The molecules that appeared promising in their docking and MM-GBSA scores were selected for further biological evaluation. Thereafter, molecular dynamics simulations (MD) was performed to prepare the SAR based on stable architecture of binding site and orientations of binding residues to understand the molecular mechanism for selectivity and biological outcomes.

The Ex527 and its analog (Ex527*) belong to the same chemical class and have nearly same binding affinity and $\mathrm{IC}_{50}$ values $\left(\mathrm{IC}_{50} \mathrm{EXX527}_{52}=92 \mu \mathrm{M}, \mathrm{IC}_{50 \_415}=124 \mu \mathrm{M}\right)$, therefore the PDB "4I5I" was selected as a reference for model building, docking and simulation studies. Initially, focused docking and MM-GBSA calculations were performed for Ex527 and Ex527*, by using the centre of mass of Ex527* as a grid centre to check the system reproducibility and benchmark studies (Table S1). It was reported that, inhibitor binding site in sirtuins was flexible and dynamic in nature ${ }^{34}$; therefore, we considered the flexibility of the sirtuin's catalytic and inhibitor binding site and performed MD simulations of Sirt1-Ex527* complex and the best docked pose of Sirt1Ex527 complex, to get the exact binding modes of Ex527 and Ex527*. The overlaid structures (the average structure extracted from last $80 \mathrm{~ns}$ of total $200 \mathrm{~ns}$ MD simulation of each) had shown that both Ex527 and Ex527* were bound at the same place (complex RMSD $0.98 \AA$ ), nested deep 
within the active site, and primarily interacted through pi-pi, hydrophobic and hydrogen bond interactions (Figure 2A and S1). The MM-GBSA ( $\left.-\Delta \mathrm{G}_{\text {bind }}\right)$ and docking scores of Ex527 and Ex527* were $-60.00 \mathrm{kcal} / \mathrm{mol}$ and -6.0 respectively (Table1). Therefore, we took the docking score $(-6.0)$ and $-\Delta \mathrm{G}_{\text {bind }}(-60.0 \mathrm{kcal} / \mathrm{mol})$ as cut-off values for the selection of compounds for further analysis (Figure 2B). Furthermore, after setting the benchmark and cut-off values, the focused docking and MM-GBSA calculations at the above-mentioned grid centre were performed to rescore our library of synthesized molecules. A total of twenty-four amino acid-heterocycle conjugates were designed and synthesized using a combination of various amino acids and two Alanine, Valine, Leucine and Tryptophan (Scheme1, Table 1), whereas, Series2 consisted of twelve substituted pyrazolyl methylidenes of rhodanine carboxylic acids derived from four amino acids viz. Glycine, Alanine, Phenylalanine and Tryptophan (Scheme2, Table 2). A ligand library of total 540 lowest energy conformations was generated from these 24 designed compounds and

\section{Evaluation of Inhibitory Activity:} used for focused docking. Furthermore, MM-GBSA calculations and rescoring were done by Induced Fit docking module, with consideration of protein flexibility up to $5.0 \AA$ to get the most likely orientation of each compound (Table 1 and 2). The compounds qualified to cross the cutoffs are 7a, 7b, 7c, 7d, 7g and 7h (from Series1) and 13d, 13h and 131 (from Series2) were selected for further cell-based biological evaluation.

Enzyme-based study. All compounds selected from Table 1 and 2, initially screened for their inhibitory activity against Human recombinant Sirt1-3 with an in-vitro enzyme-based assay by using Enzo life sciences (Cat No.BML-AK555 for Sirt1, Cat No. BML-AK556 for Sirt2 and Cat No. BML-AK557 for Sirt3). We followed manufacturers' protocol to perform the assay at $10 \mu \mathrm{M}$ concentration using Ex527 as a positive control and DMSO as a negative control. The fluorescently labelled p53-K382 was used as a substrate to measure Human recombinant Sirt1 activity and labelled p53-K320 to measure Human recombinant Sirt2 and Sirt3 activity. At $10 \mu \mathrm{M}$ concentration, Ex527 (positive control) showed inhibition of 98\% (Sirt1), 70\% (Sirt2) and 77\% (Sirt3) (Table S1). However, most compounds showed maximum inhibition activity against Sirt1 and very moderate inhibition activity against Sirt2 and Sirt3. Four compounds 7d, 13d, 13h and 
131 had shown almost $90 \%$ inhibition against Sirt1 which was comparatively close to the positive control (Table 1 and 2).

Cell-based study. Further, to validate the results of enzyme-based assay, we performed cell-based Sirt1-3 enzyme inhibition activity. For this, we treated the HepG2 cells with test compounds at a concentration of $10 \mu \mathrm{M}$ for about $12 \mathrm{~h}$ and followed by evaluation of Sirt1-3 enzymatic activity. In cell-based assay, we found that four compounds $7 \mathrm{~d}, 13 \mathrm{~d}, 13 \mathrm{~h}$ and 131 showed Sirt1 inhibition $8(\geq 30 \%)$ effect similar to positive control Ex527 (33\% Sirt1 inhibition), while compounds 7a, 7b,

7c, $7 \mathrm{~g}$ and $7 \mathrm{~h}$ showed moderate or less inhibitory activity against Sirt1-3 (Table 3). Compounds 7d, 13d, 13h, and 131 showed Sirt1 activity inhibition of 38\%, 36\%, 48\%, and 30\%, respectively. Among all the compounds, $13 \mathrm{~h}$ showed exceptionally high activity against Sirt1, and the inhibition activity trend was $13 \mathrm{~h}>7 \mathrm{~d}>13 \mathrm{~d}>131$. In case of inhibition of Sirt2 and Sirt3 activity together (because of same substrate for both sirtuin's), we observed that compounds 13d, 13h, and 131 showed mild inhibition of $6 \%, 10 \%$ and $9 \%$, respectively, which was very less than activity inhibition showed by Ex527 (Sirt2 and Sirt3 inhibition 15\%). Similar to Ex527, compound 7d also exhibited Sirt2 and Sirt3 inhibition of 19\%. Our study showed that compounds 13d, 13h and 131 were more selective towards Sirt1, while $7 d$ is more towards Sirt2 and Sirt3 in comparison to Ex527.

Dose-response study. Based on the cell-based Sirt1 inhibition activity study, active compounds 7d, 13d, 13h and 131 were selected for dose-response study by using human recombinant Sirt1; and their $\mathrm{IC}_{50}$ values were calculated by using different concentrations of test compounds. Ex527 was used as the standard to compare with the test compounds. Ex527 was used as the standard to compare with the test compounds. Ex527 showed $\mathrm{IC}_{50} 0.60+0.02 \mu \mathrm{M}$ while our test compounds $7 \mathrm{~d}, 13 \mathrm{~d}, 13 \mathrm{~h}$ and 131 showed $\mathrm{IC}_{50}$ values $0.77+0.04 \mu \mathrm{M}, 0.71+0.03 \mu \mathrm{M}, 0.66+0.02 \mu \mathrm{M}$ and $0.73+0.06 \mu \mathrm{M}$, respectively (Table 3).

Viability assay on cancer cell lines. Further to check the anticancer property of our test compounds, two human cancer cell lines, HepG2 (Human liver cancer cell line) and MCF7 (Human breast cancer cell line) were used. To find out the cytotoxicity towards cancer cell lines, MTT assay was performed on both cancer cell lines. We treated the cancer cell lines with different concentrations of our test compounds and Ex527 (1 $\mu \mathrm{M}$ to $400 \mu \mathrm{M})$ for about $24 \mathrm{~h}$. Then we 
performed the cell viability assay and \% viability was calculated. In HepG2 cells, Ex527 and compound $7 \mathrm{~d}$ both exhibited a continuous decrease in cell viability with increasing inhibitor concentration while, compound $7 \mathrm{~d}$ showed moderate decrease in cell viability at higher concentration and, compounds $13 \mathrm{~h}$ and 131 showed comparably very less decrease in cell viability among all compound tested (Figure 3A). In MCF7 cells, 7d similar to the HepG2 cell line showed continuous/comparatively higher decrease in cell viability with increasing inhibitor concentration. However, Ex527 and other test compounds 13d, 13h, and 13l, showed no significant changes in cell viability (Figure 3B).

It was reported earlier that inhibition of Sirt1 and Sirt2 together is necessary for cell death or apoptosis, while selective inhibition of Sirt1 only induced cell cycle arrest at G1-phase but not cell death ${ }^{44,45}$. This means Sirt1 selective inhibition along with Sirt2 inhibition is essential for cytotoxic activity $^{46}$, our data confirmed the same findings. Our cell-based assay showed that both Ex527 and 7d having Sirt 2 and Sirt3 inhibition $15 \%$ and $18 \%$, respectively at $10 \mu \mathrm{M}$ concentration. As the compound 7d has higher Sirt2 and Sirt3 inhibition than control Ex527, it showed higher cell death in both types of cancer cell lines, HepG2, and MCF7. Since, compounds 13d, 13h and 131 were comparatively more selective towards Sirt 1 inhibition, showed very less cell death in cell viability (MTT) assays.

Acetylation status of p53. p53 plays an important role in cancer cell's survival and death. The acetylated form of p53 binds with the DNA and induces the expression of several apoptotic genes and thus acts as a tumor suppressant. ${ }^{47}$ It was reported that Sirt1 primarily deacetylate C-terminal lysine residue (K382) of p53 and enables p53 to bind with DNA, thereby increasing p53 transcriptional activity ${ }^{48}$. So here we wanted to check the acetyl-p53 levels in HepG2 cells in presence of Sirt1 inhibitors that we have designed and positive positive control. We treated the HepG2 cells with $25 \mu \mathrm{M}$ of test compounds for about $48 \mathrm{~h}$. Cell lysates were used for immunoblotting. We found that 7d increased the Ac-p53 levels in HepG2 cells comparable to the positive control, Ex527 (Figure 3C).

These assays outcomes helps to decipher us that $13 \mathrm{~h}$ standout as a Sirt1 selective molecule in comparison with Ex527, and compound $7 \mathrm{~d}$ can be explore futher as anticancer molecule as it is significantly inhibiting the Sirt1 and moderatly inhibiting Sirt2 as well, which is a prerequsite property of a anticancer molecule. (Figure 3). 
Dynamics of protein-ligand systems:

RMSD pattern reflects the dynamics stability of the systems. To rule out the limitations of molecular docking and to understand the molecular recognition process, the role of solvation, the $200 \mathrm{~ns}$ long MD simulations were carried out for each system. Another fact to carry out the MD simulation, as the binding site of Sirt1 is highly flexible in nature and it is solvent exposed, therefore, static docking has limitation to interpret binding affinity and stability. The energy minimized apo and complexes of selected compounds (7d, 13d, 13h and 13l) and the control (Ex527) with Sirt1 were used for subsequent MD simulations. The RMSD of each complex was compared with that of the apo protein. All the complexes showed stable $\mathrm{RMSD}_{\mathrm{avg}} \sim 2.5 \AA$, which was considerably lower than the apo system RMSD avg $3.5 \AA$, and control system, Sirt1-Ex527 $\mathrm{RMSD}_{\text {avg }}$ is $3.0 \AA$, indicating that binding of selected compounds has shown a promising effect in the stability of systems. (Figure 4A). The average RMSD of complex systems Sirt1-7d, Sirt1-13d,

Sirt1-13h and Sirt1-131 were $2.5 \AA, 2.8 \AA, 2.1 \AA$ and $2.8 \AA$, respectively. Since complex Sirt1-13h is the most stable complex among all, it has shown the lowest, smooth and unimodal RMSD distribution. Although, complex Sirt1-13d and Sirt1-131 both had nearly same average RMSD, which was highest among complex systems (Sirt1-7d, Sirt1-13d, Sirt1-13h, Sirt1-131); But Ligand RMSD distribution plot for Sirt1-131 was bimodal while for Sirt1-13d it was unimodal. The bimodal RMSD distribution has shown fluctuation in RMSD and since complex Sirt1-131 unstability increased after $100 \mathrm{~ns}$ from $2.5 \AA$ to $3.0 \AA$, it was noticed that Sirt1-13d is more stable. In cell-based assay the biological inhibitory activity pattern $13 \mathrm{~h}>7 \mathrm{~d}>13 \mathrm{~d}>131$, corroborates well with computational outcomes (Figure 4A, MD stability, 13h>Ex527 7d>13d>131).

Binding of compounds perturbed the dynamic fluctuations. To identify the regions in protein Sirt1 which had gained stability in the complexes, we have performed root mean square fluctuation (RMSF) analysis. The average backbone RMSF value and differences in RMSF ( $\triangle \mathrm{RMSF}$ ) for system Sirt1-Ex527 and Sirt1-7d relative to the apo-system are quantified (Figure 4B). The regions 270-310 that belonged to pocket-C, indicated a significant decrease in RMSF in both the complex systems, Sirt1-Ex527 and Sirt1-7d, compared to the apo-system. Similarly, another region 410 to 460 which belongs to the substrate binding site also reflected substantially decrease in RMSF, in both the complexes. Moreover, Sirt1-7d has shown significant drop in the regions 
260-310 and 410 to 460 than Sirt1-Ex527* (Control); henceforth these regions were considered for further analysis. Interestingly these regions were also used earlier for the designing of inhibitors $^{40,49}$; So, pocket-C and substrate binding sites were selected as two hot-spots for structure-based ligand optimization and protein-ligand interaction studies. The region belonging to pocket-C was called hot-spotl while the region belonging to the substrate binding region was denoted as hot-spot2 in this study (Figure 4B).

Per-residue energy decomposition revealed key residues of the binding sites. The per-residue energy decomposition claimed that in Ex527* (control), a total 9 residues (S265, I270, F273, I279, F297, I316, N346, I347 and I411) reflected major contribution in binding free energies $\left(\Delta \mathrm{G}_{\mathrm{pbsa}} \leq\right.$ $0.5 \mathrm{kcal} / \mathrm{mol}$ ), and among them I347 and N346 contributed highest (Figure 4C). However, in the case of compounds $7 \mathrm{~d}$ and $13 \mathrm{~h}$, around 12 residues showed major contribution to binding free energy $\left(\Delta \mathrm{G}_{\mathrm{pbsa}} \leq-0.5 \mathrm{kcal} / \mathrm{mol}\right)$ (Figure 4C). In 7d, residues, A262, F273, D292, F297, I347, E351, H363, V412, F414, L418, V445 and R446 reflected major contribution in binding free energy and among them F273, H363 from pocket -B \& -C, and L418 and R446 from hot-spot2 contributed highest (Figure 4C and 4D). Similarly, in case of 13h, residues D272, F297, Q345, I347, H363, I411, V412, F413, F414, L418, V445 and R446 showed major contribution and among them, F297, I347, H363 form pocket-B and pocket-C and V412, F413 and F414 from substrate binding site, contributed highest (Figure 4C and 4D). We observed that in Ex527* all 9 residues that played a key role in interaction belong to pocket -B \& -C only and no interaction was observed with residues at substrate binding site. While in case of $7 \mathrm{~d}$ and $13 \mathrm{~h}$ both, residues from all three sites, pocket B \& -C and substrate binding site played major role in interaction (Figure 4C). The residue wise interaction analysis also claims that $7 \mathrm{~d}$ has shown the maximum interaction at $\mathrm{NAD}^{+}$site and pocket-C, while in the case of $13 \mathrm{~h}$, it was gained at the substrate site.

\section{Establishment of Structure-Activity Relationship (SAR):}

Structural study of complex Sirt1-Ex527. As reported by Mellini $\mathrm{P}$ et al. ${ }^{49}$ and others, the catalytic groove was well differentiated into three sub-pockets, pocket A (substrate-binding site), B (NAD + -binding site/I-shaped) and C (NAM binding-pocket). ${ }^{40,}{ }^{49}$ (Figure 2A). In terms of key residues, we identified the area around the residue F414 is denoted as pocket A and interacts with the acetylated lysine of the substrate; region below the residue R274 is denoted as pocket B and 
co-factor NAD/ADPR bind in this pocket; region beneath the residue F273 is denoted as pocket C, also called NAM-binding pocket, and is very critical for deacetylase activity ${ }^{13,} 34$ (Figure S1A). Inhibitors Ex527 and Ex527* (Ex527-analogue) both bind into the pocket-C and hinder the transformation of NAD to L-shape which is required to perform deacetylase function ${ }^{13}$. The pocket-C is made up of two types of residues hydrophobic and polar. Residues F273, Y280, and I347 that covers it from the front- and side- face are forms pi-pi and hydrophobic interactions. Residues, Q345, N346, and D348 form the base of pocket-C and established polar electrostatic interactions (Figure S1B). Both types of interactions appeared necessary for the inhibitory activity of Ex527 and Ex527*.

Structure-activity relationship of both series of compounds. We found that among all synthesized compounds only $7 \mathrm{~d}, 13 \mathrm{~d}, 13 \mathrm{~h}$ and 131 , which had $1 H$-indole substitution at $-\mathrm{R}_{2}$ position, showed good results in cell-based assay in HepG2 cells (Table 3). As shown in 3D interaction map in Figure 4D, the indole moiety of compound 7d, 13d, 13h and 131, localized in C-site and established pi-pi interaction with residue F273, hydrophobic contacts with residues I270, P271 and I347 and polar interactions with residues S265, Y280, Q345, and N346. From the comparison of 2D interaction plot, we found that these compounds have shown interaction maps similar to control Ex527* and Ex527 at pocket -C (Figure S1B and S2). From the interaction map, it was found that the binding of polar and aromatic groups like indole moiety at pocket-C seems to be necessary for the inhibitory activity of the compounds. The MD simulations revealed that some residues at substrate binding site/hot-spot 2 also crucial as they contribute significantly in the stability of compounds and lower down RMSF fluctuation in complex Sirt1-7d compared to control Sirt1-Ex527* and Sirt1-apo. (Figure 4B). Further, we also measured the interaction fraction analysis for all complexes and control (Figure S3). The results of interaction fraction analysis validate the outcome of RMSF, and clearly reflected that $7 \mathrm{~d}, 13 \mathrm{~d}, 13 \mathrm{~h}$ and 131 have additional interaction zone, the substrate site (pocket-A, hot-spot2) compared to Ex527. We observed that at substrate site most of the interactions are electrostatic ( $\mathrm{HBs}$, water bridges and ionics) and dominate the overall interaction contribution in 13d and 131 (Figure S3). As shown in Figure 4D residues, the aromatic residue H363 and substrate binding residues (412-419 and 442449) jointly formed hot-spot2. At hot-spot2, aromatic residues H363 and F414 formed pi-pi or pication interaction with benzimidazole moiety of $7 \mathrm{~d}$ and, pyrazole and rhodanine moiety of $13 \mathrm{~d}$, 
13h and 131; residues L418, V445 formed hydrophobic contact with $\mathrm{R}_{1}$ substituted phenyl moiety, and, the small substitution of 4-OMe/4-NO2/2-Cl-6-F at $\mathrm{R}_{1}$-position, was found to be good for the stability of compounds formed polar, water bridge or direct h-bond contact with basic residue K444 and R446. (Figure 4D and S3). Further analysis of the $2 \mathrm{~d}$ interaction plot (Figure S2) also revealed that compounds $13 \mathrm{~d}, 13 \mathrm{~h}$ and 131 exceptionally form pi-cation interaction with residue F413, which was absent in case of compound $7 \mathrm{~d}$, that could be a reason for more sirt1 selectivity of compound 13d, 13h and 13l. Moreover, Figure 4D reflected that in all three 13d, 13h and 13l, residue R274 and Y280 formed either direct h-bond or water bridge contact with carboxylic acid moiety at pocket-B, which was missing in case of $7 \mathrm{~d}$ due to structural orientation, could be a reason for higher affinity and Sirt1 selectivity of 13d, 13h and 131. These observations are consistent with the Sirt1 selectivity pattern of compounds of pyrazole group viz. 13h and benzimidazole group $7 \mathrm{~d}$ in biological assay.

The structural analysis of docked Sirt1 complexes of 7d, 13d, 13h and 131 reflected that in both benzimidazole and pyrazole class of compounds, the $-\mathrm{R}_{1}$ substitution localized toward the solvent face of substrate pocket and the substitution $-\mathrm{R}_{2}$ is protruded towards the pocket-C (Figure 4D). Similarly, when we superimposed the best docked poses of all the compounds of benzimidazole monopeptide class (Table 1), which had 4-OMe at - $\mathrm{R}_{1}$ substitution, with complex $7 \mathrm{~d}$, we found that the polar aromatic indole moiety which appeared to be crucial for the interaction, was missing in other compounds (Figure 5A), could be a possible reason for the loss of their inhibitory activity. Similarly, as shown in Table 1 three compounds $7 \mathrm{~d}, 7 \mathrm{~h}$ and 71 from benzimidazole class had indole group at $-\mathrm{R}_{2}$ position that was required for the inhibition of Sirt1 biological activity as predicted above, but among them, only $7 \mathrm{~d}$ was found to be active in cellbased assay system (Table 3). We observed that compounds $7 \mathrm{~d}$, 7h and 71 only differ in substitution at $\mathrm{R}_{1}$ position (Figure $\mathbf{5 B}$, Table $\mathbf{1}$ ), and compound $7 \mathrm{~d}$ which had 4-OMe at $\mathrm{R}_{1}$ position showed good inhibition of Sirt 1 catalytic activity. In case of compound $71, \mathrm{R}_{1}$ substitution was "2-Cl", which was at ortho position, and -Cl substitution at ortho position formed steric clash with residue L418 and decreased the MD stability of compound (Figure 5B and 5C), Similarly, in case of compounds 7 h the $\mathrm{R}_{1}$ substitution was $4-\mathrm{F}$ (Figure 5B). During MD simulation it was found that compound $7 \mathrm{~h}$ was comparatively less stable than 7d, (Figure 5C).

Interestingly, as shown in Figure 4D the upper hydrophobic groove which is flexible and made by residues V412 to P419 makes a flexible groove in which phenyl moiety of 7d was trapped 
completely and providing the gain in binding affinity. This groove is a narrow hydrophobic pocket, which could be an area of future exploitation to find additional classes of selective Sirt1 inhibitors. Apart from 7d series, till now none of the inhibitors are able to utilize this groove as it is mostly unavailable due to its flexibility and its vicinity with the substrate binding site. Also, the compound 13h gain additional interaction in the form of stable HBs/water bridge or polar contact by its difluoro group with basic residue K444 and R446 (Figure S3C) that is not reported earlier for any compounds at substrate site that is the interaction with di-fluoro group of $13 \mathrm{~h}$ with R446. This appears, as unique property in case of selectivity as K444 and R446 are present in Sirt1 only (in place of $\mathrm{K}$ and $\mathrm{R}$ it is $\mathrm{Q} / \mathrm{E}$ in Sirt2/3, respectively). Similar interaction also formed in $7 \mathrm{~d}$ but was comparatively weak and transient (Figure S3C).

Possible mechanism of Inhibition:

To get structural insights into the possible inhibition mechanism of identified compounds, we compared our compound $7 \mathrm{~d}$ and $13 \mathrm{~h}$ with the co-crystal structures of other reported best potent sirtuin inhibitor which either in orientation or in size occupying the binding sites, similar to our compounds viz. Ex527* (control, 8), SirReal2 (4) and ELT-11c (10) of different sirtuin analogs, Sirt1, Sirt2 and Sirt3, respectively (Figure S4). The Ex527* binds only in the pocket-C (PDB id. 4I5I), SirReal2 (PDB id. 4RMG) binds in pocket-C and extended selectivity pocket-C, while ELT11c (PDB id. 4JSR) binds at NAD+ site, pocket-C and substrate-binding site, (Figure S4A and S4B). As shown in Figure S4A and S4B, the chemical moieties of $7 \mathrm{~d}$ and $13 \mathrm{~h}$ such as 4methoxyphenyl/3,5-difluorophenyl, benzimidazole/pyrazol, thiazole and indole interact with different key zones of Sirt1 starting from substrate site, $\mathrm{NAD}^{+}$site, and pocket-C, similar to best reported potent Sirt3 inhibitor ELT-11c, but did not interact with extended pocket-C, unlike SirReal2 (potent, selective Sirt2 inhibitor) which is the key known zone for selective Sirt-2 inhibition. Therefore, we compare the reported compounds for the possible mechanism of inhibition of our compounds as they follow the same pose and mode of interactions. Interestingly, the zone pocket-C, the binding site of Ex527 was common in both ELT-11c and SirReal2 and others reported most of the sirtuin inhibitor of different isoform, indicated towards the necessity of pocket-C for potent sirtuin inhibition but less isoform selectivity. The Ex527 binding site thus enables potent sirtuin inhibition, but for further improvement of Ex 527 modifications that possibly 
reach more distant for specificity among isoforms will be required. In this regard, we observed that our compounds 13d, 13h, and 131 have more isoform specificity than Ex527. The overlay of Sirt1 and Sirt3 indicates that the rossmann fold is highly superimposable, and we have observed a fold closure of catalytic binding cavity upon binding to substrates (Figure S4C and S4E) while opposite trend was observed on binding with inhibitor (Figure S4D and S4F). The largest divergence among sirtuins structures occurs at the flexible loop I270 to D292 (Sirt1) or I154 to Y175 (Sirt3), which closes down on the nicotinamide C-pocket. The atomic level observation explored the different interactions and establishment of HBs with different residues of substrate site, NAD+ site and residues of pocket-C. From MD simulations we find that at substrate site apart from direct HBs few water-mediated interactions were also observed. The consistent HBs making residues are R274, Q345, H363, E416 and R446. The recognition motif for the nicotinamide of $\mathrm{NAD}^{+}$is mimicked very well by $7 \mathrm{~d}$ and $13 \mathrm{~h}$ and explains the observed SAR in Table 3. As a result, a substantial reduction of Sirt1 inhibitory activity is observed for compounds protein has a specific electrostatic environment that ligand needs for binding. We compared the $7 \mathrm{~d}$ and $13 \mathrm{~h}$.

Sirt1, Sirt2 and Sirt3 binding sites in terms of electrostatic surface potential (ESP), as the ESP is an important key factor at the region of substrate binding site and played key role in the Sirt1 selectivity and binding of $7 \mathrm{~d}$ (Figure 6). The electrostatic surface potential was calculated via APBS method in scrodinger maestro-2017 for $\mathrm{pH} 7.5$, with a color ramp of \pm 0.5 , from red to blue. As shown in Figure 6C and 6D, the ESP of 7d is in full complementarity to ESP of binding cavity of Sirt1 and it favor the binding of 7d with Sirt1. Furthermore, we observed that in Sirt1 at substrate binding site residues 442-449 have positive ESP while in case of both Sirt2 and Sirt3 the substrate binding site residues, 263-270 (Sirt2) and 321-328 (Sirt3) have negative ESP and appeared red. Since ligand $7 \mathrm{~d}, 13 \mathrm{~d}, 13 \mathrm{~h}$ and 131 all have negative electrostatic potential near substrate binding site, the ESP of protein-ligand complex system in Sirt1 reflected complete ESP complementarity that is favorable for binding in protein Sirt1 (Figure 6E), while in case of Sirt2 (Figure 6F) and Sirt3 (Figure 6G) at substrate binding site, protein and ligand both have negative ESP i.e. Redred combination that is not favorable for binding, and repel to each other and possibly a cause of decrease affinity of 7d and 13h in Sirt2 and Sirt3. In Sirt1 two basic residue, K444 and R446 have positive ESP ie. protein surface in blue color at substrate binding site and act as a selectivity hot- 
spot for interaction, while in case of Sirt2 and Sirt3 the counterpart residues are glutamine (Q265,

2 Q267) and glutamic acid (E321, E325), respectively that make ESP partially negative, and surface of protein appeared red color (Figure 6). This difference in ESP behaviour at substrate binding site in Sirt1, Sirt2 and Sirt3, reflected that the ligand with negative ESP at substrate binding site will be more Sirt1 selective and so, our compounds 7d, 13d, 13h and 131. Many Sirtuin inhibitors previously, targeted the substrate binding site and/or the $\mathrm{NAD}^{+}$pocket for competitive inhibition ${ }^{30}$, 50,51-53, indicated the importance of the substrate binding site for inhibitor designing. From our results, we conclude that substrate binding site ( $\mathrm{N}$ - $\varepsilon$-acetyl lysine binding site) with pocket-C appears to be a prominent site for inhibitor designing, and neighbouring variations with electrostatic complementarity at substrate binding site may enable more isoform-specific inhibition. This data possibly help to understand conformational changes to design for substrate mimics and other acyl-peptide competitive inhibitors.

\section{CONCLUSION}

In summary, two novel series of compounds were designed by conjugating the amino acid moiety to benzimidazole and pyrazole based scaffolds. Both series of compounds were synthesized and evaluated against Sirt1-3 enzymes for their sirtuin inhibitory activity compared to Ex-527. The molecular docking and MM-GBSA calculations of the compounds followed by in vitro enzymatic and cell-based assays revealed that the tryptophan conjugates of both scaffolds were potent and highly selective in inhibiting Sirt1 enzyme over the rest of the homologues with nanomolar potency, comparable to the known inhibitor, Ex-527. The in silico and in vitro based structure activity relationship studies illustrated the need for the compounds to possess a polar aromatic moiety such as indole that can interact with C-pocket and another aromatic ring to interact with Apocket in Sirt1 catalytic domain to exhibit the inhibitory action. Small substitutions such as methoxy, nitro or difluoro on phenyl ring that falls on the solvent exposed sites of the catalytic domain can further improve the stability and selectivity of the enzyme-inhibitor complex. We

27 found that the improved Sirt1 selectivity of our compounds may be due to the presence of strong electrostatic interactions with the two basic residues K444 and R446 at lower cleft of substrate binding site that favors the interactions with electronegative atoms like $\mathrm{O}$ and $\mathrm{F}$ via formation of a multiple hydrogen bonds, water bridge and polar contacts. We observed that, although both ELT11c and our molecules occupied the substrate binding site along with pocket-C, the gain of 
1 selectivity of our compounds may be due to the presence of its interactions and ESP 2 complementarity at substrate binding site. Immuno-blotting of HepG2 cells treated with 3 compounds 7d, 13d, 13h, 131 and Ex527 further confirmed that the decreased Sirt1 enzyme activity 4 is associated with increased acetylated p53 levels. In addition, the cell-viability assay confirmed 5 that on Sirt1 the compounds 13d, 13h and $13 \mathrm{l}$ are less effective to kill cancer cells than the compounds $7 \mathrm{~d}$ and Ex527 which showed a mild inhibition of Sirt2 along with their considerable Sirt 1 inhibition. In a nutshell, 13h standout as a Sirt1 selective molecule in comparison with Ex527, and $7 \mathrm{~d}$ could be explore further as anticancer molecule as it inhibits both Sirt1 and Sirt2. These findings could be helpful for developing a novel selective Sirt1-inhibitors.

\section{EXPERIMENTAL SECTION}

\section{Chemistry:}

All precursor chemicals and solvents were procured from Spectrochem Pvt. Ltd. (India) and Sigma-Aldrich (India) via commercial vendors in suitable grades and used without further purification. The reactions were conducted with a guard tube containing calcium chloride attached to the reaction flask. Open capillary method was used to determine the uncorrected melting points.

Shimadzu FT-IR 157 Spectrometer was used to record the IR spectra. Bruker Avance II - 400 spectrometer was used to record NMR spectra at $400 \mathrm{MHz}$ for ${ }^{1} \mathrm{H}$ and at $100 \mathrm{MHz}$ for ${ }^{13} \mathrm{C}$ nuclei respectively. Tetramethylsilane (TMS) served as an internal standard. The values of coupling constants $(J)$ and the chemical shifts $(\delta)$ are expressed in Hertz and parts per million (ppm) respectively. Agilent Technology LC-Mass spectrometer with ESI ionization was used to record the mass spectra. Elemental analysis was conducted in CHNS Elementar Vario EL III. Thin layer chromatography (TLC) was carried out on a silica coated aluminium sheet (silica gel ${ }^{60} \mathrm{~F}_{254}$ ) to monitor the reaction progress and purity of the compounds using ethyl acetate and hexane solvent systems as mobile phase and visualized under UV light at $254 \mathrm{~nm}$. Column chromatography was performed with 60-120 mesh silica gel. 
2 To a clear solution of ethyl 4-chloro-3-nitrobenzoate (2, $0.01 \mathrm{~mol}, 1.0$ equiv.) in $15 \mathrm{~mL}$ of THF, 3 cyclohexylamine (0.02 mol, 2.0 equiv.) and triethylamine (0.03 mol, 3.0 equiv.) were added and

4 stirred at room temperature for $24 \mathrm{~h}$. Progress of the reaction was monitored by TLC. After 5 completion of the reaction, the reaction mixture was quenched with crushed ice and left

6 undisturbed for two hours. The resulting yellow solid was washed with water, filtered and dried.

7 The crude product was recrystallized from ethyl alcohol to obtain the pure product.

\section{Procedure for the synthesis of benzimidazole esters (4a-c)}

9 Sodium dithionite (0.03 mol, 3.0 equiv.) was added to a clear solution of ethyl 4(cyclohexylamino)-3-nitrobenzoate (3) (0.01 mol; 1.0 equiv.) and substituted benzaldehyde (0.01 mol; 1.0 equiv.) in DMSO (15 mL). The reaction mixture was stirred at $90{ }^{\circ} \mathrm{C}$ for $3 \mathrm{~h}$. After completion of the reaction (monitored by TLC hexane: ethyl acetate $(8: 2, \mathrm{v} / \mathrm{v}))$, the reaction mass was allowed to cool to room temperature and poured onto crushed ice. The solid separated was filtered, washed with water, dried and recrystallized from ethyl alcohol to obtain the pure product.

Ethyl 1-cyclohexyl-2-(4-methoxyphenyl)-1H-benzo[d]imidazole-5-carboxylate (4a): Yield 92\%; Mp 118-120 C; Off white to pale yellow solid; FT IR (ATR, $\left.v_{\max }, \mathrm{cm}^{-1}\right): 3001(\mathrm{Ar}-\mathrm{H}), 2933,2856$ $(\mathrm{C}-\mathrm{H}), 1705(\mathrm{C}=\mathrm{O}), 1610(\mathrm{C}=\mathrm{N}), 1529(\mathrm{C}=\mathrm{C}), 1172(\mathrm{C}-\mathrm{O}) ;{ }^{1} \mathrm{H} \mathrm{NMR}\left(400 \mathrm{MHz}, \mathrm{CDCl}_{3}, \delta \mathrm{ppm}\right)$ : $8.52(\mathrm{~d}, 1 \mathrm{H}, \mathrm{Ar}-\mathrm{H}, J=1.2 \mathrm{~Hz}), 7.97-7.99$ (dd, 1H, Ar-H, $J=1.6$ and $8.8 \mathrm{~Hz}), 7.66$ (d, 1H, Ar-H, $J$ $=8.8 \mathrm{~Hz}), 7.59(\mathrm{~d}, 2 \mathrm{H}, \mathrm{Ar}-\mathrm{H}, J=6.8 \mathrm{~Hz}), 7.07(\mathrm{~d}, 2 \mathrm{H}, \mathrm{Ar}-\mathrm{H}, J=6.8 \mathrm{~Hz}), 4.40-4.45\left(\mathrm{q}, 2 \mathrm{H},-\mathrm{CH}_{2}\right.$ of ethyl, $J=7.2 \mathrm{~Hz}), 4.33-4.39$ (m, 1H, N-CH of cyclohexyl), 3.90 (s, 3H, O-CH 3$), 2.27-2.36$ (m, 2H, cyclohexyl), 1.95-1.99 (m, 4H, cyclohexyl), 1.77-1.79 (m, 1H, cyclohexyl), 1.43 (t, 3H, $-\mathrm{CH}_{3}$ of ethyl, $J=7.2 \mathrm{~Hz}), 1.33-1.38$ (m, 3H, cyclohexyl); $\left.{ }^{13} \mathrm{C} \mathrm{NMR} \mathrm{(100} \mathrm{MHz,} \mathrm{CDCl}_{3}, \delta \mathrm{ppm}\right): 167.2$, 160.9, 155.5, 143.4, 137.3, 130.8, 124.3, 123.4, 122.8, 122.2, 114.2, 112.0, 60.8, 57.1, 55.4, 31.4, 25.9, 25.2, 14.4; ESI-MS (m/z): $379.2[\mathrm{M}+\mathrm{H}]^{+}$; Anal. calcd. for $\mathrm{C}_{23} \mathrm{H}_{26} \mathrm{~N}_{2} \mathrm{O}_{3}: \mathrm{C}, 72.99 ; \mathrm{H}, 6.92 ; \mathrm{N}$, 25 7.40. Found: C, 72.97; H, 6.94; N, 7.37. 
Ethyl 1-cyclohexyl-2-(4-fluorophenyl)-1H-benzo[d]imidazole-5-carboxylate (4b): Yield 87\%;

2 Mp 130-132 ${ }^{\circ}$; Off white to pale brown solid; FT IR (ATR, v $v_{\max }, \mathrm{cm}^{-1}$ ): 3050 (Ar-H), 2927, 2850

(C-H), 1705 (C=O), 1602 (C=N), 1527 (C=C), 1300 (C-O), 1224 (C-F); ${ }^{1} \mathrm{H}$ NMR (400 MHz, $\left.\mathrm{CDCl}_{3}, \delta \mathrm{ppm}\right): 8.52(\mathrm{~d}, 1 \mathrm{H}, \mathrm{Ar}-\mathrm{H}, J=1.2 \mathrm{~Hz}), 7.99-8.02$ (dd, $1 \mathrm{H}, \mathrm{Ar}-\mathrm{H}, J=1.6$ and $\left.8.8 \mathrm{~Hz}\right), 7.67$ (d, 1H, Ar-H, J = 8.8 Hz), 7.62-7.66 (m, 2H, Ar-H), 7.23-7.27 (m, 2H, Ar-H), 4.4-4.45 (q, 2H, $\mathrm{CH}_{2}$ of ethyl group, $\left.J=7.2 \mathrm{~Hz}\right), 4.29-4.35(\mathrm{~m}, 1 \mathrm{H}$, cyclohexyl $\mathrm{N}-\mathrm{CH}), 2.27-2.36(\mathrm{~m}, 2 \mathrm{H}$, cyclohexyl), 1.95-2.03 (m, 4H, cyclohexyl), 1.76-1.8 (m, 1H, cyclohexyl), 1.43 (t, 3H, - $\mathrm{CH}_{3}$ of ethyl group, $J=7.2 \mathrm{~Hz}), 1.35-1.36\left(\mathrm{~m}, 3 \mathrm{H}\right.$, cyclohexyl); ${ }^{13} \mathrm{C} \mathrm{NMR}\left(100 \mathrm{MHz}, \mathrm{CDCl}_{3}, \delta \mathrm{ppm}\right)$ : 167.1, 164.9, 162.5, 154.4, 143.3, 137.1, 131.5, 131.4, 126.8, 124.6, 123.7, 122.46, 116.0, 115.9, 112.1, 60.8, 57.3, 31.5, 25.9, 25.2, 14.4; ESI-MS $(\mathrm{m} / \mathrm{z})$ : $367.3[\mathrm{M}+\mathrm{H}]^{+}$; Anal. calcd. for $\mathrm{C}_{22} \mathrm{H}_{23} \mathrm{~N}_{2} \mathrm{FO}_{2}$ : C, 72.11; H, 6.33; N, 7.64. Found: C, 72.10; H, 6.29; N, 7.62.

Ethyl 2-(2-chloro-6-fluorophenyl)-1-cyclohexyl-1H-benzo[d]imidazole-5-carboxylate (4c): Yield 82\%; Mp 104-106 C; Pale yellow crystalline solid; FT IR (ATR, vmax $\mathrm{cm}^{-1}$ ): 3000 (Ar-H), 2943, $2858(\mathrm{C}-\mathrm{H}), 1710(\mathrm{C}=\mathrm{O}), 1618(\mathrm{C}=\mathrm{N}), 1570$ (C=C), 1298 (C-O), 1249 (C-F), 790 (C-Cl); ${ }^{1} \mathrm{H}$ NMR (400 MHz, $\mathrm{CDCl}_{3}, \delta$ ppm): 8.49 (d, 1H, Ar-H, $\left.J=1.6 \mathrm{~Hz}\right), 7.9-7.97$ (dd, 1H, Ar-H, $J=$ 1.6 and $8.8 \mathrm{~Hz}), 7.61$ (d, 1H, Ar-H, $J=8.4 \mathrm{~Hz}), 7.39-7.45(\mathrm{~m}, 1 \mathrm{H}, \mathrm{Ar}-\mathrm{H}), 7.31(\mathrm{~d}, 1 \mathrm{H}, \mathrm{Ar}-\mathrm{H}, J=$ $8.0 \mathrm{~Hz}), 7.10(\mathrm{t}, 1 \mathrm{H}, \mathrm{Ar}-\mathrm{H}, J=8.4 \mathrm{~Hz}), 4.32-4.37$ (q, 2H, $-\mathrm{CH}_{2}$ of ethyl group, $\left.J=6.8 \mathrm{~Hz}\right), 3.74-$ 3.81 (m, 1H, cyclohexyl N-CH), 2.05-2.14 (m, 2H, cyclohexyl), 1.83-1.99 (m, 4H, cyclohexyl), $1.67\left(\mathrm{~m}, 1 \mathrm{H}\right.$, cyclohexyl), $1.34\left(\mathrm{t}, 3 \mathrm{H},-\mathrm{CH}_{3}\right.$ of ethyl group, $\left.J=6.8 \mathrm{~Hz}\right), 1.20-1.21(\mathrm{~m}, 3 \mathrm{H}$, cyclohexyl); ${ }^{13} \mathrm{C} \mathrm{NMR}\left(100 \mathrm{MHz}, \mathrm{CDCl}_{3}, \delta \mathrm{ppm}\right): 167.0,162.8,160.3,146.7,143.6,136.5,136.1$, 132.4, 132.3, 125.6, 124.6, 124.0, 122.9, 119.5, 119.3, 114.5, 114.3, 111.8, 60.8, 57.9, 31.4, 25.9, 25.2, 14.4; ESI-MS $(\mathrm{m} / z): 401.3[\mathrm{M}+\mathrm{H}]^{+}, 403.3[\mathrm{M}+2+\mathrm{H}]^{+}$; Anal. calcd. for $\mathrm{C}_{22} \mathrm{H}_{22} \mathrm{~N}_{2} \mathrm{ClFO}_{2}$ : C, 65.91; H, 5.53; N, 6.99. Found: C, 65.89; H, 5.51; N, 7.02.

\section{Procedure for the synthesis of benzimidazole carboxylic acids (5a-c)}

To a clear solution of $\mathbf{4}$ a-c $(0.01 \mathrm{~mol})$ in minimum amount of ethanol, catalytic amount of sodium hydroxide in $20 \mathrm{~mL}$ of water was added and the solution was refluxed for $3 \mathrm{~h}$. After the completion of the reaction (monitored by TLC, hexane: ethyl acetate $(8: 2, \mathrm{v} / \mathrm{v})$ ), the cooled reaction mixture 
was poured onto crushed ice and acidified with dilute $\mathrm{HCl}$. The solid obtained was washed with water, filtered, dried and recrystallized from ethyl alcohol to obtain pure product.

1-Cyclohexyl-2-(4-methoxyphenyl)-1H-benzo[d]imidazole-5-carboxylic acid (5a): Yield 92\%; Mp 244-246 ${ }^{\circ} \mathrm{C}$; Off white solid; FT IR (ATR, $\left.v_{\max }, \mathrm{cm}^{-1}\right): 3462$ (O-H), 3001 (Ar-H), 2933, 2856 $(\mathrm{C}-\mathrm{H}), 1702(\mathrm{C}=\mathrm{O}), 1610(\mathrm{C}=\mathrm{N}), 1529(\mathrm{C}=\mathrm{C}), 1172(\mathrm{C}-\mathrm{O}) ;{ }^{1} \mathrm{H}$ NMR (400 MHz, DMSO-d,$\delta$ ppm): 12.81 (bs, $\left.1 \mathrm{H}, \mathrm{CO}_{2} \mathrm{H}\right), 8.53$ (d, 1H, Ar-H, $J=1.2 \mathrm{~Hz}$ ), 7.97-7.99 (dd, 1H, Ar-H, $J=1.6$ and $8.8 \mathrm{~Hz}$ ), 7.66 (d, 1H, Ar-H, J=8.8 Hz), 7.59 (d, 2H, Ar-H, J=6.8 Hz), 7.07 (d, 2H, Ar-H, $J=6.8$ $\mathrm{Hz}$ ), 4.33-4.39 (m, 1H, N-CH of cyclohexyl), 3.90 (s, 3H, O-CH ( $_{3}$, 2.27-2.36 (m, 2H, cyclohexyl), 1.95-1.99 (m, 4H, cyclohexyl), 1.77-1.79 (m, 1H, cyclohexyl), 1.33-1.38 (m, 3H, cyclohexyl); ${ }^{13} \mathrm{C}$ NMR (100 MHz, DMSO- $d_{6}, \delta$ ppm): 167.3, 160.9, 155.5, 143.4, 137.3, 130.8, 124.3, 123.4, 122.8, 122.2, 114.2, 112.0, 57.1, 55.4, 31.4, 25.9, 25.2; ESI-MS $(\mathrm{m} / \mathrm{z}): 351.1[\mathrm{M}+\mathrm{H}]^{+}$; Anal. calcd. for $\mathrm{C}_{21} \mathrm{H}_{22} \mathrm{~N}_{2} \mathrm{O}_{3}$ : C, 71.98; H, 6.33; N, 7.99. Found: C, 71.97; H, 6.30; N, 7.94.

1-Cyclohexyl-2-(4-fluorophenyl)-1H-benzo[d]imidazole-5-carboxylic acid (5b): Yield 94\%; Mp 248-250 ${ }^{\circ} \mathrm{C}$; Off white solid; FT IR (ATR, $v_{\max }, \mathrm{cm}^{-1}$ ): 3450 (O-H), 3050 (Ar-H), 2927, 2850 (C$\mathrm{H}), 1703(\mathrm{C}=\mathrm{O}), 1601(\mathrm{C}=\mathrm{N}), 1527(\mathrm{C}=\mathrm{C}), 1300(\mathrm{C}-\mathrm{O}), 1224$ (C-F); ${ }^{1} \mathrm{H}$ NMR (400 MHz, DMSO$\left.d_{6}, \delta \mathrm{ppm}\right): 12.80\left(\mathrm{bs}, 1 \mathrm{H}, \mathrm{CO}_{2} \mathrm{H}\right), 8.51(\mathrm{~d}, 1 \mathrm{H}, \mathrm{Ar}-\mathrm{H}, J=1.2 \mathrm{~Hz}), 7.99-8.02$ (dd, $1 \mathrm{H}, \mathrm{Ar}-\mathrm{H}, J=$ 1.6 and $8.8 \mathrm{~Hz}), 7.67$ (d, 1H, Ar-H, $J=8.8 \mathrm{~Hz}), 7.62-7.66(\mathrm{~m}, 2 \mathrm{H}, \mathrm{Ar}-\mathrm{H}), 7.23-7.27$ (m, 2H, Ar$\mathrm{H})$, 4.29-4.35 (m, 1H, cyclohexyl N-CH), 2.27-2.36 (m, 2H, cyclohexyl), 1.95-2.03 (m, 4H, cyclohexyl), 1.76-1.8 (m, 1H, cyclohexyl), 1.35-1.36 (m, 3H, cyclohexyl); ${ }^{13} \mathrm{C}$ NMR (100 MHz, DMSO- $d_{6}, \delta$ ppm): 167.1, 164.9, 162.5, 154.4, 143.3, 137.1, 131.5, 131.4, 126.8, 124.6, 123.7, 122.46, 116.0, 115.9, 112.1, 57.3, 31.5, 25.9, 25.2; ESI-MS $(\mathrm{m} / z): 339.3[\mathrm{M}+\mathrm{H}]^{+}$; Anal. calcd. for $\mathrm{C}_{20} \mathrm{H}_{19} \mathrm{~N}_{2} \mathrm{FO}_{2}$ : C, 70.99; H, 5.66; N, 8.28. Found: C, 70.97; H, 5.62; N, 8.24.

2-(2-Chloro-6-fluorophenyl)-1-cyclohexyl-1H-benzo[d]imidazole-5-carboxylic acid (5c): Yield 96\%; Mp 232-234 ${ }^{\circ} \mathrm{C}$; Off white solid; FT IR (ATR, $\left.v_{\max }, \mathrm{cm}^{-1}\right)$ : $3500(\mathrm{O}-\mathrm{H}), 2941,2862(\mathrm{C}-\mathrm{H})$, $1706(\mathrm{C}=\mathrm{O}), 1620(\mathrm{C}=\mathrm{N}), 1572(\mathrm{C}=\mathrm{C}), 1298(\mathrm{C}-\mathrm{O}), 1248(\mathrm{C}-\mathrm{F}), 779(\mathrm{C}-\mathrm{Cl}) ;{ }^{1} \mathrm{H}$ NMR $(400 \mathrm{MHz}$, DMSO- $d_{6}, \delta$ ppm): 12.82 (bs, $\left.1 \mathrm{H}, \mathrm{CO}_{2} \mathrm{H}\right), 8.30$ (s, 1H, Ar-H), 8.01 (d, 1H, Ar-H, J=12.0 Hz), $7.93(\mathrm{~d}, 1 \mathrm{H}, \mathrm{Ar}-\mathrm{H}, J=8.4 \mathrm{~Hz}), 7.73-7.71(\mathrm{~m}, 1 \mathrm{H}, \mathrm{Ar}-\mathrm{H}), 7.63(\mathrm{~d}, 1 \mathrm{H}, \mathrm{Ar}-\mathrm{H}, J=8.0 \mathrm{~Hz}), 7.51$ (t, $1 \mathrm{H}, \mathrm{Ar}-\mathrm{H}, J=8.0 \mathrm{~Hz}), 3.84-3.90$ (m, 1H, cyclohexyl N-CH), 2.14-2.23 (m, 2H, cyclohexyl), 1.781.92 (m, 4H, cyclohexyl), 1.58 (m, 1H, cyclohexyl), 1.23-1.32 (m, 3H, cyclohexyl); ${ }^{13} \mathrm{C}$ NMR (100 
MHz, DMSO- $d_{6}, \delta$ ppm): 167.6, 161.9, 159.5, 146.1, 143.0, 136.5, 136.1, 134.7, 132.3, 125.9, 124.7, 123.8, 121.5, 118.4, 118.2, 115.1, 114.9, 112.7, 57.2, 30.7, 25.2, 24.3; ESI-MS (m/z): 373.3 $[\mathrm{M}+\mathrm{H}]^{+}, 375.3[\mathrm{M}+2+\mathrm{H}]^{+}$; Anal. calcd. for $\mathrm{C}_{20} \mathrm{H}_{18} \mathrm{~N}_{2} \mathrm{ClFO}_{2}: \mathrm{C}, 64.43 ; \mathrm{H}, 4.87 ; \mathrm{N}, 7.51$. Found: $\mathrm{C}$, $64.41 ; \mathrm{H}, 4.83 ; \mathrm{N}, 7.54$.

\section{Procedure for the synthesis of benzimidazole monopeptide esters (6a-l)}

To a clear solution of 5a-c $(0.01 \mathrm{~mol})$ in $15 \mathrm{~mL}$ of DMF, NMM (0.025 mol, 2.5 equiv. $)$ and TBTU (0.0125 mol, 1.25 equiv.) were added and stirred for an hour at room temperature. To the clear resulting solution, amino acid methyl ester hydrochloride ( $0.01 \mathrm{~mol}, 1.0$ equiv.) was added and stirred at room temperature for $4 \mathrm{~h}$. After completion of the reaction (monitored by TLC hexane: ethyl acetate $(7: 3, v / v))$, the reaction mass was poured onto crushed ice. The precipitated solid was washed with water, filtered, dried and column purified to obtain the pure product.

\section{Methyl (S)-(1-cyclohexyl-2-(4-methoxyphenyl)-1H-benzo[d]imidazole-5-carbonyl)alaninate} (6a): Yield 90\%; Mp 134-136 ${ }^{\circ} \mathrm{C}$; Off white solid; FT IR (ATR, v $v_{\max }, \mathrm{cm}^{-1}$ ): 3078 (Ar-H), 2935 and $2854(\mathrm{C}-\mathrm{H}), 1726(\mathrm{C}=\mathrm{O}$ of ester), $1652(\mathrm{C}=\mathrm{O}$ of amide), $1612(\mathrm{C}=\mathrm{N}), 1577(\mathrm{C}=\mathrm{C}), 1029(\mathrm{C}$ O); ${ }^{1} \mathrm{H}$ NMR (400 MHz, $\mathrm{CDCl}_{3}, \delta$ ppm): 8.65 (d, 1H, amide N-H, J=7.2 Hz), 8.27 (d, 1H, Ar-H, $J=1.2 \mathrm{~Hz}), 7.90(\mathrm{~d}, 1 \mathrm{H}, \mathrm{Ar}-\mathrm{H}, J=8.4 \mathrm{~Hz}), 7.79-7.82(\mathrm{dd}, 1 \mathrm{H}, \mathrm{Ar}-\mathrm{H}, J=1.6$ and $7.2 \mathrm{~Hz}), 7.61(\mathrm{~d}$, 1H, Ar-H, $J=8.8 \mathrm{~Hz}$ ), 7.15 (d, 1H, Ar-H, $J=9.2 \mathrm{~Hz}$ ), 4.42-4.49 (m, 1H, chiral CH), 4.26-4.32 (m, 1H, N-CH), $3.86\left(\mathrm{~s}, 3 \mathrm{H}, \mathrm{OCH}_{3}\right), 3.79\left(\mathrm{~s}, 3 \mathrm{H}, \mathrm{OCH}_{3}\right), 2.25-2.33(\mathrm{~m}, 2 \mathrm{H}$, cyclohexyl), 1.84-1.92 (m, 4H, cyclohexyl), 1.63-1.66 (m, 1H, cyclohexyl), 1.42-1.44 (d, 3H, $\left.\mathrm{CH}_{3}, J=7.2 \mathrm{~Hz}\right), 1.23-1.39$ (m, 3H, cyclohexyl); ${ }^{13} \mathrm{C}$ NMR (100 MHz, $\mathrm{CDCl}_{3}, \delta$ ppm): 174.4, 166.4, 160.4, 154.7, 142.8, 135.7, 130.8, 127.5, 122.5, 121.6, 118.7, 114.2, 112.4, 56.7, 55.3, 51.9, 48.2, 30.5, 25.5, 24.4, 16.9; ESI-MS (m/z): $436.2[\mathrm{M}+\mathrm{H}]^{+}$; Anal. calcd. for $\mathrm{C}_{25} \mathrm{H}_{29} \mathrm{~N}_{3} \mathrm{O}_{4}: \mathrm{C}, 68.95 ; \mathrm{H}, 6.71 ; \mathrm{N}, 9.65$. Found: $\mathrm{C}$, 68.96; H, 6.70; N, 9.62.

Methyl (S)-(1-cyclohexyl-2-(4-methoxyphenyl)-1H-benzo[d]imidazole-5-carbonyl)valinate (6b): Yield 62\%; Mp 68-70 ${ }^{\circ} \mathrm{C}$; Off white solid; FT IR (ATR, $v_{\max }, \mathrm{cm}^{-1}$ ): 3409 (NH), 3100 (ArH), 2935 and $2850(\mathrm{C}-\mathrm{H}), 1722(\mathrm{C}=\mathrm{O}$ of ester), $1650(\mathrm{C}=\mathrm{O}$ of amide), $1612(\mathrm{C}=\mathrm{N}), 1581(\mathrm{C}=\mathrm{C})$, 1029 (C-O); ${ }^{1} \mathrm{H}$ NMR (400 MHz, $\mathrm{CDCl}_{3}, \delta$ ppm): 8.33 (d, 1H, amide NH, $J=8.0 \mathrm{~Hz}$ ); 8.27 (d, 
1H, Ar-H, $J=1.2 \mathrm{~Hz}$ ), 7.89 (d, 1H, Ar-H, $J=8.8 \mathrm{~Hz}$ ), 7.78-7.80 (dd, 1H, Ar-H, $J=1.6$ and 8.4 $\mathrm{Hz}), 7.61(\mathrm{~d}, 2 \mathrm{H}, \mathrm{Ar}-\mathrm{H}, J=8.8 \mathrm{~Hz}), 7.15$ (d, 2H, Ar-H, $J=8.8 \mathrm{~Hz}), 4.26-4.32(\mathrm{~m}, 2 \mathrm{H}, \mathrm{N}-\mathrm{CH}$ and chiral $\mathrm{CH}), 3.86\left(\mathrm{~s}, 3 \mathrm{H}, \mathrm{OCH}_{3}\right), 3.79\left(\mathrm{~s}, 3 \mathrm{H}, \mathrm{OCH}_{3}\right), 2.19-2.33(\mathrm{~m}, 3 \mathrm{H}, \mathrm{CH}$ and cyclohexyl), 1.841.90 (m, 4H, cyclohexyl), 1.63-1.66 (m, 1H, cyclohexyl), 1.23-1.41 (m, 3H, cyclohexyl), 0.971.01 (m, 6H, diastereotopic $\left.\mathrm{CH}_{3}\right) ;{ }^{13} \mathrm{C} \mathrm{NMR}\left(100 \mathrm{MHz}, \mathrm{CDCl}_{3}, \delta \mathrm{ppm}\right): 174.3,166.9,160.4,154.6$, $142.7,135.7,130.8,127.8,122.5,121.7,118.8,114.2$, 112.4, 58.6, 56.7, 55.3, 51.8, 30.5, 29.6, 25.5, 24.4, 19.4, 18.8; ESI-MS (m/z): $464.4[\mathrm{M}+\mathrm{H}]^{+}$; Anal. calcd. for $\mathrm{C}_{27} \mathrm{H}_{33} \mathrm{~N}_{3} \mathrm{O}_{4}$ : C, 69.96; $\mathrm{H}$, 7.18; N, 9.06. Found: C, 69.94; H, 7.15; N, 9.03.

Methyl (S)-(1-cyclohexyl-2-(4-methoxyphenyl)-1H-benzo[d]imidazole-5-carbonyl)leucinate (6c): Yield 75\%; Mp: 82-84 ${ }^{\circ}$; Off white solid; FT IR (ATR, $v_{\max }, \mathrm{cm}^{-1}$ ): $3074(\mathrm{Ar}-\mathrm{H}), 2935$ and $2862(\mathrm{C}-\mathrm{H}), 1726(\mathrm{C}=\mathrm{O}$ of ester), $1650(\mathrm{C}=\mathrm{O}$ of amide), $1612(\mathrm{C}=\mathrm{N}), 1577(\mathrm{C}=\mathrm{C}), 1029(\mathrm{C}-\mathrm{O})$; ${ }^{1} \mathrm{H}$ NMR (400 MHz, $\left.\mathrm{CDCl}_{3}, \delta \mathrm{ppm}\right): 8.33(\mathrm{~d}, 1 \mathrm{H}$, amide $\mathrm{NH}, J=6.8 \mathrm{~Hz}), 8.23(\mathrm{~s}, 1 \mathrm{H}, \mathrm{Ar}-\mathrm{H}), 7.88$ $(\mathrm{d}, 1 \mathrm{H}, \mathrm{Ar}-\mathrm{H}, J=8.4 \mathrm{~Hz}), 7.78(\mathrm{~d}, 1 \mathrm{H}, \mathrm{Ar}-\mathrm{H}, J=8.4 \mathrm{~Hz}), 7.60(\mathrm{~d}, 1 \mathrm{H}, \mathrm{Ar}-\mathrm{H}, J=8.4 \mathrm{~Hz}), 7.14$ (d, $1 \mathrm{H}, \mathrm{Ar}-\mathrm{H}, J=8.8 \mathrm{~Hz}), 4.37-4.40(\mathrm{~m}, 1 \mathrm{H}$, chiral CH), 4.25-4.31 (m, 1H, C-NH), 3.86 (s, 3H, $\left.\mathrm{OCH}_{3}\right), 3.79$ (s, 3H, $\left.\mathrm{OCH}_{3}\right), 2.24-2.33$ (m, 2H, cyclohexyl), 1.83-1.90 (m, 4H, cyclohexyl), 1.62$1.76\left(\mathrm{~m}, 4 \mathrm{H}\right.$, isobutyl $\mathrm{CH}, \mathrm{CH}_{2}$ and cyclohexyl), 1.24-1.41 (m, 3H, cyclohexyl), 0.89-0.92 (m, 6H, diastereotopic $\left.\mathrm{CH}_{3}\right) ;{ }^{13} \mathrm{C}$ NMR (100 $\left.\mathrm{MHz} \mathrm{CDCl}_{3}, \delta \mathrm{ppm}\right): 174.4,166.4,160.4,154.6,142.8$, 135.6, 130.8, 128.0, 122.5, 121.5, 118.6, 114.2, 112.4, 56.6, 55.3, 52.2 , 30.5, 29.6, 25.5, 24.6, 23.0, 21.6, 18.9; ESI-MS (m/z): 478.4 [M+H] $]^{+}$; Anal. calcd. for $\mathrm{C}_{28} \mathrm{H}_{35} \mathrm{~N}_{3} \mathrm{O}_{4}$ : C, 70.42; H, 7.39; N, 8.80. Found: C, 70.40; H, 7.35; N, 8.81.

Methyl (S)-(1-cyclohexyl-2-(4-methoxyphenyl)-1H-benzo[d]imidazole-5-carbonyl)tryptophanate (6d): Yield 99\%, Mp: $86-88^{\circ} \mathrm{C}$; Off white to pale brown solid; FT IR (ATR, $v_{\max }, \mathrm{cm}^{-1}$ ): 3055 (Ar-H), 2933 and $2856(\mathrm{C}-\mathrm{H}), 1728$ (C=O of ester), $1643(\mathrm{C}=\mathrm{O}$ of amide), $1612(\mathrm{C}=\mathrm{N}), 1577$ $(\mathrm{C}=\mathrm{C}), 1178(\mathrm{C}-\mathrm{O}) ;{ }^{1} \mathrm{H}$ NMR (400 MHz, $\left.\mathrm{CDCl}_{3}, \delta \mathrm{ppm}\right): 10.81(\mathrm{~s}, 1 \mathrm{H}$, indole $\mathrm{NH}), 8.62(\mathrm{~d}, 1 \mathrm{H}$, amide $\mathrm{NH}, J=7.6 \mathrm{~Hz}), 8.20(\mathrm{~d}, 1 \mathrm{H}, \mathrm{Ar}-\mathrm{H}, J=1.6 \mathrm{~Hz}), 7.88(\mathrm{~d}, 1 \mathrm{H}, \mathrm{Ar}-\mathrm{H}, J=8.4 \mathrm{~Hz}), 7.72-7.75$ (dd, 1H, Ar-H, $J=8.4$ and 1.6 Hz), 7.59-7.63 (m, 3H, Ar-H), 7.32 (d, 1H, Ar-H, $J=8.0 \mathrm{~Hz}), 7.23$ (d, 1H, Ar-H, J = 2.0 Hz), 7.15 (d, 2H, Ar-H, J = 8.8 Hz), 7.04-7.08 (m, 1H, Ar-H), 6.97-7.01 (m, 1H, Ar-H), 4.66-4.72 (m, 1H, chiral CH), 4.25-4.31 (m, 1H, C-NH), 3.86 (s, 3H, OCH $), 3.79$ (s, $\left.3 \mathrm{H}, \mathrm{OCH}_{3}\right), 2.23-2.29$ (m, 2H, cyclohexyl), 1.83-1.89 (m, 4H, cyclohexyl), 1.62-1.65 (m, 1H, cyclohexyl), 1.25-1.41 (m, 3H, cyclohexyl); ${ }^{13} \mathrm{C} \mathrm{NMR} \mathrm{(100} \mathrm{MHz,} \mathrm{CDCl}_{3}, \delta$ ppm): 173.7, 166.6, 
$160.4,154.6,142.6,136.1,135.6,130.9,127.6,127.1,125.76,123.6,121.6,120.9,118.5,118.4$, 118.1, 114.2, 112.5, 111.4, 110.5, 56.7, 55.3, 53.7, 52.4, 30.5, 26.6, 25.5, 24.3; ESI-MS (m/z): $551.3[\mathrm{M}+\mathrm{H}]^{+}$; Anal. calcd. for $\mathrm{C}_{33} \mathrm{H}_{34} \mathrm{~N}_{4} \mathrm{O}_{4}$ : C, 71.98; H, 6.22; N, 10.17. Found: C, 71.95; H, 6.20; $\mathrm{N}, 10.13$

Methyl (S)-(1-cyclohexyl-2-(4-fluorophenyl)-1H-benzo[d]imidazole-5-carbonyl)alaninate (6e): Yield 86\%; Mp 128-130 ${ }^{\circ} \mathrm{C}$; Off white solid; IR (ATR, $v_{\max }, \mathrm{cm}^{-1}$ ): $3071(\mathrm{Ar}-\mathrm{H}), 2932$ and 2861 (C-H), $1730(\mathrm{C}=\mathrm{O}$ of ester), $1653(\mathrm{C}=\mathrm{O}$ of amide), $1614(\mathrm{C}=\mathrm{N}), 1578(\mathrm{C}=\mathrm{C}), 1265(\mathrm{C}-\mathrm{O}), 1230$ (C-F); ${ }^{1} \mathrm{H}$ NMR (400 MHz, $\mathrm{CDCl}_{3}, \delta$ ppm): 8.63 (d, 1H, amide N-H, J=7.2 Hz), 8.29 (s, 1H, ArH), $7.93(\mathrm{~d}, 1 \mathrm{H}, \mathrm{Ar}-\mathrm{H}, J=8.8 \mathrm{~Hz}), 7.83(\mathrm{~d}, 1 \mathrm{H}, \mathrm{Ar}-\mathrm{H}, J=8.8 \mathrm{~Hz}), 7.71-7.75$ (m, 2H, Ar-H), 7.427.46 (m, 2H, Ar-H), 4.41-4.48 (m, 1H, chiral CH), 4.20-4.26 (m, 1H, N-CH), 3.79 (s, 3H, OCH , 2.24-2.32 (m, 2H, cyclohexyl), 1.83-1.93 (m, 4H, cyclohexyl), 1.63-1.66 (m, 1H, cyclohexyl), 1.42-1.44 (d, 3H, $\left.\mathrm{CH}_{3}, J=7.2 \mathrm{~Hz}\right), 1.23-1.38$ (m, 3H, cyclohexyl); ${ }^{13} \mathrm{C} \mathrm{NMR} \mathrm{(100} \mathrm{MHz,} \mathrm{CDCl}_{3}$, $\delta$ ppm): 174.5, 166.3, 164.2, 161.7, 153.7, 142.7, 135.7, 131.8, 131.7, 127.7, 126.9, 121.9, 118.9, 115.9, 115.7, 112.6, 56.8, 52.1, 48.4, 30.5, 25.4, 24.3, 17.1; ESI-MS (m/z): $424.4[\mathrm{M}+\mathrm{H}]^{+}$; Anal. calcd. for $\mathrm{C}_{24} \mathrm{H}_{26} \mathrm{~N}_{3} \mathrm{FO}_{3}$ : C, 68.07; H, 6.19; N, 9.92. Found: C, 68.02; H, 6.15; N, 9.91.

\section{Methyl (S)-(1-cyclohexyl-2-(4-fluorophenyl)-1H-benzo[d]imidazole-5-carbonyl)valinate (6f):} Yield 92\%; 118-120 ${ }^{\circ} \mathrm{C}$; Off white solid; IR (ATR, $\left.v_{\max }, \mathrm{cm}^{-1}\right): 3407$ (N-H), 3074 (Ar-H), 2935 and $2864(\mathrm{C}-\mathrm{H}), 1721(\mathrm{C}=\mathrm{O}$ of ester), $1654(\mathrm{C}=\mathrm{O}$ of amide), $1614(\mathrm{C}=\mathrm{N}), 1581(\mathrm{C}=\mathrm{C}), 1265(\mathrm{C}$ O), 1232 (C-F); ${ }^{1} \mathrm{H}$ NMR (400 MHz, $\mathrm{CDCl}_{3}, \delta \mathrm{ppm}$ ): 8.52 (d, $1 \mathrm{H}$, amide $\mathrm{N}-\mathrm{H}, J=7.6 \mathrm{~Hz}$ ), 8.20 (d, 1H, Ar-H, $J=1.2 \mathrm{~Hz}), 7.90$ (d, 1H, Ar-H, J=8.8 Hz), 7.74-7.76 (m, 1H, Ar-H), 7.71-7.73 (m, 2H, Ar-H), 7.42-7.46 (m, 2H, Ar-H), 4.29-4.32 (m, 1H, chiral CH), 4.26-4.28 (m, 1H, N-CH), 3.79 (s, 3H, $\mathrm{OCH}_{3}$ ), 2.25-2.33 (m, 2H, cyclohexyl), 2.20-2.25 (m, 1H, C-H of isopropyl), 1.84-1.90 (m, 4H, cyclohexyl), 1.63-1.66 (m, 1H, cyclohexyl), 1.24-1.41 (m, 3H, cyclohexyl), 0.97-1.01 (m, 6H, diastereotopic $\left.\mathrm{CH}_{3}\right) ;{ }^{13} \mathrm{C}$ NMR (100 $\left.\mathrm{MHz} \mathrm{CDCl}_{3}, \delta \mathrm{ppm}\right): 174.4$, 166.9, 164.2, 161.7, 154.6, $142.8,135.7,131.8,131.7,127.5,122.5,121.6,118.7,115.9,115.7,112.4,58.6,56.3,52.3,30.5$, 29.6, 25.5, 24.4, 19.4, 18.8; ESI-MS (m/z): $452.4[\mathrm{M}+\mathrm{H}]^{+}$; Anal. calcd. for $\mathrm{C}_{26} \mathrm{H}_{30} \mathrm{~N}_{3} \mathrm{FO}_{3}$ : C, 69.16; H, 6.70; N, 9.31. Found: C, 69.13; H, 6.69; N, 9.32.

Methyl (S)-(1-cyclohexyl-2-(4-fluorophenyl)-1H-benzo[d]imidazole-5-carbonyl)leucinate (6g): Yield 96\%, 102-104 ${ }^{\circ} \mathrm{C}$; Off white solid; IR (ATR, $v_{\max }, \mathrm{cm}^{-1}$ ): 3409 (N-H), 3071 (Ar-H), 2934 
and $2865(\mathrm{C}-\mathrm{H}), 1717(\mathrm{C}=\mathrm{O}$ of ester), $1654(\mathrm{C}=\mathrm{O}$ of amide), $1614(\mathrm{C}=\mathrm{N}), 1579(\mathrm{C}=\mathrm{C}), 1265(\mathrm{C}-$ O), 1231 (C-F); ${ }^{1} \mathrm{H}$ NMR (400 MHz, $\mathrm{CDCl}_{3}, \delta \mathrm{ppm}$ ): 8.59 (d, 1H, amide N-H, J=7.6 Hz), 8.3 (s, 1H, Ar-H), 7.93 (d, 1H, Ar-H, J = 8.4 Hz), 7.84 (d, 2H, Ar-H, $J=8.4$ Hz), 7.72-7.75 (m, 2H, ArH), 7.42-7.46 (m, 2H, Ar-H), 4.47-4.52 (m, 1H, chiral CH), 4.20-4.26 (m, 1H, N-CH), 3.79 (s, 3H, $\left.\mathrm{OCH}_{3}\right), 2.24-2.32(\mathrm{~m}, 2 \mathrm{H}$, cyclohexyl), 1.59-1.92 (m, 8H, cyclohexyl, isobutyl $\mathrm{CH}$ and diastereotopic $\left.\mathrm{CH}_{2}\right), 1.23-1.41$ (m, 3H, cyclohexyl), $0.95\left(\mathrm{~d}, 3 \mathrm{H}\right.$, diastereotopic $\left.\mathrm{CH}_{3}, J=6.4 \mathrm{~Hz}\right)$ $0.91\left(\mathrm{~d}, 3 \mathrm{H}\right.$, diastereotopic $\left.\mathrm{CH}_{3}, J=6.4 \mathrm{~Hz}\right) ;{ }^{13} \mathrm{C} \mathrm{NMR}\left(100 \mathrm{MHz}, \mathrm{CDCl}_{3}, \delta \mathrm{ppm}\right): 174.4,166.7$, 164.2, 161.7, 153.7, 142.6, 135.6, 131.8, 131.7, 127.7, 126.8, 121.9, 118.9, 115.9, 115.7, 112.6, 56.8, 52.1, 50.9, 30.5, 25.4, 24.6, 24.3, 22.9, 21.2; ESI-MS (m/z): $466.4[\mathrm{M}+\mathrm{H}]^{+}$; Anal. calcd. for $\mathrm{C}_{27} \mathrm{H}_{32} \mathrm{~N}_{3} \mathrm{FO}_{3}$ : C, 69.66; H, 6.93; N, 9.03. Found: C, 69.64; H, 6.91; N, 9.04.

\section{Methyl (S)-(1-cyclohexyl-2-(4-fluorophenyl)-1H-benzo[d]imidazole-5-carbonyl)- tryptophanate}

(6h): Yield 96\%; Mp 78-80 ${ }^{\circ} \mathrm{C}$; Off white solid; FT IR (ATR, vmax, $\mathrm{cm}^{-1}$ ): 3409 (N-H), 3056 (Ar-H), 2933 and $2858(\mathrm{C}-\mathrm{H}), 1720(\mathrm{C}=\mathrm{O}$ of ester), $1641(\mathrm{C}=\mathrm{O}$ of amide), $1614(\mathrm{C}=\mathrm{N}), 1527$ $(\mathrm{C}=\mathrm{C}), 1296$ (C-O), 1230 (C-F); ${ }^{1} \mathrm{H}$ NMR (400 MHz, $\left.\mathrm{CDCl}_{3}, \delta \mathrm{ppm}\right): 10.79$ (s, 1H, indole-NH), $8.52(\mathrm{~d}, 1 \mathrm{H}$, amide-NH, $J=7.6 \mathrm{~Hz}), 8.2(\mathrm{~d}, 1 \mathrm{H}, \mathrm{Ar}-\mathrm{H}, J=1.2 \mathrm{~Hz}), 7.90$ (d, 1H, Ar-H, $J=8.8 \mathrm{~Hz})$, 7.71-7.76 (m, 3H, Ar-H), 7.62 (d, 1H, Ar-H, J=8.0 Hz), 7.44 (m, 2H, Ar-H, J = 8.8 Hz), 7.32 (d, $1 \mathrm{H}, \operatorname{Ar}-\mathrm{H}, J=8.0 \mathrm{~Hz}), 7.22(\mathrm{~d}, 1 \mathrm{H}, \mathrm{Ar}-\mathrm{H}, J=2.0 \mathrm{~Hz}), 7.03-7.07$ (m, 1H, Ar-H); 6.95-6.99 (m, 1H, Ar-H); 4.63-4.68 (m, 1H, chiral C-H), 4.19-4.25 (m, 1H, -NC-H), 3.79 (s, 3H, $\left.\mathrm{OCH}_{3}\right), 3.33-3.38$ (dd, $1 \mathrm{H}$, indole $\mathrm{CH}_{2}, J=4.2$ and $14.6 \mathrm{~Hz}$ ), 3.23-3.29 (dd, $1 \mathrm{H}$, indole $\mathrm{CH}_{2}, J=9.2$ and $14.4 \mathrm{~Hz}$ ), 2.22-2.31 (m, 2H, cyclohexyl), 1.82-1.92 (m, 4H, cyclohexyl), 1.62-1.65 (m, 1H, cyclohexyl), 1.26-1.40 (m, 3H, cyclohexyl); ${ }^{13} \mathrm{C}$ NMR (100 MHz, $\left.\mathrm{CDCl}_{3}, \delta \mathrm{ppm}\right): 173.8,166.3,164.2,161.7$, 153.7, 142.6, 136.0, 135.6, 131.8, 131.7, 128.0, 127.3, 126.9, 125.9, 123.5, 121.7, 120.8, 118.7, 118.2, 115.8, 115.7, 112.6, 111.3, 110.7, 56.8, 54.1, 51.9, 30.5, 26.8, 25.4, 24.3; ESI-MS ( $\mathrm{m} / \mathrm{z})$ : 539.22 [M+H] ${ }^{+}$; Anal. calcd. for $\mathrm{C}_{32} \mathrm{H}_{31} \mathrm{~N}_{4} \mathrm{FO}_{3}$ : C, 71.36; H, 5.80; N, 10.40. Found: C, 71.37; $\mathrm{H}$, $5.78 ; \mathrm{N}, 10.36$.

Methyl (S)-(2-(2-chloro-6-fluorophenyl)-1-cyclohexyl-1H-benzo[d]imidazole-5-carbonyl)alaninate (6i): Yield 88\%; Mp 104-106 ${ }^{\circ} \mathrm{C}$; Off white solid; IR (ATR, vmax $\mathrm{cm}^{-1}$ ): 2928 and 2863 $(\mathrm{C}-\mathrm{H}), 1738(\mathrm{C}=\mathrm{O}$ of ester), $1642(\mathrm{C}=\mathrm{O}$ of amide), $1614(\mathrm{C}=\mathrm{N}), 1532(\mathrm{C}=\mathrm{C}), 1159(\mathrm{C}-\mathrm{O}), 781(\mathrm{C}-$ $\mathrm{C}-\mathrm{Cl}) ;{ }^{1} \mathrm{H}$ NMR (400 MHz, $\left.\mathrm{CDCl}_{3}, \delta \mathrm{ppm}\right): 8.27$ (s, 1H, Ar-H), 7.86 (d, 1H, Ar-H, J = 8.0 Hz), $7.70(\mathrm{~d}, 1 \mathrm{H}, \mathrm{Ar}-\mathrm{H}, J=8.0 \mathrm{~Hz}), 7.47-7.51(\mathrm{~m}, 1 \mathrm{H}, \mathrm{Ar}-\mathrm{H}), 7.37-7.39$ (m, 1H, Ar-H), 7.17 (t, 1H, 
Ar-H, $J=8.0 \mathrm{~Hz}$ ), 6.90 (bs, 1H, amide N-H), 4.83-4.86 (m, 1H, chiral CH), 3.83-3.87 (m, 1H, N$\mathrm{CH}), 3.79$ (s, 3H, $\left.\mathrm{OCH}_{3}\right), 1.91-2.18$ (m, 6H, cyclohexyl), 1.55 (d, 3H, $\left.\mathrm{CH}_{3}, J=8.0 \mathrm{~Hz}\right), 1.27-1.31$ (m, 4H, cyclohexyl); ${ }^{13} \mathrm{C} \mathrm{NMR}\left(100 \mathrm{MHz}, \mathrm{CDCl}_{3}, \delta \mathrm{ppm}\right): 173.7,167.2,162.7,160.2,146.7$, 143.6, 136.1, 135.7, 132.4, 132.3, 128.2, 125.6, 122.3, 119.4, 114.5, 114.3, 112.4, 58.0, 52.5, 48.6, 31.5, 25.9, 25.1, 18.6; ESI-MS $(\mathrm{m} / \mathrm{z}): 458.2[\mathrm{M}+\mathrm{H}]^{+}, 460.2[\mathrm{M}+2+\mathrm{H}]^{+}$; Anal. calcd. for $\mathrm{C}_{24} \mathrm{H}_{25} \mathrm{~N}_{3} \mathrm{ClFO}_{3}$ : C, 62.95; H, 5.50; N, 9.18. Found: C, 62.92; H, 5.48; N, 9.15.

Methyl (S)-(2-(2-chloro-6-fluorophenyl)-1-cyclohexyl-1H-benzo[d]imidazole-5-carbonyl)valinate (6j): Yield 86\%; Mp 58-60 ${ }^{\circ} \mathrm{C}$; Off white solid; IR (ATR, $v_{\max }, \mathrm{cm}^{-1}$ ): $3362(\mathrm{O}-\mathrm{H}), 3073$ (Ar-H), 2947 and $2861(\mathrm{C}-\mathrm{H}), 1724(\mathrm{C}=\mathrm{O}$ of ester), $1644(\mathrm{C}=\mathrm{O}$ of amide), $1621(\mathrm{C}=\mathrm{N}), 1574$ $(\mathrm{C}=\mathrm{C}), 1297$ (C-O), $1246(\mathrm{C}-\mathrm{F}) ;{ }^{1} \mathrm{H}$ NMR (400 MHz, $\mathrm{CDCl}_{3}, \delta$ ppm): 8.61 (d, 1H, amide N-H, $J$ $=8.0 \mathrm{~Hz}), 8.34(\mathrm{~s}, 1 \mathrm{H}, \mathrm{Ar}-\mathrm{H}), 7.97(\mathrm{~d}, 1 \mathrm{H}, \mathrm{Ar}-\mathrm{H}, J=8.4 \mathrm{~Hz}), 7.87$ (d, 1H, Ar-H, J=8.8 Hz), 7.717.77 (m, 1H, Ar-H), $7.62(\mathrm{~m}, 1 \mathrm{H}, \mathrm{Ar}-\mathrm{H}), 7.49-7.54(\mathrm{~m}, 1 \mathrm{H}, \mathrm{Ar}-\mathrm{H}), 4.29-4.32(\mathrm{~m}, 1 \mathrm{H}$, chiral CH), 4.26-4.28 (m, 1H, N-CH), 3.79 (s, 3H, $\left.\mathrm{OCH}_{3}\right), 2.25-2.33(\mathrm{~m}, 2 \mathrm{H}$, cyclohexyl), 2.20-2.25 (m, 1H, C-H of isopropyl), 1.84-1.90 (m, 4H, cyclohexyl), 1.63-1.66 (m, 1H, cyclohexyl), 1.24-1.41 (m, $3 \mathrm{H}$, cyclohexyl), 0.97-1.01 (m, 6H, diastereotopic $\left.\left.\mathrm{CH}_{3}\right) ;{ }^{13} \mathrm{C} \mathrm{NMR} \mathrm{(100} \mathrm{MHz}, \mathrm{CDCl}_{3}, \delta \mathrm{ppm}\right)$ : $174.4,166.4,162.9,160.5,146.8,143.7,136.5,132.3,125.5,124.5,122.9,114.4,114.2$, 111.9, 58.7, 56.6, 52.4, 30.5, 29.6, 25.5, 24.4, 19.4, 18.9; ESI-MS (m/z): $486.4[\mathrm{M}+\mathrm{H}]^{+}, 488.4[\mathrm{M}+2+\mathrm{H}]^{+}$; Anal. calcd. for $\mathrm{C}_{26} \mathrm{H}_{29} \mathrm{~N}_{3} \mathrm{ClFO}_{3}$ : C, 64.26; H, 6.02; N, 8.65. Found: C, 64.20; H, 5.99; N, 8.61.

\section{Methyl (S)-(2-(2-chloro-6-fluorophenyl)-1-cyclohexyl-1H-benzo[d]imidazole-5-carbonyl)-} leucinate (6k): Yield 96\%; Mp 54-56 ${ }^{\circ} \mathrm{C}$; Off white solid; IR (ATR, vmax $\mathrm{cm}^{-1}$ ): $3355(\mathrm{O}-\mathrm{H}), 3080$ $(\mathrm{Ar}-\mathrm{H}), 2948$ and $2864(\mathrm{C}-\mathrm{H}), 1722(\mathrm{C}=\mathrm{O}$ of ester), $1643(\mathrm{C}=\mathrm{O}$ of amide $), 1620(\mathrm{C}=\mathrm{N}), 1571$ (C=C), 1299 (C-O), 1249 (C-F); ${ }^{1} \mathrm{H}$ NMR (400 MHz, $\mathrm{CDCl}_{3}, \delta$ ppm): 12.51 (s, 1H, CO $\left.2 \mathrm{H}\right), 8.61$ (d, 1H, amide N-H, J = 8.0 Hz), 8.34 (s, 1H, Ar-H), 7.97 (d, 1H, Ar-H, J=8.4 Hz), 7.87 (d, 1H, Ar-H, $J=8.8$ Hz), 7.71-7.77 (m, 1H, Ar-H), 7.62 (m, 1H, Ar-H), 7.49-7.54 (m, 1H, Ar-H), 4.47$4.51\left(\mathrm{~m}, 1 \mathrm{H}\right.$, chiral C-H), 3.84-3.90 (m, 1H, N-CH), $3.79\left(\mathrm{~s}, 3 \mathrm{H}, \mathrm{OCH}_{3}\right), 2.12-2.21$ (m, 2H, cyclohexyl), 1.60-1.84 (m, 8H, cyclohexyl, isobutyl $\mathrm{CH}$ and diastereotopic $\mathrm{CH}_{2}$ ), 1.24-1.29 (m, $3 \mathrm{H}$, cyclohexyl), 0.94 (d, 3H, diastereotopic $\left.\mathrm{CH}_{3}, J=6.4 \mathrm{~Hz}\right), 0.90$ (d, 3H, diastereotopic $\mathrm{CH}_{3}, J$ $=6.4 \mathrm{~Hz}) ;{ }^{13} \mathrm{C} \mathrm{NMR}\left(100 \mathrm{MHz}, \mathrm{CDCl}_{3}, \delta \mathrm{ppm}\right): 174.4,166.4,162.8,160.5,146.8,143.7,136.5$, $132.3,125.5,124.5,124.0,122.9,114.5,114.3,111.9,56.6,50.9,52.1,30.5,25.5,24.6,24.3,23.1$, 
21.6; ESI-MS (m/z): $500.2[\mathrm{M}+\mathrm{H}]^{+}, 502.2[\mathrm{M}+2+\mathrm{H}]^{+}$; Anal. calcd. for $\mathrm{C}_{27} \mathrm{H}_{31} \mathrm{~N}_{3} \mathrm{ClFO}_{3}: \mathrm{C}, 64.86$; H, 6.25; N, 8.40. Found: C, 64.85; H, 6.23; N, 8.42.

Methyl

(S)-(2-(2-chloro-6-fluorophenyl)-1-cyclohexyl-1H-benzo[d]imidazole-5-carbonyl)tryptophanate (6l): Yield 97\%; Mp 84-86 ${ }^{\circ} \mathrm{C}$; Off white solid; FT IR (ATR, $\left.v_{\max }, \mathrm{cm}^{-1}\right)$ : $3409(\mathrm{~N}-$ $\mathrm{H}), 3056(\mathrm{Ar}-\mathrm{H}), 2937$ and $2858(\mathrm{C}-\mathrm{H}), 1724(\mathrm{C}=\mathrm{O}$ of ester), $1641(\mathrm{C}=\mathrm{O}$ of amide), $1620(\mathrm{C}=\mathrm{N})$, 1573 (C=C), 1299 (C-O), 1251 (C-F); ${ }^{1} \mathrm{H}$ NMR (400 MHz, CDCl $3, \delta$ ppm): 10.80 (s, 1H, indoleNH), 8.67 (d, 1H, amide N-H, $J=7.6 \mathrm{~Hz}), 8.27$ (s, 1H, Ar-H), 7.95 (d, 1H, Ar-H, $J=8.4 \mathrm{~Hz})$, 7.71-7.80 (m, 2H, Ar-H), 7.60-7.63 (m, 2H, Ar-H), 7.49-7.53 (m, 1H, Ar-H), 7.32 (d, 1H, Ar-H, J $=8.0 \mathrm{~Hz}), 7.23(\mathrm{~s}, 1 \mathrm{H}, \mathrm{Ar}-\mathrm{H}), 7.04-7.08(\mathrm{~m}, 1 \mathrm{H}, \mathrm{Ar}-\mathrm{H}), 6.98-7.01(\mathrm{~m}, 1 \mathrm{H}, \mathrm{Ar}-\mathrm{H}), 4.67-4.72(\mathrm{~m}$, 1H, chiral C-H), 3.83-3.89 (m, 1H, N-CH), 3.79 (s, 3H, $\left.\mathrm{OCH}_{3}\right), 3.22-3.28\left(\mathrm{~m}, 2 \mathrm{H}\right.$, indolyl $\left.\mathrm{CH}_{2}\right)$, 2.07-2.18 (m, 2H, cyclohexyl), 1.79-1.90 (m, 4H, cyclohexyl), 1.59-1.61 (m, 1H, cyclohexyl), 1.17-1.28 (m, 3H, cyclohexyl); ${ }^{13} \mathrm{C}$ NMR (100 MHz, $\mathrm{CDCl}_{3}, \delta$ ppm): 173.6, 166.6, 161.9, 159.5, $145.8,142.8,136.2,135.1,134.8,133.6,128.1,127.2$, 125.9, 123.6, 122.5, 120.9, 119.2, 118.4, 118.1, 114.9, 112.3, 111.5, 110.5, 57.2, 53.9, 52.2, 30.8, 26.6, 25.3, 24.3; ESI-MS (m/z): 573.3 $[\mathrm{M}+\mathrm{H}]^{+}, 575.3[\mathrm{M}+2+\mathrm{H}]^{+}$; Anal. calcd. for $\mathrm{C}_{32} \mathrm{H}_{30} \mathrm{~N}_{4} \mathrm{ClFO}_{3}: \mathrm{C}, 67.07 ; \mathrm{H}, 5.28 ; \mathrm{N}, 9.78$. Found: C, 67.05; H, 5.27; N, 9.76.

\section{Procedure for the synthesis of benzimidazole monopeptides (7a-l)}

To a stirred clear solution of $\mathbf{6 a - 1}(0.01 \mathrm{~mol})$ in $20 \mathrm{~mL}$ of THF:water $(2: 1)$ mixture, $\mathrm{LiOH}_{\mathrm{H}} \mathrm{O}$ ( 0.015 mol, 1.5 equiv.) was added at $0{ }^{\circ} \mathrm{C}$. The stirring was continued at this temperature for $4 \mathrm{~h}$. After completion of the reaction (monitored by TLC, hexane: ethyl acetate $(4: 6, \mathrm{v} / \mathrm{v})$ ), the reaction mass was quenched to crushed ice, acidified with dilute $\mathrm{HCl}$. The resulting solid was washed with water and dried. The solid was subjected to column chromatography to obtain pure benzimidazole monopeptides.

(S)-(1-Cyclohexyl-2-(4-methoxyphenyl)-1H-benzo[d]imidazole-5-carbonyl)alanine (7a): Yield 71\%; Mp 278-280 C; Off white solid; FT IR (ATR, $\left.v_{\max }, \mathrm{cm}^{-1}\right): 3406$ (O-H), 3078 (Ar-H), 2935 and $2854(\mathrm{C}-\mathrm{H}), 1716(\mathrm{C}=\mathrm{O}$ of acid), $1654(\mathrm{C}=\mathrm{O}$ of amide), $1612(\mathrm{C}=\mathrm{N}), 1577(\mathrm{C}=\mathrm{C}), 1029(\mathrm{C}$ O); ${ }^{1} \mathrm{H}$ NMR (400 MHz, DMSO- $d_{6}, \delta$ ppm): 12.44 (s, $1 \mathrm{H}, \mathrm{CO}_{2} \mathrm{H}$ ), 8.65 (d, $1 \mathrm{H}$, amide N-H, $J=7.2$ 
$\mathrm{Hz}), 8.27(\mathrm{~d}, 1 \mathrm{H}, \mathrm{Ar}-\mathrm{H}, J=1.2 \mathrm{~Hz}), 7.90(\mathrm{~d}, 1 \mathrm{H}, \mathrm{Ar}-\mathrm{H}, J=8.4 \mathrm{~Hz}), 7.79-7.82(\mathrm{dd}, 1 \mathrm{H}, \mathrm{Ar}-\mathrm{H}, J=$ 1.6 and $7.2 \mathrm{~Hz}), 7.61(\mathrm{~d}, 1 \mathrm{H}, \mathrm{Ar}-\mathrm{H}, J=8.8 \mathrm{~Hz}), 7.15$ (d, 1H, Ar-H, $J=9.2 \mathrm{~Hz}), 4.42-4.49$ (m, 1H, chiral $\mathrm{CH}), 4.26-4.32(\mathrm{~m}, 1 \mathrm{H}, \mathrm{N}-\mathrm{CH}), 3.86\left(\mathrm{~s}, 3 \mathrm{H}, \mathrm{OCH}_{3}\right), 2.25-2.33$ (m, 2H, cyclohexyl), 1.841.92 (m, 4H, cyclohexyl), 1.63-1.66 (m, 1H, cyclohexyl), 1.42-1.44 (d, 3H, $\left.\mathrm{CH}_{3}, J=7.2 \mathrm{~Hz}\right), 1.23-$ 1.39 (m, 3H, cyclohexyl); ${ }^{13} \mathrm{C}$ NMR (100 MHz, DMSO- $d_{6}, \delta$ ppm): 174.4, 166.4, 160.4, 154.7, $142.8,135.7,130.8,127.5,122.5,121.6,118.7,114.2,112.4,56.7,55.3,48.2,30.5,25.5,24.4$, 16.9; ESI-MS (m/z): $422.4[\mathrm{M}+\mathrm{H}]^{+}$; Anal. calcd. for $\mathrm{C}_{24} \mathrm{H}_{27} \mathrm{~N}_{3} \mathrm{O}_{4}$ : C, 68.39; H, 6.46; N, 9.97. Found: C, 68.35; H, 6.47; N, 9.94.

(S)-(1-Cyclohexyl-2-(4-methoxyphenyl)-1H-benzo[d]imidazole-5-carbonyl)valine (7b): Yield 50\%; Mp 194-196 C; Off white solid; FT IR (ATR, $v_{\max }, \mathrm{cm}^{-1}$ ): 3409 (O-H), 3379 and 3409 (NH), 3100 (Ar-H), 2935 and $2850(\mathrm{C}-\mathrm{H}), 1712(\mathrm{C}=\mathrm{O}$ of acid), $1650(\mathrm{C}=\mathrm{O}$ of amide), $1612(\mathrm{C}=\mathrm{N}), 1581$ $(\mathrm{C}=\mathrm{C}), 1029(\mathrm{C}-\mathrm{O}) ;{ }^{1} \mathrm{H}$ NMR (400 MHz, DMSO- $\left.d_{6}, \delta \mathrm{ppm}\right): 8.33$ (d, 1H, amide NH, $J=8.0 \mathrm{~Hz}$ ); 8.27 (d, 1H, Ar-H, $J=1.2 \mathrm{~Hz}$ ), 7.89 (d, 1H, Ar-H, $J=8.8 \mathrm{~Hz}$ ), 7.78-7.80 (dd, 1H, Ar-H, $J=1.6$ and $8.4 \mathrm{~Hz}), 7.61$ (d, 2H, Ar-H, $J=8.8 \mathrm{~Hz}), 7.15$ (d, 2H, Ar-H, $J=8.8 \mathrm{~Hz}), 4.26-4.32(\mathrm{~m}, 2 \mathrm{H}, \mathrm{N}-$ $\mathrm{CH}$ and chiral $\mathrm{CH}), 3.86\left(\mathrm{~s}, 3 \mathrm{H}, \mathrm{OCH}_{3}\right), 2.19-2.33$ (m, 3H, $\mathrm{CH}$ and cyclohexyl), 1.84-1.90 (m, 4H, cyclohexyl), 1.63-1.66 (m, 1H, cyclohexyl), 1.23-1.41 (m, 3H, cyclohexyl), 0.97-1.01 (m, 6H, diastereotopic $\left.\mathrm{CH}_{3}\right) ;{ }^{13} \mathrm{C}$ NMR (100 MHz, DMSO- $d_{6}, \delta$ ppm): 174.3, 166.9, 160.4, 154.6, 142.7, 135.7, 130.8, 127.8, 122.5, 121.7, 118.8, 114.2, 112.4, 58.6, 56.7, 55.3, 30.5, 29.6, 25.5, 24.4, 19.4, 18.8; ESI-MS (m/z): $450.4[\mathrm{M}+\mathrm{H}]^{+}$; Anal. calcd. for $\mathrm{C}_{26} \mathrm{H}_{31} \mathrm{~N}_{3} \mathrm{O}_{4}$ : C, 69.47; H, 6.95; N, 9.35. Found: C, 69.45; H, 6.92; N, 9.37.

(S)-(1-Cyclohexyl-2-(4-methoxyphenyl)-1H-benzo[d]imidazole-5-carbonyl)leucine (7c): Yield 66\%; Mp: 224-226 C; Off white solid; FT IR (ATR, $v_{\max }, \mathrm{cm}^{-1}$ ): 3413 (O-H), 3074 (Ar-H), 2935 and $2862(\mathrm{C}-\mathrm{H}), 1712(\mathrm{C}=\mathrm{O}$ of acid $), 1650(\mathrm{C}=\mathrm{O}$ of amide), $1612(\mathrm{C}=\mathrm{N}), 1577(\mathrm{C}=\mathrm{C}), 1029(\mathrm{C}-$ O); ${ }^{1} \mathrm{H}$ NMR (400 MHz, DMSO- $d_{6}, \delta$ ppm): 8.33 (d, $1 \mathrm{H}$, amide NH, $J=6.8 \mathrm{~Hz}$ ), 8.23 (s, $1 \mathrm{H}, \mathrm{Ar}-$ H), $7.88(\mathrm{~d}, 1 \mathrm{H}, \mathrm{Ar}-\mathrm{H}, J=8.4 \mathrm{~Hz}), 7.78(\mathrm{~d}, 1 \mathrm{H}, \mathrm{Ar}-\mathrm{H}, J=8.4 \mathrm{~Hz}), 7.60(\mathrm{~d}, 1 \mathrm{H}, \mathrm{Ar}-\mathrm{H}, J=8.4 \mathrm{~Hz})$, $7.14(\mathrm{~d}, 1 \mathrm{H}, \mathrm{Ar}-\mathrm{H}, J=8.8 \mathrm{~Hz}), 4.37-4.40(\mathrm{~m}, 1 \mathrm{H}$, chiral $\mathrm{CH}), 4.25-4.31(\mathrm{~m}, 1 \mathrm{H}, \mathrm{C}-\mathrm{NH}), 3.86$ (s, $\left.3 \mathrm{H}, \mathrm{OCH}_{3}\right), 2.24-2.33(\mathrm{~m}, 2 \mathrm{H}$, cyclohexyl), 1.83-1.90 (m, 4H, cyclohexyl), 1.62-1.76 (m, 4H, isobutyl $\mathrm{CH}, \mathrm{CH}_{2}$ and cyclohexyl), 1.24-1.41 (m, 3H, cyclohexyl), 0.89-0.92 (m, 6H, diastereotopic $\left.\mathrm{CH}_{3}\right) ;{ }^{13} \mathrm{C}$ NMR (100 MHz, DMSO- $d_{6}, \delta$ ppm): 174.4, 166.4, 160.4, 154.6, 142.8, 135.6, 130.8, 128.0, 122.5, 121.5, 118.6, 114.2, 112.4, 56.6, 55.3, 30.5, 29.6, 25.5, 24.6, 23.0, 21.6, 
18.9; ESI-MS (m/z): $464.4[\mathrm{M}+\mathrm{H}]^{+}$; Anal. calcd. for $\mathrm{C}_{27} \mathrm{H}_{33} \mathrm{~N}_{3} \mathrm{O}_{4}$ : C, 69.95; H, 7.18; N, 9.06.

2 Found: C, 69.96; H, 7.15; N, 9.04.

(S)-(1-Cyclohexyl-2-(4-methoxyphenyl)-1H-benzo[d]imidazole-5-carbonyl)tryptophan (7d):

Yield 99\%, Mp: $172-174^{\circ} \mathrm{C}$; Off white to pale brown solid; FT IR (ATR, $v_{\max }, \mathrm{cm}^{-1}$ ): $3406(\mathrm{O}-\mathrm{H})$, 3055 (Ar-H), 2933 and 2856 (C-H), 1720 (C=O of acid), 1643 (C=O of amide), $1612(\mathrm{C}=\mathrm{N}), 1577$ $(\mathrm{C}=\mathrm{C}), 1178(\mathrm{C}-\mathrm{O}) ;{ }^{1} \mathrm{H}$ NMR (400 MHz, DMSO- $\left.d_{6}, \delta \mathrm{ppm}\right): 10.81$ (s, 1H, indole NH), 8.62 (d, $1 \mathrm{H}$, amide NH, $J=7.6 \mathrm{~Hz}), 8.20$ (d, 1H, Ar-H, $J=1.6 \mathrm{~Hz}), 7.88$ (d, 1H, Ar-H, $J=8.4$ Hz), 7.72$7.75(\mathrm{dd}, 1 \mathrm{H}, \mathrm{Ar}-\mathrm{H}, J=8.4$ and $1.6 \mathrm{~Hz}), 7.59-7.63(\mathrm{~m}, 3 \mathrm{H}, \mathrm{Ar}-\mathrm{H}), 7.32(\mathrm{~d}, 1 \mathrm{H}, \mathrm{Ar}-\mathrm{H}, J=8.0 \mathrm{~Hz})$, $7.23(\mathrm{~d}, 1 \mathrm{H}, \mathrm{Ar}-\mathrm{H}, J=2.0 \mathrm{~Hz}), 7.15$ (d, 2H, Ar-H, $J=8.8 \mathrm{~Hz}), 7.04-7.08$ (m, 1H, Ar-H), 6.97-7.01 (m, 1H, Ar-H), 4.66-4.72 (m, 1H, chiral CH), 4.25-4.31 (m, 1H, C-NH), 3.86 (s, 3H, $\left.\mathrm{OCH}_{3}\right), 2.23-$ 2.29 (m, 2H, cyclohexyl), 1.83-1.89 (m, 4H, cyclohexyl), 1.62-1.65 (m, 1H, cyclohexyl), 1.251.41 (m, 3H, cyclohexyl); ${ }^{13} \mathrm{C}$ NMR (100 MHz, DMSO- $d_{6}, \delta$ ppm): 173.7, 166.6, 160.4, 154.6, 142.6, 136.1, 135.6, 130.9, 127.6, 127.1, 125.76, 123.6, 121.6, 120.9, 118.5, 118.4, 118.1, 114.2, 112.5, 111.4, 110.5, 56.7, 55.3, 53.7, 30.5, 26.6, 25.5, 24.3; ESI-MS (m/z): $537.5[\mathrm{M}+\mathrm{H}]^{+}$; Anal. calcd. for $\mathrm{C}_{32} \mathrm{H}_{32} \mathrm{~N}_{4} \mathrm{O}_{4}$ : C, 71.62; H, 6.01; N, 10.44. Found: C, 71.59; H, 6.02; N, 10.41.

(S)-(1-Cyclohexyl-2-(4-fluorophenyl)-1H-benzo[d]imidazole-5-carbonyl)alanine (7e): Yield 75\%; Mp 272-274 ${ }^{\circ}$; Off white solid; IR (ATR, $\left.v_{\max }, \mathrm{cm}^{-1}\right): 3411(\mathrm{O}-\mathrm{H}), 3071(\mathrm{Ar}-\mathrm{H}), 2932$ and $2861(\mathrm{C}-\mathrm{H}), 1706(\mathrm{C}=\mathrm{O}$ of acid), $1653(\mathrm{C}=\mathrm{O}$ of amide), $1614(\mathrm{C}=\mathrm{N}), 1578(\mathrm{C}=\mathrm{C}), 1265(\mathrm{C}-\mathrm{O})$, 1230 (C-F); ${ }^{1} \mathrm{H}$ NMR (400 MHz, DMSO-d,$\delta$ ppm): 8.63 (d, $1 \mathrm{H}$, amide N-H, J=7.2 Hz), 8.29 (s, 1H, Ar-H), 7.93 (d, 1H, Ar-H, J=8.8 Hz), 7.83 (d, 1H, Ar-H, J=8.8 Hz), 7.71-7.75 (m, 2H, ArH), 7.42-7.46 (m, 2H, Ar-H), 4.41-4.48 (m, 1H, chiral CH), 4.20-4.26 (m, 1H, N-CH), 2.24-2.32 (m, 2H, cyclohexyl), 1.83-1.93 (m, 4H, cyclohexyl), 1.63-1.66 (m, 1H, cyclohexyl), 1.42-1.44 (d, $\left.3 \mathrm{H}, \mathrm{CH}_{3}, J=7.2 \mathrm{~Hz}\right), 1.23-1.38$ (m, 3H, cyclohexyl); ${ }^{13} \mathrm{C}$ NMR (100 MHz, DMSO-d,$\left.\delta \mathrm{ppm}\right)$ : $174.5,166.3,164.2,161.7,153.7,142.7,135.7,131.8,131.7,127.7,126.9,121.9,118.9,115.9$, 115.7, 112.6, 56.8, 48.4, 30.5, 25.4, 24.3, 17.1; ESI-MS $(\mathrm{m} / \mathrm{z}): 410.4[\mathrm{M}+\mathrm{H}]^{+}$; Anal. calcd. for $\mathrm{C}_{23} \mathrm{H}_{24} \mathrm{~N}_{3} \mathrm{FO}_{3}$ : C, 67.47; H, 5.91; N, 10.26. Found: C, 67.43; H, 5.88; N, 10.27.

(S)-(1-Cyclohexyl-2-(4-fluorophenyl)-1H-benzo[d]imidazole-5-carbonyl)valine (7f): Yield 89\%; 262-264 ${ }^{\circ} \mathrm{C}$; Off white solid; IR (ATR, $\left.v_{\max }, \mathrm{cm}^{-1}\right): 3407$ (O-H), $3074(\mathrm{Ar}-\mathrm{H}), 2935$ and 2864 (C-H), 1706 (C=O of acid), $1654(\mathrm{C}=\mathrm{O}$ of amide), $1614(\mathrm{C}=\mathrm{N}), 1581(\mathrm{C}=\mathrm{C}), 1265(\mathrm{C}-\mathrm{O}), 1232$ 
(C-F); ${ }^{1} \mathrm{H}$ NMR (400 MHz, DMSO- $d_{6}, \delta$ ppm): 8.52 (d, 1H, amide N-H, $J=7.6 \mathrm{~Hz}$ ), 8.20 (d, 1H, $\operatorname{Ar}-\mathrm{H}, J=1.2 \mathrm{~Hz}), 7.90(\mathrm{~d}, 1 \mathrm{H}, \mathrm{Ar}-\mathrm{H}, J=8.8 \mathrm{~Hz}), 7.74-7.76(\mathrm{~m}, 1 \mathrm{H}, \mathrm{Ar}-\mathrm{H}), 7.71-7.73$ (m, 2H, ArH), 7.42-7.46 (m, 2H, Ar-H), 4.29-4.32 (m, 1H, chiral CH), 4.26-4.28 (m, 1H, N-CH), 2.25-2.33 (m, 2H, cyclohexyl), 2.20-2.25 (m, 1H, C-H of isopropyl), 1.84-1.90 (m, 4H, cyclohexyl), 1.631.66 (m, 1H, cyclohexyl), 1.24-1.41 (m, 3H, cyclohexyl), 0.97-1.01 (m, 6H, diastereotopic $\mathrm{CH}_{3}$ ); ${ }^{13} \mathrm{C}$ NMR (100 MHz, DMSO- $d_{6}, \delta$ ppm): 174.4, 166.9, 164.2, 161.7, 154.6, 142.8, 135.7, 131.8, 131.7, 130.8, 127.5, 121.6, 118.7, 115.9, 115.7, 112.4, 58.6, 56.3, 30.5, 29.6, 25.5, 24.4, 19.4, 18.8; ESI-MS (m/z): $438.4[\mathrm{M}+\mathrm{H}]^{+}$; Anal. calcd. for $\mathrm{C}_{25} \mathrm{H}_{28} \mathrm{~N}_{3} \mathrm{FO}_{3}: \mathrm{C}, 68.63 ; \mathrm{H}, 6.45 ; \mathrm{N}, 9.60$. Found: C, 68.65; H, 6.44; N, 9.62.

(S)-(1-Cyclohexyl-2-(4-fluorophenyl)-1H-benzo[d]imidazole-5-carbonyl)leucine (7g): Yield 90\%, 244-248 ${ }^{\circ} \mathrm{C}$; Off white solid; IR (ATR, $v_{\max }, \mathrm{cm}^{-1}$ ): $3409(\mathrm{O}-\mathrm{H}), 3071(\mathrm{Ar}-\mathrm{H}), 2934$ and 2865 (C-H), 1707 (C=O of acid), 1654 (C=O of amide), $1614(\mathrm{C}=\mathrm{N}), 1579$ (C=C), $1265(\mathrm{C}-\mathrm{O}), 1231$ (C-F); ${ }^{1} \mathrm{H}$ NMR (400 MHz, DMSO- $d_{6}, \delta$ ppm): 8.59 (d, $1 \mathrm{H}$, amide N-H, $J=7.6 \mathrm{~Hz}$ ), 8.3 (s, 1H, Ar-H), 7.93 (d, 1H, Ar-H, J=8.4 Hz), 7.84 (d, 1H, Ar-H, J=8.4 Hz), 7.72-7.75 (m, 2H, Ar-H), 7.42-7.46 (m, 2H, Ar-H), 4.47-4.52 (m, 1H, chiral CH), 4.20-4.26 (m, 1H, N-CH), 2.24-2.32 (m, $2 \mathrm{H}$, cyclohexyl), 1.59-1.92 (m, 8H, cyclohexyl, isobutyl $\mathrm{CH}$ and diastereotopic $\left.\mathrm{CH}_{2}\right), 1.23-1.41$ (m, 3H, cyclohexyl), 0.95 (d, 3H, diastereotopic $\left.\mathrm{CH}_{3}, J=6.4 \mathrm{~Hz}\right) 0.91$ (d, 3H, diastereotopic $\mathrm{CH}_{3}$, $J=6.4 \mathrm{~Hz}) ;{ }^{13} \mathrm{C}$ NMR $\left(100 \mathrm{MHz}, \mathrm{DMSO}-d_{6}, \delta \mathrm{ppm}\right): 174.4,166.7,164.2,161.7,153.7,142.6$, 135.6, 131.8, 131.7, 127.7, 126.8, 121.9, 118.9, 115.9, 115.8, 112.6, 56.8, 50.9, 30.5, 25.4, 24.6, 24.3, 22.9, 21.2; ESI-MS (m/z): 450.4 [M-H]'; Anal. calcd. for $\mathrm{C}_{26} \mathrm{H}_{30} \mathrm{~N}_{3} \mathrm{FO}_{3}$ : C, 69.16; H, 6.70; N, 9.31. Found: C, 69.14; H, 6.73; N, 9.34.

(S)-(1-Cyclohexyl-2-(4-fluorophenyl)-1H-benzo[d]imidazole-5-carbonyl)tryptophan (7h): Yield 91\%; Mp 164-166 C; Off white solid; FT IR (ATR, $v_{\max }, \quad \mathrm{cm}^{-1}$ ): 3409 (O-H), $3056(\mathrm{Ar}-\mathrm{H}), 2933$ and $2858(\mathrm{C}-\mathrm{H}), 1720(\mathrm{C}=\mathrm{O}$ of acid), $1641(\mathrm{C}=\mathrm{O}$ of amide), $1614(\mathrm{C}=\mathrm{N}), 1527(\mathrm{C}=\mathrm{C}), 1296(\mathrm{C}-$ O), 1230 (C-F); ${ }^{1} \mathrm{H}$ NMR (400 MHz, DMSO-d $d_{6}, \delta$ ppm): 10.79 (s, 1H, indole-NH), 8.52 (d, 1H, amide-NH, $J=7.6 \mathrm{~Hz}$ ), 8.2 (d, 1H, Ar-H, $J=1.2 \mathrm{~Hz}$ ), 7.90 (d, 1H, Ar-H, $J=8.8 \mathrm{~Hz}$ ), 7.71-7.76 (m, 3H, Ar-H), 7.62 (d, 1H, Ar-H, J=8.0 Hz), 7.44 (m, 2H, Ar-H, J=8.8 Hz), 7.32 (d, 1H, Ar-H, $J=8.0 \mathrm{~Hz}), 7.22(\mathrm{~d}, 1 \mathrm{H}, \mathrm{Ar}-\mathrm{H}, J=2.0 \mathrm{~Hz}), 7.03-7.07$ (m, 1H, Ar-H); 6.95-6.99 (m, 1H, Ar-H); 4.63-4.68 (m, 1H, chiral C-H), 4.19-4.25 (m, 1H, -NC-H), 3.33-3.38 (dd, 1H, indole $\mathrm{CH}_{2}, J=4.2$ and 14.6 Hz), 3.23-3.29 (dd, $1 \mathrm{H}$, indole $\mathrm{CH}_{2}, J=9.2$ and $\left.14.4 \mathrm{~Hz}\right), 2.22-2.31$ (m, 2H, cyclohexyl), 
1.82-1.92 (m, 4H, cyclohexyl), 1.62-1.65 (m, 1H, cyclohexyl), 1.26-1.40 (m, 3H, cyclohexyl); ${ }^{13} \mathrm{C}$ NMR (100 MHz, DMSO- $d_{6}, \delta$ ppm): 173.8, 166.3, 164.2, 161.7, 153.7, 142.6, 136.0, 135.6, 131.8, 131.7, 128.0, 127.3, 126.9, 123.5, 121.7, 120.8, 118.7, 118.3, 118.2, 115.9, 115.7, 112.6, 111.3, 110.7, 56.8, 54.1, 30.5, 26.8, 25.4, 24.3; ESI-MS $(\mathrm{m} / \mathrm{z}): 524.22[\mathrm{M}+\mathrm{H}]^{+}$; Anal. calcd. for $\mathrm{C}_{31} \mathrm{H}_{29} \mathrm{~N}_{4} \mathrm{FO}_{3}$ : C, 70.98; H, 5.57; N, 10.68. Found: C, 70.95; H, 5.58; N, 10.66 .

(S)-(2-(2-Chloro-6-fluorophenyl)-1-cyclohexyl-1H-benzo[d]imidazole-5-carbonyl)alanine (7i): Yield 70\%; Mp 248-250 ${ }^{\circ}$; Off white solid; IR (ATR, $v_{\max }, \mathrm{cm}^{-1}$ ): $3372(\mathrm{O}-\mathrm{H}), 3078$ (Ar-H), 2948 and $2862(\mathrm{C}-\mathrm{H}), 1721(\mathrm{C}=\mathrm{O}$ of acid), $1642(\mathrm{C}=\mathrm{O}$ of amide), $1620(\mathrm{C}=\mathrm{N}), 1576(\mathrm{C}=\mathrm{C}), 1296(\mathrm{C}-$ O), $1247(\mathrm{C}-\mathrm{F}) ;{ }^{1} \mathrm{H}$ NMR (400 MHz, DMSO- $\left.d_{6}, \delta \mathrm{ppm}\right): 8.61$ (d, $1 \mathrm{H}$, amide N-H, $J=8.0 \mathrm{~Hz}$ ), 8.34 (s, 1H, Ar-H), 7.97 (d, 1H, Ar-H, $J=8.4$ Hz), 7.87 (d, 1H, Ar-H, $J=8.8$ Hz), 7.71-7.77 (m, 1H, Ar-H), 7.62 (m, 1H, Ar-H), 7.49-7.54 (m, 1H, Ar-H), 4.63-4.68 (m, 1H, chiral CH), 4.19-4.25 (m, 1H, N-CH), 2.22-2.31 (m, 2H, cyclohexyl), 1.82-1.92 (m, 4H, cyclohexyl), 1.62-1.65 (m, 1H, cyclohexyl), 1.42-1.44 (d, 3H, $\left.\mathrm{CH}_{3}, J=7.2 \mathrm{~Hz}\right), 1.26-1.40$ (m, 3H, cyclohexyl); ${ }^{13} \mathrm{C}$ NMR (100 MHz, DMSO- $d_{6}, \delta$ ppm): 174.4, 166.4, 162.8, 160.5, 146.8, 143.7, 136.5, 132.3, 132.2, 125.5, 124.5, 124.0, 122.9, 119.4, 119.2, 114.5, 114.3, 111.9, 56.7, 48.2, 30.5, 25.5, 24.4, 16.9; ESI-MS $(\mathrm{m} / z): 444.4[\mathrm{M}+\mathrm{H}]^{+}, 446.4[\mathrm{M}+2+\mathrm{H}]^{+}$; Anal. calcd. for $\mathrm{C}_{23} \mathrm{H}_{23} \mathrm{~N}_{3} \mathrm{ClFO}_{3}$ : C, 62.23; $\mathrm{H}, 5.22 ; \mathrm{N}$, 9.47. Found: C, $62.25 ; \mathrm{H}, 5.21 ; \mathrm{N}, 9.45$.

(S)-(2-(2-Chloro-6-fluorophenyl)-1-cyclohexyl-1H-benzo[d]imidazole-5-carbonyl)valine (7j): Yield 81\%; Mp 88-90 C; Off white solid; IR (ATR, vmax, $\mathrm{cm}^{-1}$ ): 3362 (O-H), 3073 (Ar-H), 2947 and $2861(\mathrm{C}-\mathrm{H}), 1724(\mathrm{C}=\mathrm{O}$ of acid), $1644(\mathrm{C}=\mathrm{O}$ of amide $), 1621(\mathrm{C}=\mathrm{N}), 1574(\mathrm{C}=\mathrm{C}), 1297(\mathrm{C}-$ O), 1246 (C-F); ${ }^{1} \mathrm{H}$ NMR (400 MHz, DMSO- $d_{6}, \delta$ ppm): 8.61 (d, $1 \mathrm{H}$, amide N-H, $J=8.0 \mathrm{~Hz}$ ), 8.34 (s, 1H, Ar-H), 7.97 (d, 1H, Ar-H, J=8.4 Hz), 7.87 (d, 1H, Ar-H, J = 8.8 Hz), 7.71-7.77 (m, 1H, Ar-H), 7.62 (m, 1H, Ar-H), 7.49-7.54 (m, 1H, Ar-H), 4.29-4.32 (m, 1H, chiral CH), 4.26-4.28 (m, 1H, N-CH), 2.25-2.33 (m, 2H, cyclohexyl), 2.20-2.25 (m, 1H, C-H of isopropyl), 1.84-1.90 (m, 4H, cyclohexyl), 1.63-1.66 (m, 1H, cyclohexyl), 1.24-1.41 (m, 3H, cyclohexyl), 0.97-1.01 (m, $6 \mathrm{H}$, diastereotopic $\left.\mathrm{CH}_{3}\right) ;{ }^{13} \mathrm{C}$ NMR (100 MHz, DMSO- $\left.d_{6}, \delta \mathrm{ppm}\right): 174.4,166.4,162.9,160.5$, $146.8,143.7,136.5,132.3,132.2,125.5,124.5,122.9,119.4,119.2,114.4,114.2,111.9$, 58.7, 56.6, 30.5, 29.6, 25.5, 24.4, 19.4, 18.9; ESI-MS (m/z): $472.4[\mathrm{M}+\mathrm{H}]^{+}, 474.4[\mathrm{M}+2+\mathrm{H}]^{+}$; Anal. calcd. for $\mathrm{C}_{25} \mathrm{H}_{27} \mathrm{~N}_{3} \mathrm{ClFO}_{3}$ : C, 63.62; H, 5.77; N, 8.90. Found: C, 63.60; H, 5.74; N, 8.91. 
2 Yield 98\%; Mp 124-126 C; Off white solid; IR (ATR, $\left.v_{\max }, \quad \mathrm{cm}^{-1}\right): 3355(\mathrm{O}-\mathrm{H}), 3080(\mathrm{Ar}-\mathrm{H})$, 2948 and $2864(\mathrm{C}-\mathrm{H}), 1722$ (C=O of acid), $1643(\mathrm{C}=\mathrm{O}$ of amide), $1620(\mathrm{C}=\mathrm{N}), 1571(\mathrm{C}=\mathrm{C}), 1299$ (C-O), 1249 (C-F); ${ }^{1} \mathrm{H}$ NMR (400 MHz, DMSO-d,$\delta$ ppm): 12.51 (s, 1H, $\left.\mathrm{CO}_{2} \mathrm{H}\right), 8.61(\mathrm{~d}, 1 \mathrm{H}$, amide N-H, $J=8.0 \mathrm{~Hz}$ ), 8.34 (s, 1H, Ar-H), 7.97 (d, 1H, Ar-H, J=8.4 Hz), 7.87 (d, 1H, Ar-H, $=8.8 \mathrm{~Hz}), 7.71-7.77(\mathrm{~m}, 1 \mathrm{H}, \mathrm{Ar}-\mathrm{H}), 7.62(\mathrm{~m}, 1 \mathrm{H}, \mathrm{Ar}-\mathrm{H}), 7.49-7.54(\mathrm{~m}, 1 \mathrm{H}, \mathrm{Ar}-\mathrm{H}), 4.47-4.51$ (m, 1H, chiral C-H), 3.84-3.90 (m, 1H, N-CH), 2.12-2.21 (m, 2H, cyclohexyl), 1.60-1.84 (m, 8H, cyclohexyl, isobutyl $\mathrm{CH}$ and diastereotopic $\left.\mathrm{CH}_{2}\right), 1.24-1.29(\mathrm{~m}, 3 \mathrm{H}$, cyclohexyl), $0.94(\mathrm{~d}, 3 \mathrm{H}$, diastereotopic $\left.\mathrm{CH}_{3}, J=6.4 \mathrm{~Hz}\right), 0.90\left(\mathrm{~d}, 3 \mathrm{H}\right.$, diastereotopic $\left.\mathrm{CH}_{3}, J=6.4 \mathrm{~Hz}\right) ;{ }^{13} \mathrm{C} \mathrm{NMR}(100 \mathrm{MHz}$, DMSO- $d_{6}, \delta$ ppm): 174.4, 166.4, 162.8, 160.5, 146.8, 143.7, 136.5, 132.3, 132.2, 125.5, 124.5, 124.0, 122.9, 119.4, 119.2, 114.5, 114.3, 111.9, 56.6, 50.9, 30.5, 25.5, 24.6, 24.3, 23.1, 21.6; ESIMS $(m / z): 485.4[\mathrm{M}+\mathrm{H}]^{+}, 487.4[\mathrm{M}+2+\mathrm{H}]^{+}$; Anal. calcd. for $\mathrm{C}_{26} \mathrm{H}_{29} \mathrm{~N}_{3} \mathrm{ClFO}_{3}: \mathrm{C}, 64.26 ; \mathrm{H}, 6.01$; N, 8.65. Found: C, 64.25; H, 6.03; N, 8.66.

\section{(S)-(2-(2-Chloro-6-fluorophenyl)-1-cyclohexyl-1H-benzo[d]imidazole-5-carbonyl)tryptophan}

(7l): Yield 97\%; Mp 182-184 C; Off white solid; FT IR (ATR, $\left.v_{\max }, \mathrm{cm}^{-1}\right)$ : $3409(\mathrm{O}-\mathrm{H}), 3056$ (ArH), 2937 and $2858(\mathrm{C}-\mathrm{H}), 1724(\mathrm{C}=\mathrm{O}$ of acid), $1641(\mathrm{C}=\mathrm{O}$ of amide), $1620(\mathrm{C}=\mathrm{N}), 1573(\mathrm{C}=\mathrm{C})$, 1299 (C-O), 1251 (C-F); ${ }^{1} \mathrm{H}$ NMR (400 MHz, DMSO-d $d_{6}, \delta$ ppm): 10.80 (s, 1H, indole-NH), 8.67 (d, 1H, amide N-H, $J=7.6 \mathrm{~Hz}$ ), 8.27 (s, 1H, Ar-H), 7.95 (d, 1H, Ar-H, J=8.4 Hz), 7.71-7.80 (m, 2H, Ar-H), 7.60-7.63 (m, 2H, Ar-H), 7.49-7.53 (m, 1H, Ar-H), 7.32 (d, 1H, Ar-H, J = 8.0 Hz), 7.23 (s, 1H, Ar-H), 7.04-7.08 (m, 1H, Ar-H), 6.98-7.01 (m, 1H, Ar-H), 4.67-4.72 (m, 1H, chiral C-H), 3.83-3.89 (m, 1H, N-CH), 3.22-3.28 (m, 2H, indolyl $\left.\mathrm{CH}_{2}\right), 2.07-2.18$ (m, 2H, cyclohexyl), 1.79-1.90 (m, 4H, cyclohexyl), 1.59-1.61 (m, 1H, cyclohexyl), 1.17-1.28 (m, 3H, cyclohexyl); ${ }^{13} \mathrm{C}$ NMR (100 MHz, DMSO- $d_{6}, \delta$ ppm): 173.6, 166.6, 161.9, 159.5, 145.8, 142.8, 136.2, 135.1, 134.8, 133.6, 128.1, 127.2, 125.9, 123.6, 122.5, 120.9, 119.4, 119.2, 118.4, 118.1, 114.9, 114.7, 112.3, 111.5, 110.5, 57.2, 53.9, 30.8, 26.6, 25.3, 24.3; ESI-MS $(m / z): 559.3[\mathrm{M}+\mathrm{H}]^{+}, 561.3[\mathrm{M}+2+\mathrm{H}]^{+}$; Anal. calcd. for $\mathrm{C}_{31} \mathrm{H}_{28} \mathrm{~N}_{4} \mathrm{ClFO}_{3}$ : C, 66.60; H, 5.05; N, 10.02. Found: C, 66.57; H, 5.08; N, 10.01.

\section{General procedure for the synthesis of 3-aryl-1H-pyrazole-4-carboxaldehydes (10a-c)}

3-Aryl-1H-pyrazole-4-carboxaldehydes (10a-c) were prepared according to the general procedure described in the literature ${ }^{11}$ by means of Vilsmeier-Haack reaction on 2-(1- 
1 arylethylidene)hydrazinecarboxamides (9a-c) which in-turn were prepared by the reaction of

2 substituted acetophenones (8a-c) with semicarbazide hydrochloride in acetic acid-sodium acetate

3 buffer. In a typical experiment, to an ice-cold solution of (1-arylethylidene)

4 hydrazinecarboxamides $(9 a-c)(10 \mathrm{mmol})$ in $\mathrm{DMF}(20 \mathrm{~mL}), \mathrm{POCl}_{3}(50 \mathrm{mmol})$ was added dropwise

5 with stirring at $0{ }^{\circ} \mathrm{C}$. After complete addition, the reaction mass was stirred at room temperature

6 for about $30 \mathrm{~min}$ and then at $60-65^{\circ} \mathrm{C}$ for $8 \mathrm{~h}$. The reaction mixture was allowed to cool to room

7 temperature and then quenched with crushed ice, followed by neutralization with $25 \%$ sodium

8 hydroxide solution. The solid obtained was filtered, washed with water and dried. The crude

9 product was used as such for the next step.

General procedure for the synthesis of 2-(4-oxo-2-thioxothiazolidin-3-yl)amino acids (12a-d)

2-(4-Oxo-2-thioxothiazolidin-3-yl)amino acids (12a-d) were prepared according to the reported

12 procedure. ${ }^{21}$ Appropriate amino acid (11a-d, $10 \mathrm{mmol}$ ) was dissolved in a solution of potassium hydroxide $(10 \mathrm{mmol})$ in water $(10 \mathrm{~mL})$. Carbon disulfide $(10 \mathrm{mmol})$ was added dropwise to the

14 above clear solution and stirred at room temperature for 6-12 h. An aqueous solution of potassium 15 chloroacetate $(10 \mathrm{mmol})$ was then added and continued stirring for further $30 \mathrm{~min}$. The reaction mixture was acidified with $2 \mathrm{~N} \mathrm{HCl}$ to $\mathrm{pH} 3.0$ and stirred at $90{ }^{\circ} \mathrm{C}$ for $1-3 \mathrm{~h}$. The reaction mixture

17 was poured onto crushed ice and solid obtained was filtered, washed with water, dried and used as such for the next step. Whenever a gummy solid was obtained, it was extracted to ethyl acetate, 19 concentrated in vacuo and triturated with hexane to get orange solid.

21 General procedure for the synthesis of pyrazole conjugated rhodanine carboxylic acids (13a22 l) 
$\beta$-Alanine (0.02 mol, 2.0 equiv.) was added to a clear solution of pyrazole aldehyde (10a-c, 0.01 mol, 1.0 equiv.) and rhodanine amino acid (12a-d, 0.01 mol, 1.0 equiv.) in acetic acid (10 mL).

Then the reaction mixture was heated to reflux for 16-18 $\mathrm{h}$. After completion of the reaction (monitored by TLC hexane: ethyl acetate $(2: 1, \mathrm{v} / \mathrm{v}))$, the reaction mass was allowed to cool to room temperature and poured onto crushed ice to get yellow to orange colored solid. The solid separated was filtered, washed with water, dried and subjected to column purification (10 to $50 \%$ ethyl acetate in hexane) to obtain pure product.

\section{(S)-2-(5-((3-(4-Methoxyphenyl)-1H-pyrazol-4-yl)methylene)-4-oxo-2-thioxothiazolidin-3-}

yl)acetic acid (13a): Yield 60\%; Mp 164-166 ${ }^{\circ} \mathrm{C}$; Red solid; FT IR (ATR, $v_{\max }, \mathrm{cm}^{-1}$ ): 3400 (OH), $3001(\mathrm{Ar}-\mathrm{H}), 2933$ and $2858(\mathrm{C}-\mathrm{H}), 1705(\mathrm{C}=\mathrm{O}), 1610(\mathrm{C}=\mathrm{N}), 1529(\mathrm{C}=\mathrm{C}), 1228(\mathrm{C}=\mathrm{S}), 1106$ $(\mathrm{C}-\mathrm{O}) ;{ }^{1} \mathrm{H}$ NMR (400 MHz, DMSO- $\left.d_{6}, \delta \mathrm{ppm}\right): 8.05$ (s, 1H, pyrazole-5H), $7.53(\mathrm{~s}, 1 \mathrm{H},=\mathrm{C}-\mathrm{H})$, $7.49(\mathrm{~d}, 2 \mathrm{H}, \mathrm{Ar}-\mathrm{H}, J=8.4 \mathrm{~Hz}), 7.12(\mathrm{~d}, 2 \mathrm{H}, \mathrm{Ar}-\mathrm{H}, J=8.8 \mathrm{~Hz}), 3.57\left(\mathrm{~s}, 2 \mathrm{H}, \mathrm{CH}_{2}\right) ;{ }^{13} \mathrm{C} \mathrm{NMR}(100$ MHz, DMSO- $d_{6}, \delta$ ppm): 192.1, 169.6, 166.0, 160.1, 130.1, 125.4, 117.4, 114.6, 112.8, 55.3, 43.1; ESI-MS (m/z): 374.2 [M-H] ; Anal. calcd. for $\mathrm{C}_{16} \mathrm{H}_{13} \mathrm{~N}_{3} \mathrm{O}_{4} \mathrm{~S}_{2}:$ C, 51.19; H, 3.49; N, 11.19. Found: C, 51.21; H, 3.46; N, 11.14.

(S)-2-(5-((3-(4-Methoxyphenyl)-1H-pyrazol-4-yl)methylene)-4-oxo-2-thioxothiazolidin-3yl)propanoic acid (13b): Yield 65\%; Mp 150-152 ${ }^{\circ} \mathrm{C}$; Red solid; FT IR (ATR, $v_{\max }, \mathrm{cm}^{-1}$ ): 3496 $(\mathrm{O}-\mathrm{H}), 3172(\mathrm{Ar}-\mathrm{H}), 2903$ and $2856(\mathrm{C}-\mathrm{H}), 1709(\mathrm{C}=\mathrm{O}), 1608(\mathrm{C}=\mathrm{N}), 1516(\mathrm{C}=\mathrm{C}), 1247(\mathrm{C}=\mathrm{S})$, $1111(\mathrm{C}-\mathrm{O}) ;{ }^{1} \mathrm{H}$ NMR (400 MHz, DMSO- $d_{6}, \delta$ ppm): 8.05 (s, 1H, pyrazole-5H), 7.53 (s, 1H, =CH), 7.49 (d, 2H, Ar-H, J=8.4 Hz), 7.12 (d, 2H, Ar-H, $J=8.8 \mathrm{~Hz}), 5.55-5.61$ (q, 1H, J = 7.2 Hz), $3.82\left(\mathrm{~s}, 3 \mathrm{H}, \mathrm{OCH}_{3}\right), 1.51\left(\mathrm{~d}, 3 \mathrm{H}, \mathrm{CH}_{3}, J=6.8 \mathrm{~Hz}\right) ;{ }^{13} \mathrm{C}$ NMR (100 MHz, DMSO-d $\left.6, \delta \mathrm{ppm}\right): 192.1$, 169.6, 166.0, 160.1, 130.1, 125.4, 117.4, 114.6, 112.8, 55.3, 52.8, 13.4; ESI-MS (m/z): 388.2 [M$\mathrm{H}]^{-}$; Anal. calcd. for $\mathrm{C}_{17} \mathrm{H}_{15} \mathrm{~N}_{3} \mathrm{O}_{4} \mathrm{~S}_{2}$ : C, 52.43; H, 3.88; N, 10.79. Found: C, 52.41; H, 3.85; N, 10.81 .

(S)-2-(5-((3-(4-Methoxyphenyl)-1H-pyrazol-4-yl)methylene)-4-oxo-2-thioxothiazolidin-3-yl)-3phenylpropanoic acid (13c): Yield 48\%; Mp 122-124 ${ }^{\circ} \mathrm{C}$; Red solid; FT IR (ATR, $v_{\max }, \mathrm{cm}^{-1}$ ): 3279 (O-H), 3001 (Ar-H), 2933 and $2858(\mathrm{C}-\mathrm{H}), 1702(\mathrm{C}=\mathrm{O}), 1610(\mathrm{C}=\mathrm{N}), 1529(\mathrm{C}=\mathrm{C}), 1250$ 
$(\mathrm{C}=\mathrm{S}), 1172(\mathrm{C}-\mathrm{O}) ;{ }^{1} \mathrm{H}$ NMR (400 MHz, DMSO- $\left.d_{6}, \delta \mathrm{ppm}\right): 7.86$ (s, 1H, pyrazole-5H), 7.32-7.35 (m, 3H, Ar-H), 6.92-7.12 (m, 7H, Ar-H, =C-H, Ph), 5.67 (overlapped multiplet, 1H, chiral CH), $3.68\left(\mathrm{~s}, 3 \mathrm{H}, \mathrm{OCH}_{3}\right), 3.13-3.16\left(\mathrm{~m}, 2 \mathrm{H}, \mathrm{CH}_{2}\right) ;{ }^{13} \mathrm{C}$ NMR (100 MHz, DMSO-d $\left.6, \delta \mathrm{ppm}\right): 192.1$, 169.6, 166.0, 160.1, 136.5, 130.1, 128.9, 128.2, 126.7, 125.4, 117.4, 114.6, 112.8, 58.1, 55.3, 33.1; ESI-MS (m/z): 464.2 [M-H] ; Anal. calcd. for $\mathrm{C}_{23} \mathrm{H}_{19} \mathrm{~N}_{3} \mathrm{O}_{4} \mathrm{~S}_{2}$ : C, 59.34; H, 4.11; N, 9.03. Found: C, 59.31; H, 4.10; N, 9.05.

\section{(S)-3-(1H-Indol-3-yl)-2-(5-((3-(4-methoxyphenyl)-1H-pyrazol-4-yl)methylene)-4-oxo-2-}

thioxothiazolidin-3-yl)propanoic acid (13d): Yield 85\%; Mp 160-162 ${ }^{\circ} \mathrm{C}$; Red solid; FT IR (ATR, $\left.v_{\max }, \mathrm{cm}^{-1}\right): 3274(\mathrm{O}-\mathrm{H}), 3001(\mathrm{Ar}-\mathrm{H}), 2929$ and $2853(\mathrm{C}-\mathrm{H}), 1705(\mathrm{C}=\mathrm{O}), 1608(\mathrm{C}=\mathrm{N}), 1513$ $(\mathrm{C}=\mathrm{C}), 1253(\mathrm{C}=\mathrm{S}), 1177$ (C-O); ${ }^{1} \mathrm{H}$ NMR (400 MHz, DMSO-d $6, \delta$ ppm): 10.77 (s, 1H, indole NH), 7.98 (s, 1H, pyrazole-5H), 7.45-7.49 (m, 4H, Ar-H, =C-H), 7.27-7.29 (m, 1H, Ar-H), 7.12$7.15(\mathrm{~d}, 2 \mathrm{H}, \mathrm{Ar}-\mathrm{H}, J=8.4 \mathrm{~Hz}), 6.99-7.05(\mathrm{~m}, 2 \mathrm{H}, \mathrm{Ar}-\mathrm{H}), 6.89-6.93(\mathrm{~m}, 1 \mathrm{H}, \mathrm{Ar}-\mathrm{H}), 5.86$ (overlapped multiplet, $1 \mathrm{H}$, chiral $\mathrm{CH}$ ), $3.83\left(\mathrm{~s}, 3 \mathrm{H}, \mathrm{OCH}_{3}\right), 3.56-3.61$ (dd, $2 \mathrm{H}, \mathrm{CH}_{2}, J=14.8 \mathrm{~Hz}$ and $5.2 \mathrm{~Hz}) ;{ }^{13} \mathrm{C}$ NMR (100 MHz, DMSO-d $6, \delta$ ppm): 192.1, 169.1, 166.3, 160.1, 135.9, 130.1, 127.1, 125.2, 123.7, 120.9, 118.4, 117.8, 114.6, 112.7, 111.3, 108.9, 58.0, 55.3, 23.0; ESI-MS $(m / z): 503.2[\mathrm{M}-\mathrm{H}]^{-} ;$Anal. calcd. for $\mathrm{C}_{25} \mathrm{H}_{20} \mathrm{~N}_{4} \mathrm{O}_{4} \mathrm{~S}_{2}$ : C, 59.51; H, 4.00; N, 11.10. Found: C, 59.49; H, 4.10; N, 11.06 .

(S)-2-(5-((3-(4-Nitrophenyl)-1H-pyrazol-4-yl)methylene)-4-oxo-2-thioxothiazolidin-3-yl)acetic acid (13e): Yield 72\%; Mp 136-138 ${ }^{\circ} \mathrm{C}$; Yellow solid; FT IR (ATR, v $\left.v_{\max }, \mathrm{cm}^{-1}\right): 3332(\mathrm{O}-\mathrm{H}), 3116$ $(\mathrm{Ar}-\mathrm{H}), 2967$ and $2856(\mathrm{C}-\mathrm{H}), 1703(\mathrm{C}=\mathrm{O}), 1601(\mathrm{C}=\mathrm{N}), 1548(\mathrm{C}=\mathrm{C}), 1332(\mathrm{~N}=\mathrm{O}), 1241(\mathrm{C}=\mathrm{S})$, 1127 (C-O); ${ }^{1} \mathrm{H}$ NMR (400 MHz, DMSO-d $6, \delta$ ppm): 8.40 (d, 2H, Ar-H, J = $8.0 \mathrm{~Hz}$ ), 8.30 (s, 1H, pyrazole-5H), $7.87(\mathrm{~d}, 2 \mathrm{H}, \mathrm{Ar}-\mathrm{H}, J=8.4 \mathrm{~Hz}), 7.56(\mathrm{~s}, 1 \mathrm{H},=\mathrm{C}-\mathrm{H}), 3.56\left(\mathrm{~s}, 2 \mathrm{H}, \mathrm{CH}_{2}\right) ;{ }^{13} \mathrm{C}$ NMR (100 MHz, DMSO- $d_{6}, \delta$ ppm): 192.1, 169.6, 165.9, 147.4, 129.8, 124.3, 124.1, 119.3, 113.6, 43.1; ESI-MS (m/z): 479.2 [M-H]; Anal. calcd. for $\mathrm{C}_{15} \mathrm{H}_{10} \mathrm{~N}_{4} \mathrm{O}_{5} \mathrm{~S}_{2}: \mathrm{C}, 46.15 ; \mathrm{H}, 2.58 ; \mathrm{N}, 14.35$. Found: C, 46.12; H, 2.55; N, 14.29.

(S)-2-(5-((3-(4-Nitrophenyl)-1H-pyrazol-4-yl)methylene)-4-oxo-2-thioxothiazolidin-3yl)propanoic acid (13f): Yield 68\%; Mp 240-242 ${ }^{\circ} \mathrm{C}$; Yellow solid; FT IR (ATR, $v_{\max }, \mathrm{cm}^{-1}$ ): 3223 (O-H), $3116(\mathrm{Ar}-\mathrm{H}), 2967$ and $2862(\mathrm{C}-\mathrm{H}), 1702(\mathrm{C}=\mathrm{O}), 1601(\mathrm{C}=\mathrm{N}), 1548(\mathrm{C}=\mathrm{C}), 1336(\mathrm{~N}=\mathrm{O})$, $1247(\mathrm{C}=\mathrm{S}), 1127$ (C-O); ${ }^{1} \mathrm{H}$ NMR (400 MHz, DMSO-d,$\delta$ ppm): 8.39 (d, 2H, Ar-H, J = 8.4 Hz), 
8.30 (s, 1H, pyrazole-5H), 7.87 (d, 2H, Ar-H, J=8.8 Hz), 7.58 (s, 1H, =C-H), 5.56-5.62 (q, 1H, chiral $\mathrm{CH}, J=7.2 \mathrm{~Hz}), 1.52\left(\mathrm{~d}, 3 \mathrm{H}, \mathrm{CH}_{3}, J=6.8 \mathrm{~Hz}\right) ;{ }^{13} \mathrm{C}$ NMR (100 MHz, DMSO- $d_{6}, \delta$ ppm): 192.1, 169.5 , 165.9, 147.4, 129.7, 124.3, 124.1, 119.3, 113.6, 52.8, 13.3; ESI-MS (m/z): 403.2 [M$\mathrm{H}]^{-}$; Anal. calcd. for $\mathrm{C}_{16} \mathrm{H}_{12} \mathrm{~N}_{4} \mathrm{O}_{5} \mathrm{~S}_{2}$ : C, 47.52; H, 2.99; N, 13.85. Found: C, 47.55; H, 2.96; N, 13.82 .

(S)-2-(5-((3-(4-Nitrophenyl)-1H-pyrazol-4-yl)methylene)-4-oxo-2-thioxothiazolidin-3-yl)-3phenylpropanoic acid (13g): Yield 67\%; Mp 90-92 ${ }^{\circ} \mathrm{C}$; Yellow solid; FT IR (ATR, $v_{\max }, \mathrm{cm}^{-1}$ ): $3256(\mathrm{O}-\mathrm{H}), 3025(\mathrm{Ar}-\mathrm{H}), 2921$ and $2851(\mathrm{C}-\mathrm{H}), 1713(\mathrm{C}=\mathrm{O}), 1601(\mathrm{C}=\mathrm{N}), 1337(\mathrm{~N}=\mathrm{O}), 1230$ $(\mathrm{C}=\mathrm{S}), 1107$ (C-O); ${ }^{1} \mathrm{H}$ NMR (400 MHz, DMSO-d $6, \delta$ ppm): 8.40 (d, 2H, Ar-H, J = 8.0 Hz), 8.30 (s, 1H, pyrazole-5H), 7.87 (d, 2H, Ar-H, J=8.4 Hz), 7.56 (s, 1H, =C-H), 7.13-7.2 (m, 5H, Ar-H), 5.86 (overlapped multiplet, $1 \mathrm{H}$, chiral $\mathrm{CH}$ ), 2.09 (s, 2H, CH2); ${ }^{13} \mathrm{C}$ NMR (100 MHz, DMSO-d $6, \delta$ ppm): 192.1, 168.7, 166.1, 147.4, 136.5, 129.7, 128.9, 128.2, 126.7, 124.4, 124.1, 118.6, 113.5, 58.1, 33.1; ESI-MS (m/z): 479.2 [M-H]'; Anal. calcd. for $\mathrm{C}_{22} \mathrm{H}_{16} \mathrm{~N}_{4} \mathrm{O}_{5} \mathrm{~S}_{2}$ : C, 54.99; H, 3.36; N, 11.66. Found: C, 54.96; H, 3.38; N, 11.63.

(S)-3-(1H-indol-3-yl)-2-(5-((3-(4-nitrophenyl)-1H-pyrazol-4-yl)methylene)-4-oxo-2thioxothiazolidin-3-yl)propanoic acid (13h): Yield 83\%; Mp 152-154 ${ }^{\circ} \mathrm{C}$; Yellow solid; FT IR (ATR, $\left.v_{\max }, \mathrm{cm}^{-1}\right): 3271(\mathrm{O}-\mathrm{H}), 3023(\mathrm{Ar}-\mathrm{H}), 2928$ and $2852(\mathrm{C}-\mathrm{H}), 1713(\mathrm{C}=\mathrm{O}), 1603(\mathrm{C}=\mathrm{N})$, $1334(\mathrm{~N}=\mathrm{O}), 1231(\mathrm{C}=\mathrm{S}), 1108(\mathrm{C}-\mathrm{O}) ;{ }^{1} \mathrm{H}$ NMR (400 MHz, DMSO-d,$\delta$ ppm): 10.84 (s, 1H, indole-NH), 8.47 (d, 2H, Ar-H, $J=8.3 \mathrm{~Hz}), 8.38(\mathrm{~s}, 1 \mathrm{H}$, pyrazole-5H), $7.92(\mathrm{~d}, 2 \mathrm{H}, \mathrm{Ar}-\mathrm{H}, J=8.5$ Hz), 7.59 (s, 1H, =C-H), 7.53 (d, 1H, Ar-H, J= 7.6 Hz), 7.33 (d, 1H, Ar-H, J = 8.0 Hz), 7.11 (s, 1H, Ar-H), 7.05-7.09 (m, 1H, Ar-H), 6.95-6.99 (m, 1H, Ar-H), 5.91 (overlapped multiplet, 1H, chiral $\mathrm{CH}$ ), 3.62-3.67 (dd, $2 \mathrm{H}, \mathrm{CH}_{2}, J=15.2 \mathrm{~Hz}$ and $\left.5.2 \mathrm{~Hz}\right) ;{ }^{13} \mathrm{C}$ NMR (100 MHz, DMSO-d,$\delta$ ppm): 192.1, 169.4, 166.1, 147.6, 135.9, 129.7, 127.1, 124.3, 124.1, 123.7, 120.9, 119.3, 118.4, 117.8, 113.6, 111.3, 108.9, 55.3, 23.0; ESI-MS $(\mathrm{m} / \mathrm{z})$ : $518.2[\mathrm{M}-\mathrm{H}]^{-}$; Anal. calcd. for $\mathrm{C}_{24} \mathrm{H}_{17} \mathrm{~N}_{5} \mathrm{O}_{5} \mathrm{~S}_{2}$ : C, 55.48; H, 3.30; N, 13.48. Found: C, 55.44; H, 3.28; N, 13.45.

(S)-2-(5-((3-(3,5-Difluorophenyl)-1H-pyrazol-4-yl)methylene)-4-oxo-2-thioxothiazolidin-3yl)acetic acid (13i): Yield 83\%; Mp 108-110 ${ }^{\circ} \mathrm{C}$; Yellow solid; FT IR (ATR, vmax, $\mathrm{cm}^{-1}$ ): 3325 (OH), $3001(\mathrm{Ar}-\mathrm{H}), 2929$ and $2848(\mathrm{C}-\mathrm{H}), 1703(\mathrm{C}=\mathrm{O}), 1605(\mathrm{C}=\mathrm{N}), 1512(\mathrm{C}=\mathrm{C}), 1253(\mathrm{C}=\mathrm{S}), 1122$ (C-F), 1060 (C-O); ${ }^{1} \mathrm{H}$ NMR (400 MHz, DMSO- $d_{6}, \delta$ ppm): 8.16 (s, 1H, pyrazole-5H), 7.51 (s, 
$1 \mathrm{H},=\mathrm{C}-\mathrm{H}), 7.29-7.38(\mathrm{~m}, 3 \mathrm{H}, \mathrm{Ar}-\mathrm{H}), 3.57$ (s, 2H, $\left.\mathrm{CH}_{2}\right) ;{ }^{13} \mathrm{C}$ NMR (100 MHz, DMSO- $d_{6}, \delta$ ppm): 192.1, 169.2, 166.2, 163.8, 163.7, 161.4, 161.2, 124.4, 119.0, 113.3, 111.9, 111.8, 111.7. 111.6, 104.4, 43.1; ESI-MS (m/z): 374.2 [M-H] ${ }^{-}$; Anal. calcd. for $\mathrm{C}_{15} \mathrm{H}_{9} \mathrm{~N}_{3} \mathrm{~F}_{2} \mathrm{O}_{3} \mathrm{~S}_{2}$ : C, 47.24; $\mathrm{H}, 2.38 ; \mathrm{N}$, 11.02. Found: C, 47.27; H, 2.35; N, 11.04 .

\section{(S)-2-(5-((3-(3,5-Difluorophenyl)-1H-pyrazol-4-yl)methylene)-4-oxo-2-thioxothiazolidin-3-}

yl)propanoic acid (13j): Yield 57\%; Mp 110-112 ${ }^{\circ} \mathrm{C}$; Yellow solid; FT IR (ATR, $v_{\max }, \mathrm{cm}^{-1}$ ): 3246 (O-H), $3087(\mathrm{Ar}-\mathrm{H}), 2922$ and $2858(\mathrm{C}-\mathrm{H}), 1712(\mathrm{C}=\mathrm{O}), 1604(\mathrm{C}=\mathrm{N}), 1534(\mathrm{C}=\mathrm{C}), 1243(\mathrm{C}=\mathrm{S})$, 1120 (C-F), 1056 (C-O); ${ }^{1} \mathrm{H}$ NMR (400 MHz, DMSO- $d_{6}, \delta$ ppm): 8.21 (s, 1H, pyrazole-5H), 7.55 $(\mathrm{s}, 1 \mathrm{H},=\mathrm{C}-\mathrm{H}), 7.29-7.38(\mathrm{~m}, 3 \mathrm{H}, \mathrm{Ar}-\mathrm{H}), 5.55-5.61(\mathrm{q}, 1 \mathrm{H}$, chiral $\mathrm{CH}, J=7.2 \mathrm{~Hz}), 1.52(\mathrm{~d}, 3 \mathrm{H}$, $\left.\mathrm{CH}_{3}, J=7.2 \mathrm{~Hz}\right) ;{ }^{13} \mathrm{C}$ NMR (100 MHz, DMSO- $\left.d_{6}, \delta \mathrm{ppm}\right): 192.1,169.5,165.9,163.8,163.7$, 161.4, 161.2, 124.4, 118.9, 113.3, 111.9, 111.8, 111.7, 111.6, 104.3, 52.8, 13.3; ESI-MS (m/z): 394.2 [M-H] $]^{-}$; Anal. calcd. for $\mathrm{C}_{16} \mathrm{H}_{11} \mathrm{~N}_{3} \mathrm{~F}_{2} \mathrm{O}_{3} \mathrm{~S}_{2}$ : C, 48.60; H, 2.80; N, 10.63. Found: C, 48.57; H, 2.81; N, 10.66.

(S)-2-(5-((3-(3,5-Difluorophenyl)-1H-pyrazol-4-yl)methylene)-4-oxo-2-thioxothiazolidin-3-yl)3-phenylpropanoic acid (13k): Yield 61\%; Mp 114-116 ${ }^{\circ} \mathrm{C}$; Yellow solid; FT IR (ATR, $v_{\max }, \mathrm{cm}^{-}$ $\left.{ }^{1}\right)$ : $3253(\mathrm{O}-\mathrm{H}), 3025(\mathrm{Ar}-\mathrm{H}), 2924$ and $2858(\mathrm{C}-\mathrm{H}), 1716(\mathrm{C}=\mathrm{O}), 1604(\mathrm{C}=\mathrm{N}), 1535(\mathrm{C}=\mathrm{C}), 1230$ $(\mathrm{C}=\mathrm{S}), 1122(\mathrm{C}-\mathrm{F}) ;{ }^{1} \mathrm{H}$ NMR (400 MHz, DMSO- $d_{6}, \delta$ ppm): 8.29 (s, 1H, pyrazole-5H), 7.54 (s, $1 \mathrm{H},=\mathrm{C}-\mathrm{H}), 7.32-7.41(\mathrm{~m}, 3 \mathrm{H}, \mathrm{Ar}-\mathrm{H}), 7.14-7.22$ (m, 5H, Ar-H), 5.85 (overlapped multiplet, 1H, chiral CH), 3.29-3.33 (m, 2H, $\left.\mathrm{CH}_{2}\right) ;{ }^{13} \mathrm{C}$ NMR (100 MHz, DMSO- $d_{6}, \delta$ ppm): 192.2, 168.7, 166.2, $163.8,163.7,161.4,161.2,136.5,128.9,128.2$, 126.6, 124.6, 118.3, 113.2, 111.9, 111.7, 104.3, 58.2, 33.1; ESI-MS (m/z): 470.2 [M-H] ; Anal. calcd. for $\mathrm{C}_{22} \mathrm{H}_{15} \mathrm{~N}_{3} \mathrm{~F}_{2} \mathrm{O}_{3} \mathrm{~S}_{2}$ : C, 56.04; H, 3.21; N, 8.91. Found: C, 56.01; H, 3.24; N, 8.89.

(S)-2-(5-((3-(3,5-Difluorophenyl)-1H-pyrazol-4-yl)methylene)-4-oxo-2-thioxothiazolidin-3-yl)3-(1H-indol-3-yl)propanoic acid (13l): Yield 83\%; Mp 120-122 ${ }^{\circ} \mathrm{C}$; Yellow solid; FT IR (ATR, $\left.v_{\max }, \mathrm{cm}^{-1}\right): 3411(\mathrm{O}-\mathrm{H}), 3081(\mathrm{Ar}-\mathrm{H}), 2924$ and $2858(\mathrm{C}-\mathrm{H}), 1709(\mathrm{C}=\mathrm{O}), 1604(\mathrm{C}=\mathrm{N}), 1534$ $(\mathrm{C}=\mathrm{C}), 1223(\mathrm{C}=\mathrm{S}), 1121(\mathrm{C}-\mathrm{F}) ;{ }^{1} \mathrm{H}$ NMR (400 MHz, DMSO-d6, $\left.\delta \mathrm{ppm}\right): 10.77$ (s, 1H, indole$\mathrm{NH}), 8.16(\mathrm{~s}, 1 \mathrm{H}$, pyrazole-5H), $7.51(\mathrm{~s}, 1 \mathrm{H},=\mathrm{C}-\mathrm{H}), 7.45-7.47(\mathrm{~m}, 1 \mathrm{H}, \mathrm{Ar}-\mathrm{H}), 7.36-7.45(\mathrm{~m}, 1 \mathrm{H}$, Ar-H), 7.26-7.30 (m, 3H, Ar-H), 6.99-7.05 (m, 2H, Ar-H), 6.89-6.92 (m, 1H, Ar-H), 5.86 (s, 1H, chiral C-H), 3.56-3.61 (dd, $2 \mathrm{H}, \mathrm{CH}_{2}, J=14.8 \mathrm{~Hz}$ and $\left.4.8 \mathrm{~Hz}\right) ;{ }^{13} \mathrm{C}$ NMR (100 MHz, DMSO- $d_{6}, \delta$ 
ppm): 192.1, 169.0, 166.2, 163.8, 163.7, 161.4, 161.2, 135.9, 127.0, 124.2, 123.7, 120.9, 118.6, 118.4, 117.8, 113.2, 111.9, 111.8, 111.7, 111.6, 111.3, 108.9, 104.4, 58.1, 23.0; ESI-MS (m/z): $509.2[\mathrm{M}-\mathrm{H}]^{-}$; Anal. calcd. for $\mathrm{C}_{24} \mathrm{H}_{16} \mathrm{~N}_{4} \mathrm{~F}_{2} \mathrm{O}_{3} \mathrm{~S}_{2}$ : C, 56.46; H, 3.16; N, 10.97. Found: C, 56.42; H, $3.18 ; \mathrm{N}, 10.94$.

\section{Biological evaluation:}

Evaluation of Sirt1/2/3 inhibition activity. Test and standard compounds at a concentration of $10 \mu \mathrm{M}$ were incubated with 5 IU of Recombinant Human SIRT1/2/3 protein and SIRT1 substrate (Flour-delys-SIRT1)/Sirt2 substrate (Flour-delys-SIRT2)/Sirt3 substrate (Flour-delys-SIRT2) at a concentration of $25 \mu \mathrm{M}$ in presence of $200 \mu \mathrm{M}$ of NAD+ for 10 to $15 \mathrm{~min}$. After taking the initial fluorescence value at 360/460 $\mathrm{nm}$ excitation/emission wavelength, the sample mixture was incubated at $37^{\circ} \mathrm{C}$ for 30 minutes. After completion of the incubation period, developing solution was added to the reaction mixture and florescence was observed at 360/460 nm excitation/emission wavelength. Percentage inhibition of Sirt 1/2/3 was calculated.

Determination of IC50 value of Sirt1 activity. Different concentrations (ranges from $50 \mathrm{~nm}$ to $1000 \mathrm{~nm}$ ) of test and standard compounds were incubated with 5 IU of Recombinant Human Sirt1 protein and with substrate (Flour-delys-Sirt1) at a concentration of $25 \mu \mathrm{M}$ in the presence of 200 $\mu \mathrm{M}$ of NAD+ as recommended by the manufacturer kit (Enzo life sciences cat. No. BML-AK55). Initial fluorescence was taken at 360/460 nm Excitation/Emission wavelength before incubating the sample at $37{ }^{\circ} \mathrm{C}$ for 30 minutes. Developing solution was added to the reaction mixture and the florescence was observed at 360/460 nm excitation/emission wavelength. Percentage inhibition of Sirt1 was calculated, the concentration-response curve was plotted and IC50 was determined.

Evaluation of SIRT1/2 and 3 inhibition activity in HepG2 cells. HepG2 cells were obtained from ATCC and maintained in DMEM media with $10 \% \mathrm{FBS}$ and $1 \mu \mathrm{g} / \mathrm{mL}$ pen strip antibiotic at $37{ }^{\circ} \mathrm{C}$ and $5 \% \mathrm{CO}_{2}$ and $95 \% \mathrm{O}_{2}$. To evaluate the Sirt 1 and $2 / 3$ activity, cells were treated with test and standard compounds at a concentration of $10 \mu \mathrm{M}$ for $6 \mathrm{~h}$. After $6 \mathrm{~h}$, the cells were washed with PBS, lysed with lysis buffer and measured the Sirt1 and 2/3 activity using the cell lysate as discussed before.

Western blotting. HepG2, a human liver cancer cells (ATCC) were grown under standard conditions. Cells were treated with the test compounds at a concentration of $25 \mu \mathrm{M}$ for $48 \mathrm{~h}$. Cells were lysed and protein samples were prepared with RIPA buffer. Western blots were carried out 
to determine the levels of acetylated p53 and Sirt 1 in treated cells. Primary antibody for acetylatedp53 (Abcam cat.no ab61241) and Sirt1 (Cell signaling cat.no.\#9475), and secondary antibody were used at dilutions recommended by the manufacturer.

Cell Viability Assays. Cell lines (HepG2, Caco2, and MCF7) were obtained from ATCC and were grown under standard conditions. To perform cell viability assays, cells were seeded into 96-well plates and treated with test compounds in DMSO (final DMSO concentration 0.25\%). Cells were incubated with test compounds at different concentrations $(1,10,100,200,300$, and $400 \mu \mathrm{M}$, or DMSO control) for $24 \mathrm{~h}$, then cells were incubated with $10 \mu \mathrm{L}$ of $2 \mathrm{mg} / \mathrm{mL}$ MTT ( Merck millipore, cat no. 475989) solution in PBS for about 2 to $3 \mathrm{~h}$, then MTT solution was aspirated from the plate and $50 \mu \mathrm{L}$ of DMSO was added to each well and plates were kept on rocking shaker for 30 min, absorbance was taken at $570 \mathrm{~nm}$, \% viability was determined. Assays were carried out in triplicate. Reported values are averages of two independent experiments.

\section{In-Silico Computational Methods:}

All calculations were performed, on a Linux Centos7.0 based Workstation (RAM 132GB, CPUcore 8, GPU-card 1 GTX1080) and Linux Centos 6.9 based Server (RAM 64GB, CPU(S) 64, GPU(S) 2 Tesla-P100), by using the Maestro release 2017-2 graphical user interface (GUI) of the Schrodinger software suite ${ }^{54}$, VMD 1.9.3 ${ }^{55}$, ChemDraw Professional 15.1. ${ }^{56}$ and Desmond-3.7 ${ }^{57}$. Ligand Preparation. All Ligands were drawn by ChemDraw Professional 15.1, and then, LigPrep (LigPrep, Maestro 11.2.014, Schrödinger LLC) with OPLS3 ${ }^{58}$ force field, was used to build ligands, generate stereoisomers and tautomers. Further, ligands were desalted and protonated at pH 7.0 \pm 2.0 through the tool Epik (Shelley et al., 2007) module. For other parameters, the default values were assigned. Qikprop, Lipinsnki's rule of five and reactive functional group screening were performed to check the drug likiness of ligands. ${ }^{59}$

Cheminformatic Analysis: Molecular weight and cLogP for all compounds were calculated by by ChemDraw.

Selection of structures and molecular modeling. Presently, two X-ray crystal structures available for Sirt1-inhibitor complex in the Protein Data Bank (PDB), and their PDB id's are 4I5I and 4ZZI. Both structures were imported and prepared in maestro, further enrichment calculation was performed to select the best structure for the docking studies. A total of 1000 decoys molecule and, three actives (reported inhibitor) Ex527, Ex527-anlogue (PDB id 4I5I) and 4TO (PDB id 
4ZZI) were used to calculate enrichment and receiver operating characteristics (ROC) plot.

2 Finally, molecular modeling was performed to get the final protein-ligand complex for further study. ${ }^{60}$

4 Protein Preparation and Grid Generation. Structures were prepared through the Protein

5 Preparation Wizard Workflow, Maestro module of Schrödinger software. Protein Preparation Wizard Workflow performed the basic preparation tasks, like proper assignment of bonds, addition of hydrogen, creation of zero-order bong to metals, disulfide bonds creation, and deletion of water molecules beyond $5 \AA$ from the het group, in step by step way. After protein preparation, water sampling and basic restrain minimization that allows only hydrogen atoms to be freely minimized was performed by using force field OPLS3. ${ }^{61}$ Subsequently, with the help of Glide (Glide, Maestro 11.2.014, Schrödinger LLC), receptor grids of these complexes were generated. A virtual grid box of volume $20 \times 20 \times 20 \AA$ region in space centred at the original ligand of the complex structures was consider generating receptor grid. For the other parameters, the default values were assigned. ${ }^{62}$ Selection of Docking Model and Docking. Docking was performed with Glide in extra precision (XP) mode at pre-defined grid with flexible ligand sampling and epic state penalties and other parameters were set to default.

Pose correction Binding Pose Metadynamics. To find the correct binding pose of ligands at the binding pocket, we have run a series of metadynamics MD simulations for " $2 \mathrm{~ns}$ " on each set of docked protein-ligand complex. Binding pose metadynamics, was performed through Desmond metadynamics MD simulation, it evaluates the comparative stability of binding pose. Total 10 no. of trial per pose was selected to perform the study.

MMGBSA Binding Energy calculation. Binding free energy of protein-ligand docked complex $\left(\Delta \mathrm{G}_{\text {bind }}\right)$ was calculated by MM-GBSA protocol through Prime (Prime, Maestro 11.2.014, Schrödinger LLC). MM-GBSA calculation was performed for each protein ligand complex and control, by using force field, OPLS3 and salvation model, variable-dielectric generalized Born (VSGB) model ${ }^{63}$. We used this $\Delta \mathbf{G}_{\text {bind }}$ to rank protein-ligand docked complex and ligand showing the highest negative value selected as best ligands for further biological study.

The per-residue energy decomposition of MD system was calculated through MM(GB/PB)SA protocol implemented in Amber. ${ }^{64}$ Total 200 snapshots extracted from equilibrated trajectory of 
each system and binding energy was calculated through MMGBSA.py script implemented in amber.

$\Delta \mathrm{G}_{\text {bind, }}$ is the total sum of difference in minimized energy ( $\Delta \mathrm{E}_{\mathrm{MM}}$ ), difference in solvation energy $\left(\Delta \mathrm{G}_{\mathrm{solv}}\right)$, and difference in surface area energy.

$\Delta \mathbf{G}_{\text {bind }}=\Delta \mathbf{E}_{M M}+\Delta \mathbf{G}_{\text {solv }}+\Delta \mathbf{G S A}$

$\Delta \mathrm{E}_{M M}=\operatorname{Emin}_{(\text {complex })}-\left(\operatorname{Emin}_{(\text {protein })}+\operatorname{Emin}_{(\text {ligand })}\right)$

$\Delta \mathbf{G}_{\text {solv }}=\mathbf{G}_{\text {solv }}$ (complex) $-\left(\mathbf{G}_{\text {solv }}\right.$ (protein) $\left.+\mathbf{G}_{\text {solv (ligand) }}\right)$

$\Delta \mathbf{G}_{\mathrm{SA}}=\mathbf{G S A}_{\mathrm{SA}}$ (complex) $-\left(\mathrm{GSA}_{\mathrm{SA}}\right.$ (protein) $+\mathbf{G}_{\mathrm{SA} \text { (ligand) })}$

Molecular Dynamics Simulation. Molecular dynamics (MD) simulation study for apo and holo of all complexes were carried out using Desmond. ${ }^{65}$ System Builder panel with inbuilt OPLS3 force field was used to build molecular systems. Further solvation was done with TIP3P water molecules using orthorhombic box with distance of $10 \AA$ from all sides of protein complex. Orthorhombic box volume was minimized by reorientation of the complex/model system. Appropriate no. of counter $\mathrm{Na}^{+} / \mathrm{Cl}^{-}$ions were added to electrically neutralize the system. The Steepest descent algorithm with 2000 iterations and convergence threshold of $1 \mathrm{kcal} / \mathrm{mol} / \AA ̊ \AA$ was used to minimize all prepared systems, then further equilibration was performed by using default algorithm which includes two stages of minimization and 4 stages of MD. Finally, $100 \mathrm{~ns}$ of molecular dynamics simulation was performed using NPT ensemble with temperature and pressure coupling of $300 \mathrm{~K}$ and $1 \mathrm{~atm}$ respectively. Coordinates and energy were recorded every 10 ps to yield 10000 frames. ${ }^{66}$

\section{ASSOCIATED CONTENT}

* Supplementary information file.

The Supporting Information is available free of charge on the ACS Publications website.

\section{AUTHOR INFORMATION}

Corresponding Authors

*SKB.: e-mail, skbanerjee@ thsti.res.in; phone, +91 01292876475

*BP.: e-mail, bojapoojary@gmail.com; phone, +91 9686940403

*SA.: e-mail, sasthana@ thsti.res.in; phone, +91 01292876489, 8447568689 


\section{AUTHOR CONTRIBUTIONS}

2 Shailendra Asthana designed this work. Nikil Purushotham and Boja Poojary performed chemical

3 synthesis, Mrityunjay Singh and Shailendra Asthana performed and designed molecular docking

4 and molecular dynamics simulations studies, Bugga Paramesha and Sanjay K Banerjee performed

5 and supervised experimental assays. All authors wrote this paper and have approved the final

6 version of the manuscript.

$7 \quad \$$ Nikil Purushotham, Mrityunjay Singh and Bugga Paramesha contribute equally to this work.

9 ACKNOWLEDGMENTS

10 Nikil Purushotham is thankful to DST New Delhi for the INSPIRE fellowship. Mrityunjay Singh 11 and Bugga Paramesha are thankful to Council of Scientific \& Industrial Research (CSIR), New 12 Delhi for awarding Senior Research Fellowship and Junior Research Fellowship, respectively. 13 Boja Poojary is thankful to UGC SAP for financial assistance. Sanjay K Banerjee and Shailendra 14 Asthana are thankful to THSTI for providing the necessary support and core funding.

\section{CONFLICTS OF INTERESTS}

17 The authors declare that they do not have any conflicts of interest.

18 COMPETING FINANCIAL INTERESTS

The author(s) declare no competing financial interest.

\section{Abbreviations:}

22 Sirt1-3: Sirt1, Sirt2 and Sirt3

23 Sirt1: NAD-dependent protein deacetylase sirtuin-1, Silent information regulator2 homolog 1

24 Sirt2: NAD-dependent protein deacetylase sirtuin-2, Silent information regulator2 homolog 2

25 Sirt3: NAD-dependent protein deacetylase sirtuin-3, Silent information regulator2 homolog 3

26 MD simulation: Molecular Dynamics Simulation

27 HepG2 cells: Human hepatoma G2, Human liver cancer cell

28 MCF cells: Michigan Cancer Foundation-7, breast cancer cells

29 IC $\mathrm{I}_{50}$ : half maximal inhibitory concentration

30 HBs: Hydrogen bonds

31 ESP: Electrostatic surface potential 
$1 \mu \mathrm{M}$ : micro molar

2 ns: Nano-seconds

3 h: Hour

4 MM-GBSA: Molecular Mechanic-Generalized Born Surface Area

5 RMSD: Root mean Square deviation

6 RMSF: Root mean square fluctuation

7 Ex527*: Ex527 analogue with 7-memberd ring

8 


\section{REFERENCES}

1. Hsu, W. W.; Wu, B.; Liu, W. R. Sirtuins 1 and 2 Are Universal Histone Deacetylases. ACS Chemical Biology 2016, 11, 792-799.

2. Michan, S.; Sinclair, D. Sirtuins in mammals: insights into their biological function. Biochemical Journal 2007, 404, 1-13.

3. Liu, T.; Liu, P. Y.; Marshall, G. M. The critical role of the class III histone deacetylase SIRT1 in cancer. Cancer research 2009, 69, 1702-1705.

4. Jeong, S. M.; Haigis, M. C. Sirtuins in cancer: a balancing act between genome stability and metabolism. Molecules and cells 2015, 38, 750.

5. Frye, R. A. Phylogenetic classification of prokaryotic and eukaryotic Sir2-like proteins. Biochemical and biophysical research communications 2000, 273, 793-798.

6. Yuan, H.; Marmorstein, R. Structural basis for sirtuin activity and inhibition. Journal of Biological Chemistry 2012, jbc. R112. 372300.

7. Haigis, M. C.; Sinclair, D. A. Mammalian sirtuins: biological insights and disease relevance. Annual Review of Pathological Mechanical Disease 2010, 5, 253-295.

8. Sebastián, C.; Satterstrom, F. K.; Haigis, M. C.; Mostoslavsky, R. From sirtuin biology to human diseases: an update. Journal of Biological Chemistry 2012, 287, 42444-42452.

9. Niederer, F.; Ospelt, C.; Brentano, F.; Hottiger, M. O.; Gay, R. E.; Gay, S.; Detmar, M.; Kyburz, D. SIRT1 overexpression in the rheumatoid arthritis synovium contributes to proinflammatory cytokine production and apoptosis resistance. Annals of the rheumatic diseases 2011, annrheumdis 148957.

10. Engler, A.; Tange, C.; Frank-Bertoncelj, M.; Gay, R. E.; Gay, S.; Ospelt, C. Regulation and function of SIRT1 in rheumatoid arthritis synovial fibroblasts. Journal of Molecular Medicine 2016, 94, 173-182.

11. Pinzone, M. R.; Cacopardo, B.; Condorelli, F.; Rosa, M. D.; Nunnari, G. Sirtuin-1 and HIV-1: an overview. Current drug targets 2013, 14, 648-652.

12. Morselli, E.; Maiuri, M.; Markaki, M.; Megalou, E.; Pasparaki, A.; Palikaras, K.; Criollo, A.; Galluzzi, L.; Malik, S.; Vitale, I. Caloric restriction and resveratrol promote longevity through the Sirtuin1-dependent induction of autophagy. Cell death \& disease 2011, 1, e10.

13. Zhao, X.; Allison, D.; Condon, B.; Zhang, F.; Gheyi, T.; Zhang, A.; Ashok, S.; Russell, M.; MacEwan, I.; Qian, Y. The $2.5 \AA$ crystal structure of the SIRT1 catalytic domain bound to nicotinamide adenine dinucleotide (NAD+) and an indole (EX527 analogue) reveals a novel mechanism of histone deacetylase inhibition. Journal of medicinal chemistry 2013, 56, 963-969.

14. Vaziri, H.; Dessain, S. K.; Eaton, E. N.; Imai, S.-I.; Frye, R. A.; Pandita, T. K.; Guarente, L.; Weinberg, R. A. hSIR2SIRT1 functions as an NAD-dependent p53 deacetylase. cell 2001, 107, 149-159.

15. Motta, M. C.; Divecha, N.; Lemieux, M.; Kamel, C.; Chen, D.; Gu, W.; Bultsma, Y.; McBurney, M.; Guarente, L. Mammalian SIRT1 represses forkhead transcription factors. Cell 2004, 116, 551-563. 16. Yeung, F.; Hoberg, J. E.; Ramsey, C. S.; Keller, M. D.; Jones, D. R.; Frye, R. A.; Mayo, M. W. Modulation of NF - KB - dependent transcription and cell survival by the SIRT1 deacetylase. The EMBO journal 2004, 23, 2369-2380.

17. Mayoral, R.; Osborn, O.; McNelis, J.; Johnson, A. M.; Izquierdo, C. L.; Chung, H.; Li, P.; Traves, P. G.; Bandyopadhyay, G.; Pessentheiner, A. R. Adipocyte SIRT1 knockout promotes PPARY activity, adipogenesis and insulin sensitivity in chronic-HFD and obesity. Molecular metabolism 2015, 4, 378-391. 18. Gurd, B. J. Deacetylation of PGC-1 $\alpha$ by SIRT1: importance for skeletal muscle function and exercise-induced mitochondrial biogenesis. Applied Physiology, Nutrition, and Metabolism 2011, 36, 589-597. 
19. Jeong, J.; Juhn, K.; Lee, H.; Kim, S.-H.; Min, B.-H.; Lee, K.-M.; Cho, M.-H.; Park, G.-H.; Lee, K.-H. SIRT1 promotes DNA repair activity and deacetylation of Ku70. Experimental \& molecular medicine 2007, $39,8$.

20. Nogueiras, R.; Habegger, K. M.; Chaudhary, N.; Finan, B.; Banks, A. S.; Dietrich, M. O.; Horvath, T. L.; Sinclair, D. A.; Pfluger, P. T.; Tschöp, M. H. Sirtuin 1 and sirtuin 3: physiological modulators of metabolism. Physiological reviews 2012, 92, 1479-1514.

21. Chang, H.-C.; Guarente, L. SIRT1 and other sirtuins in metabolism. Trends in Endocrinology \& Metabolism 2014, 25, 138-145.

22. Chen, H.-C.; Jeng, Y.-M.; Yuan, R.-H.; Hsu, H.-C.; Chen, Y.-L. SIRT1 promotes tumorigenesis and resistance to chemotherapy in hepatocellular carcinoma and its expression predicts poor prognosis. Annals of surgical oncology 2012, 19, 2011-2019.

23. Wang, Z.; Chen, W. Emerging roles of SIRT1 in cancer drug resistance. Genes \& cancer 2013, 4, $82-90$.

24. Kojima, K.; Ohhashi, R.; Fujita, Y.; Hamada, N.; Akao, Y.; Nozawa, Y.; Deguchi, T.; Ito, M. A role for SIRT1 in cell growth and chemoresistance in prostate cancer PC3 and DU145 cells. Biochemical and biophysical research communications 2008, 373, 423-428.

25. Xia, X.; Zhou, X. Knockdown of SIRT1 inhibits proliferation and promotes apoptosis of paclitaxelresistant human cervical cancer cells. Cellular and molecular biology (Noisy-le-Grand, France) 2018, 64, 36-41.

26. Asaka, R.; Miyamoto, T.; Yamada, Y.; Ando, H.; Mvunta, D. H.; Kobara, H.; Shiozawa, T. Sirtuin 1 promotes the growth and cisplatin resistance of endometrial carcinoma cells: a novel therapeutic target. Laboratory Investigation 2015, 95, 1363-1373.

27. Choi, H.-K.; Cho, K. B.; Phuong, N. T. T.; Han, C. Y.; Han, H.-K.; Hien, T. T.; Choi, H. S.; Kang, K. W. SIRT1-Mediated FoxO1 Deacetylation Is Essential for Multidrug Resistance-Associated Protein 2 Expression in Tamoxifen-Resistant Breast Cancer Cells. Molecular Pharmaceutics 2013, 10, 2517-2527. 28. Ota, H.; Tokunaga, E.; Chang, K.; Hikasa, M.; lijima, K.; Eto, M.; Kozaki, K.; Akishita, M.; Ouchi, Y.; Kaneki, M. Sirt1 inhibitor, Sirtinol, induces senescence-like growth arrest with attenuated Ras-MAPK signaling in human cancer cells. Oncogene 2006, 25, 176.

29. Sundriyal, S.; Moniot, S. b.; Mahmud, Z.; Yao, S.; Di Fruscia, P.; Reynolds, C. R.; Dexter, D. T.; Sternberg, M. J.; Lam, E. W.-F.; Steegborn, C. Thienopyrimidinone based sirtuin-2 (SIRT2)-selective inhibitors bind in the ligand induced selectivity pocket. Journal of medicinal chemistry 2017, 60, 19281945.

30. Cen, Y. Sirtuins inhibitors: the approach to affinity and selectivity. Biochimica et Biophysica Acta (BBA)-Proteins and Proteomics 2010, 1804, 1635-1644.

31. Dai, H.; Case, A. W.; Riera, T. V.; Considine, T.; Lee, J. E.; Hamuro, Y.; Zhao, H.; Jiang, Y.; Sweitzer, S. M.; Pietrak, B. Crystallographic structure of a small molecule SIRT1 activator-enzyme complex. Nature communications 2015, 6, 1-10.

32. Park, J. B. Finding potent sirt inhibitor in coffee: Isolation, confirmation and synthesis of javamide-II (N-caffeoyltryptophan) as sirt1/2 inhibitor. PloS one 2016, 11.

33. Yoon, Y.; Osman, H.; Choon, T. Potent sirtuin inhibition with 1, 2, 5-trisubstituted benzimidazoles. MedChemComm 2016, 7, 2094-2099.

34. Rumpf, T.; Schiedel, M.; Karaman, B.; Roessler, C.; North, B. J.; Lehotzky, A.; Oláh, J.; Ladwein, K. I.; Schmidtkunz, K.; Gajer, M. Selective Sirt2 inhibition by ligand-induced rearrangement of the active site. Nature communications 2015, 6, 6263.

45 35. Di Fruscia, P.; Zacharioudakis, E.; Liu, C.; Moniot, S.; Laohasinnarong, S.; Khongkow, M.; Harrison, 46 I. F.; Koltsida, K.; Reynolds, C. R.; Schmidtkunz, K. The Discovery of a Highly Selective 5, 6, 7, 8 - 
Tetrahydrobenzo $[4,5]$ thieno $[2,3-\mathrm{d}]$ pyrimidin - $4(3 \mathrm{H})$ - one SIRT2 Inhibitor that is Neuroprotective in an in vitro Parkinson's Disease Model. ChemMedChem 2015, 10, 69-82.

36. Hoffmann, G.; Breitenbücher, F.; Schuler, M.; Ehrenhofer-Murray, A. E. A novel sirtuin 2 (SIRT2) inhibitor with p53-dependent pro-apoptotic activity in non-small cell lung cancer. Journal of Biological Chemistry 2014, 289, 5208-5216.

37. Outeiro, T. F.; Kontopoulos, E.; Altmann, S. M.; Kufareva, I.; Strathearn, K. E.; Amore, A. M.; Volk, C. B.; Maxwell, M. M.; Rochet, J.-C.; McLean, P. J. Sirtuin 2 inhibitors rescue $\alpha$-synuclein-mediated toxicity in models of Parkinson's disease. science 2007, 317, 516-519.

38. Napper, A. D.; Hixon, J.; McDonagh, T.; Keavey, K.; Pons, J.-F.; Barker, J.; Yau, W. T.; Amouzegh, P.; Flegg, A.; Hamelin, E. Discovery of indoles as potent and selective inhibitors of the deacetylase SIRT1. Journal of medicinal chemistry 2005, 48, 8045-8054.

39. Therrien, E.; Larouche, G.; Nguyen, N.; Rahil, J.; Lemieux, A.-M.; Li, Z.; Fournel, M.; Yan, T. P.; Landry, A.-J.; Lefebvre, S. Discovery of bicyclic pyrazoles as class III histone deacetylase SIRT1 and SIRT2 inhibitors. Bioorganic \& medicinal chemistry letters 2015, 25, 2514-2518.

40. Disch, J. S.; Evindar, G.; Chiu, C. H.; Blum, C. A.; Dai, H.; Jin, L.; Schuman, E.; Lind, K. E.; Belyanskaya, S. L.; Deng, J. Discovery of thieno [3, 2-d] pyrimidine-6-carboxamides as potent inhibitors of SIRT1, SIRT2, and SIRT3. Journal of medicinal chemistry 2013, 56, 3666-3679.

41. Ghosh, A.; Sengupta, A.; Seerapu, G. P. K.; Nakhi, A.; Ramarao, E. V. S.; Bung, N.; Bulusu, G.; Pal, M.; Haldar, D. A novel SIRT1 inhibitor, 4bb induces apoptosis in HCT116 human colon carcinoma cells partially by activating $\mathrm{p} 53$. Biochemical and biophysical research communications 2017, 488, 562-569. 42. Tae, I. H.; Park, E. Y.; Dey, P.; Son, J. Y.; Lee, S.-Y.; Jung, J. H.; Saloni, S.; Kim, M.-H.; Kim, H. S. Novel SIRT1 inhibitor 15-deoxy- $\Delta 12,14$-prostaglandin $J 2$ and its derivatives exhibit anticancer activity through apoptotic or autophagic cell death pathways in SKOV3 cells. International journal of oncology 2018, 53, 2518-2530.

43. Wang, M.; Rakesh, K.; Leng, J.; Fang, W.-Y.; Ravindar, L.; Gowda, D. C.; Qin, H.-L. Amino acids/peptides conjugated heterocycles: A tool for the recent development of novel therapeutic agents. Bioorganic chemistry 2018, 76, 113-129.

44. Peck, B.; Chen, C.-Y.; Ho, K.-K.; Di Fruscia, P.; Myatt, S. S.; Coombes, R. C.; Fuchter, M. J.; Hsiao, C.-D.; Lam, E. W.-F. SIRT inhibitors induce cell death and p53 acetylation through targeting both SIRT1 and SIRT2. Molecular cancer therapeutics 2010, 1535-7163. MCT-09-0971.

45. Solomon, J. M.; Pasupuleti, R.; Xu, L.; McDonagh, T.; Curtis, R.; DiStefano, P. S.; Huber, L. J. Inhibition of SIRT1 catalytic activity increases p53 acetylation but does not alter cell survival following DNA damage. Molecular and cellular biology 2006, 26, 28-38.

46. Mahajan, S. S.; Scian, M.; Sripathy, S.; Posakony, J.; Lao, U.; Loe, T. K.; Leko, V.; Thalhofer, A.; Schuler, A. D.; Bedalov, A. Development of pyrazolone and isoxazol-5-one cambinol analogues as sirtuin inhibitors. Journal of medicinal chemistry 2014, 57, 3283-3294.

47. Reed, S. M.; Quelle, D. E. p53 acetylation: regulation and consequences. Cancers 2015, 7, 30-69. 48. Yi, J.; Luo, J. SIRT1 and p53, effect on cancer, senescence and beyond. Biochimica et Biophysica Acta (BBA)-Proteins and Proteomics 2010, 1804, 1684-1689.

49. Mellini, P.; Itoh, Y.; Elboray, E. E.; Tsumoto, H.; Li, Y.; Suzuki, M.; Takahashi, Y.; Tojo, T.; Kurohara, T.; Miyake, Y. Identification of Diketopiperazine-Containing 2-Anilinobenzamides as Potent Sirtuin 2 (SIRT2)-Selective Inhibitors Targeting the "Selectivity Pocket", Substrate-Binding Site, and NAD+-Binding Site. Journal of medicinal chemistry 2019, 62, 5844-5862.

50. Chen, L. Medicinal chemistry of sirtuin inhibitors. Current medicinal chemistry 2011, 18, 19361946.

51. Du, J.; Zhou, Y.; Su, X.; Yu, J. J.; Khan, S.; Jiang, H.; Kim, J.; Woo, J.; Kim, J. H.; Choi, B. H. Sirt5 is a NAD-dependent protein lysine demalonylase and desuccinylase. Science 2011, 334, 806-809. 
52. Jiang, H.; Khan, S.; Wang, Y.; Charron, G.; He, B.; Sebastian, C.; Du, J.; Kim, R.; Ge, E.;

Mostoslavsky, R. SIRT6 regulates TNF- $\alpha$ secretion through hydrolysis of long-chain fatty acyl lysine. Nature 2013, 496, 110-113.

53. Roessler, C.; Nowak, T.; Pannek, M.; Gertz, M.; Nguyen, G. T.; Scharfe, M.; Born, I.; Sippl, W.; Steegborn, C.; Schutkowski, M. Chemical probing of the human sirtuin 5 active site reveals its substrate acyl specificity and peptide - based inhibitors. Angewandte Chemie International Edition 2014, 53, 10728-10732.

54. Schrödinger, L. Schrödinger Release 2017-2: Maestro. Schrödinger LLC, New York 2017. 55. Humphrey, W.; Dalke, A.; Schulten, K. VMD: visual molecular dynamics. Journal of molecular graphics 1996, 14, 33-38.

56. Mills, N. ChemDraw Ultra 10.0 CambridgeSoft, 100 CambridgePark Drive, Cambridge, MA 02140. www. cambridgesoft. com. Commercial Price: 1910fordownload, 2150 for CD-ROM; Academic Price: 710fordownload, 800 for CD-ROM. In ACS Publications: 2006.

57. Release, S. 1: Desmond molecular dynamics system, version 3.7. DE Shaw Research, New York, NY, Maestro-Desmond Interoperability Tools, version 2014, 3.

58. Harder, E.; Damm, W.; Maple, J.; Wu, C.; Reboul, M.; Xiang, J. Y.; Wang, L.; Lupyan, D.; Dahlgren, M. K.; Knight, J. L. OPLS3: a force field providing broad coverage of drug-like small molecules and proteins. Journal of chemical theory and computation 2016, 12, 281-296.

59. Repasky, M. P.; Shelley, M.; Friesner, R. A. Flexible ligand docking with Glide. Current protocols in bioinformatics 2007, 18, 8.12.1-8.12. 36.

60. Asthana, S.; Zucca, P.; Vargiu, A. V.; Sanjust, E.; Ruggerone, P.; Rescigno, A. Structure-Activity Relationship Study of Hydroxycoumarins and Mushroom Tyrosinase. Journal of agricultural and food chemistry 2015, 63, 7236-44.

61. Mattapally, S.; Singh, M.; Murthy, K. S.; Asthana, S.; Banerjee, S. K. Computational modeling suggests impaired interactions between NKX2.5 and GATA4 in individuals carrying a novel pathogenic D16N NKX2.5 mutation. Oncotarget 2018, 9, 13713-13732.

62. Mittal, L.; Kumari, A.; Suri, C.; Bhattacharya, S.; Asthana, S. Insights into structural dynamics of allosteric binding sites in HCV RNA-dependent RNA polymerase. Journal of biomolecular structure \& dynamics 2020, 38, 1612-1625.

63. Li, J.; Abel, R.; Zhu, K.; Cao, Y.; Zhao, S.; Friesner, R. A. The VSGB 2.0 model: a next generation energy model for high resolution protein structure modeling. Proteins: Structure, Function, and Bioinformatics 2011, 79, 2794-2812.

64. Mittal, L.; Srivastava, M.; Asthana, S. Conformational Characterization of Linker Revealed the Mechanism of Cavity Formation by 227 G in BVDV RDRP. The Journal of Physical Chemistry B 2019, 123, 6150-6160.

65. Srivastava, M.; Suri, C.; Singh, M.; Mathur, R.; Asthana, S. Molecular dynamics simulation reveals the possible druggable hot-spots of USP7. Oncotarget 2018, 9, 34289.

66. Subramanian, L.; Maghajothi, S.; Singh, M.; Kesh, K.; Kalyani, A.; Sharma, S.; Khullar, M.; Victor, S. M.; Swarnakar, S.; Asthana, S.; Mullasari, A. S.; Mahapatra, N. R. A Common Tag Nucleotide Variant in MMP7 Promoter Increases Risk for Hypertension via Enhanced Interactions With CREB (Cyclic AMP Response Element-Binding Protein) Transcription Factor. Hypertension (Dallas, Tex. : 1979) 2019, 74, 1448-1459. 
1

2

3 Abstract graphics

4

5

6

7

8

9

10

11

12

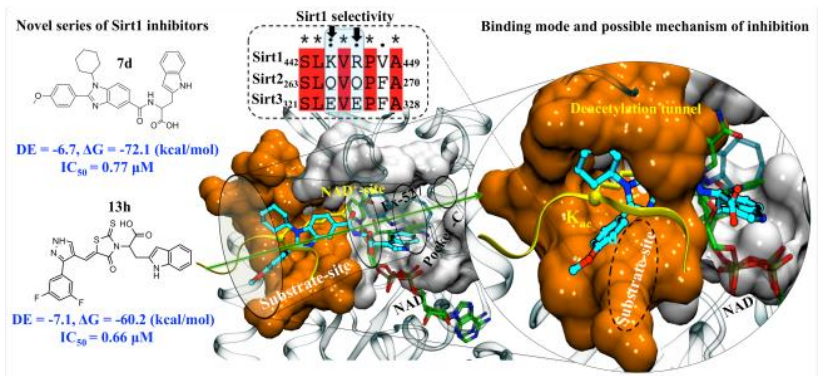




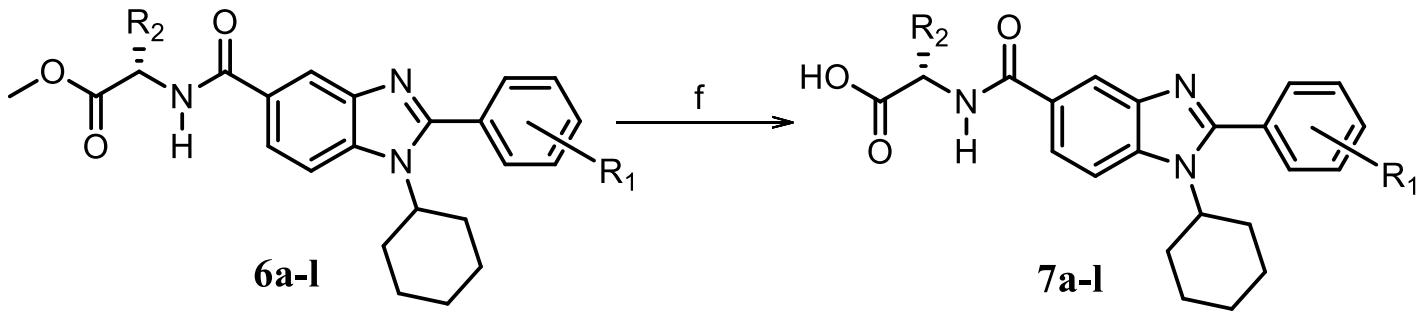

7 a Reagents and conditions: (a) EtOH, conc. $\mathrm{H}_{2} \mathrm{SO}_{4}$ (catalytic), reflux; (b) Cyclohexylamine (2.5

8 equiv.), TEA (3.0 equiv.), THF, r.t.; (c) Substituted benzaldehyde (1 equiv.), $\mathrm{Na}_{2} \mathrm{~S}_{2} \mathrm{O}_{4}$ (3 equiv.), 9 DMSO, $90{ }^{\circ} \mathrm{C}$; (d) $\mathrm{NaOH}$ (1.1 eqiv.), water, reflux; (e) Amino acid methyl ester hydrochloride (1 equiv.), NMM (2.5 equiv.), TBTU (1.25 equiv.), DMF, r.t.; (f) $\mathrm{LiOH}_{\text {. }}{ }_{2} \mathrm{O}$ (1 equiv.), water:THF $11(2: 1), 0^{\circ} \mathrm{C}$.

$12 \mathrm{R}_{1}{ }^{*}=4-\mathrm{F}, 4-\mathrm{OCH}_{3}, 2-\mathrm{Cl}-6-\mathrm{F} ; \mathrm{R}_{2}{ }^{*}=\mathrm{CH}_{3}, \mathrm{CH}\left(\mathrm{CH}_{3}\right)_{2}, \mathrm{CH}_{2}-\mathrm{CH}\left(\mathrm{CH}_{3}\right)_{2}$, 3-indolylmethyl.

13 *Further for substitution pattern see Table 1 
1 Scheme 2: Synthetic strategy for the preparation of pyrazole conjugated rhodanine carboxylic $2 \quad \operatorname{acids}^{\mathrm{a}}$. (13a-l)

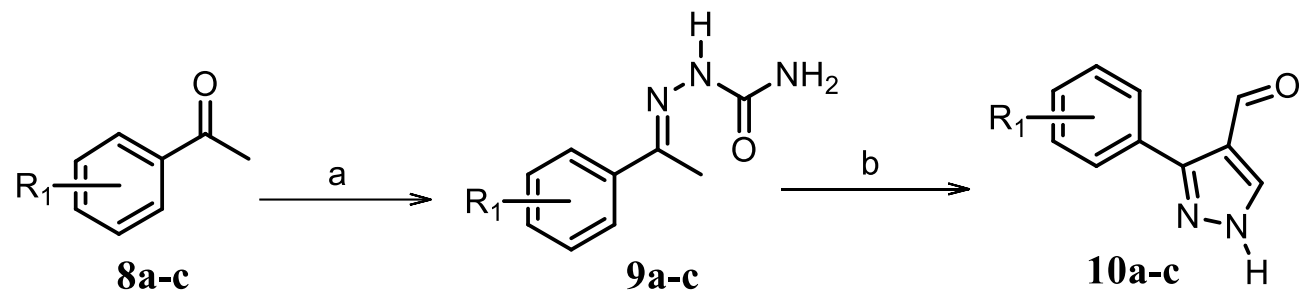<smiles>[R2]C(N)C(=O)O</smiles>

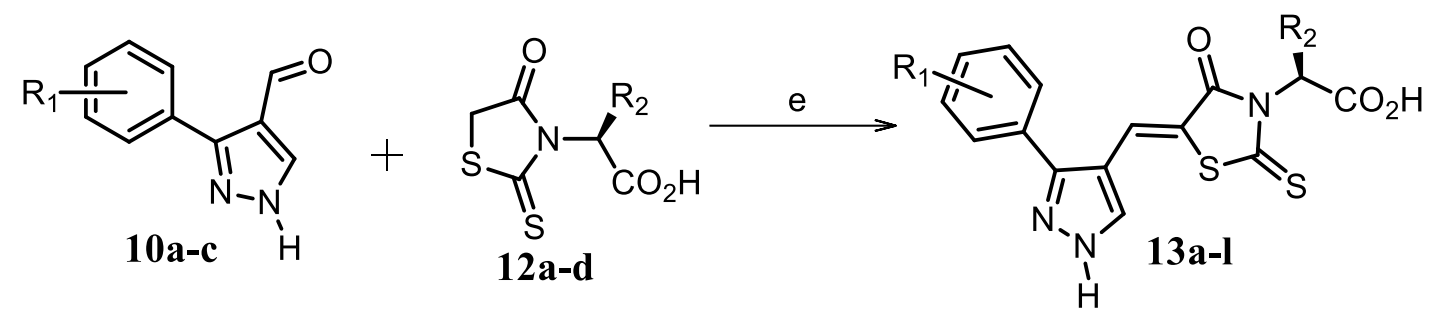

4 aReagents and conditions: (a) Semicarbazide hydrochloride (1.1 equiv.), NaOAc (1.3 equiv.),

5 EtOH, reflux; (b) $\mathrm{POCl}_{3}$ (10 equiv.), reflux; (c) $\mathrm{CS}_{2}$ (1.2 equiv.), $\mathrm{KOH}$ (1 equiv.), water, rt; (d)

6 Potassium chloroacetate (1 equiv.), $2 \mathrm{~N} \mathrm{HCl}$ till $\mathrm{pH} 2,90^{\circ} \mathrm{C}$; (e) $\beta$-alanine (2 equiv.), AcOH, reflux.

$7 \quad \mathrm{R}_{1}{ }^{*}=4-\mathrm{OCH}_{3}, 4-\mathrm{NO}_{2}, 3,5-\mathrm{F}_{2} ; \mathrm{R}_{2}{ }^{*}=\mathrm{H}, \mathrm{CH}_{3}, \mathrm{CH}_{2}-\mathrm{C}_{6} \mathrm{H}_{5}, 3$-indolylmethyl.

8 *Further for substitution pattern see Table 2. 
2 Figures:

3 Figure 1: Representative reported structure of sirtuin inhibitors with their $\mathrm{IC}_{50}$ values. The 4 carboxamide functionality and benzimidazole/pyrazole/indole scaffolds are highlighted in bold 5 blue color, while region for selectivity are marked with dotted circle.<smiles>CS(=O)(=O)NCCC1CCN(C2=NC=NC3C=C(C(N)=O)SC23)CC1</smiles>

(1) Sirt1: $4 \mathrm{nM}$ Sirt2: $1 \mathrm{nM}$<smiles></smiles>

SirReal2 (4) Sirt1: $>50 \mu \mathrm{M}$ Sirt2: $0.4 \mu \mathrm{M}$<smiles>N#C/C(=C/c1ccc(-c2cc(Cl)ccc2Cl)o1)C(=O)Nc1cccc2ncccc12</smiles>

AGK2 (7)

Sirt1: $>50 \mu \mathrm{M}$ Sirt2: $3.5 \mu \mathrm{M}$<smiles>O=C(/C=C/c1ccc(O)c(O)c1)NC(Cc1c[nH]c2ccccc12)C(=O)O</smiles>

(2) Javamide-II Sirt1: $\mathbf{3 4} \mu \mathrm{M}$ Sirt2: $8.7 \mu \mathrm{M}$<smiles>COc1ccc2ccccc2c1Cn1cnc2sc3c(c2c1=O)CCC(NCc1cccnc1)C3</smiles>

(5) Sirt1: $>100 \mu \mathrm{M}$ Sirt2: $1.45 \mu \mathrm{M}$

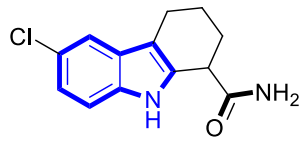

Ex527 (8) Sirt1: $0.098 \mu \mathrm{M}$ Sirt2: $19.6 \mu \mathrm{M}$ Sirt3: $48.7 \mu \mathrm{M}$
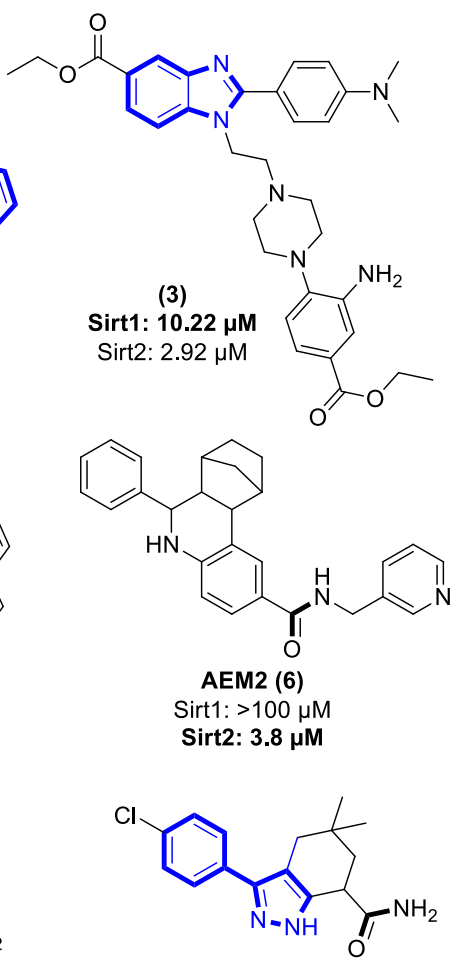

(9)

SIRT1: $0.8 \mu \mathrm{M}$

SIRT2: $1.7 \mu \mathrm{M}$<smiles>CCNC(=O)c1ccc(C(=O)NCCC2CCN(c3ncnc4cc(C(N)=O)sc34)CC2)s1</smiles>

Sirt1: $0.004 \mu \mathrm{M}$

Sirt2: $0.003 \mu \mathrm{M}$ 
Figure 2. Architecture of Sirt1 catalytic site: A) Structure of Human Sirt1 with Inhibitor Ex527-

2 analogue (Ex527*) and co-factor NAD, "PDB id: 4I5I". In right-inset enlarged surface view of

3 catalytic grove (cut-off distance $6.0 \AA$ ), with Ex527*, NAD+ and docked Ex527. NAD+ is shown

4 in licorice representation rendered in atom wise i.e carbon atom in cyan color, while Ex527* and

5 Ex527 are shown in ball and sticks representation in which carbon atoms are in cyan and green

6 color, respectively. B) Heat map of MM-GBSA and docking score of all designed compounds

7 docked on Sirt1, Sirt2 and Sirt3. The cut-off scores is highlighted with dotted black box. All ligand

8 are represented in the form of small square, colour of square represent respective colour of MM-

9 GBSA heat-map. Ligand 7d, 13d, 13h and 131 are marked with arrows in left most panel.

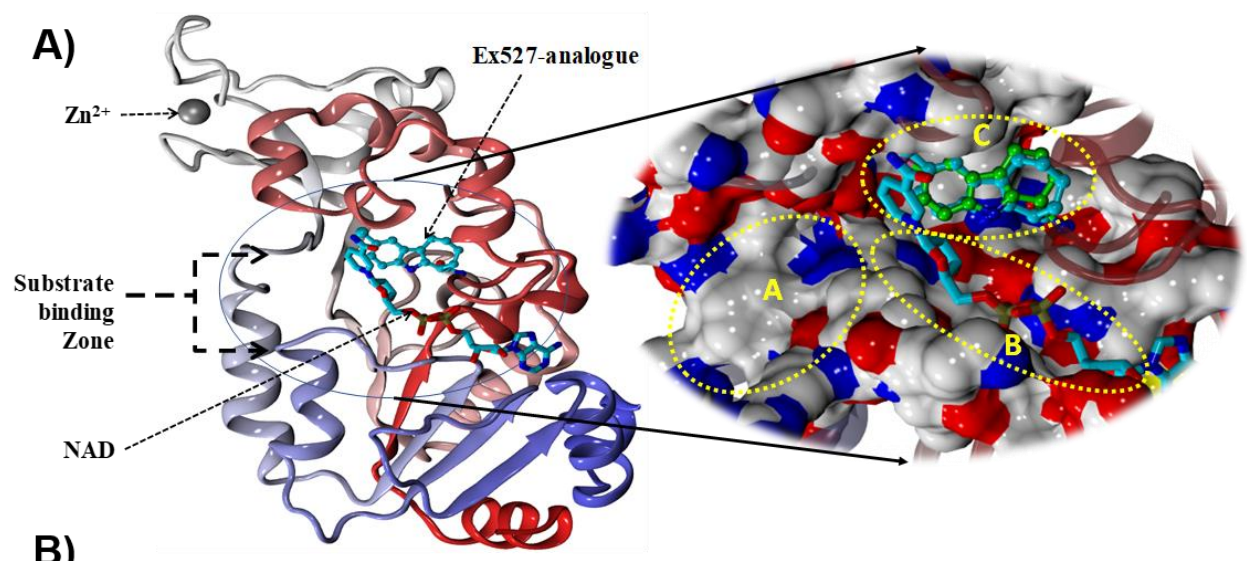

B)
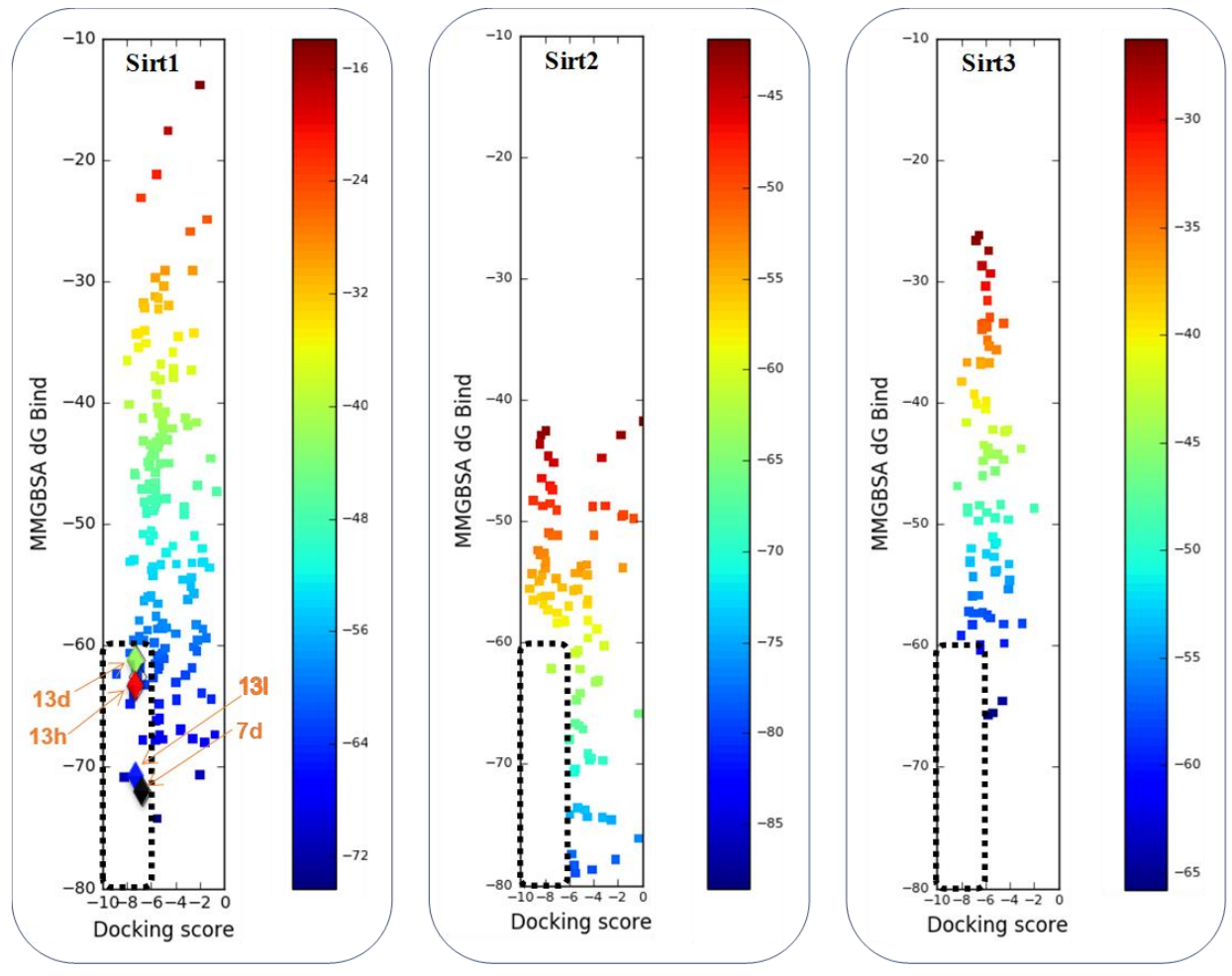

P a g e $51 \mid 59$ 
1 Figure 3. In-vitro evaluation of computationally promising compounds: (A\&B) The \%

2 viability of cancer cells in the presence of test compounds at different concentrations. Results were

3 represented as mean \pm SEM, n=3. (A) Assay in HepG2 cell, (B) Assay in MCF7 cells. (C) Immune

4 blotting shows the effect of control and test compounds on protein expression of Ac-p53 in HepG2 5 cells.

A)

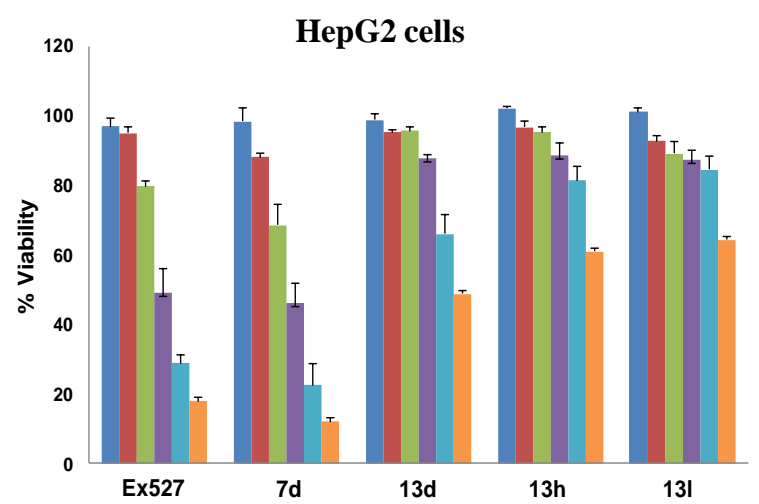

C)

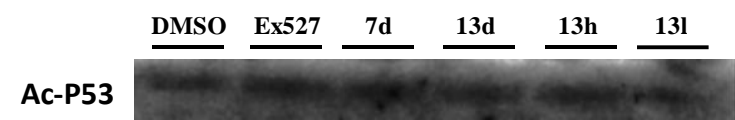

$\beta$-Actin

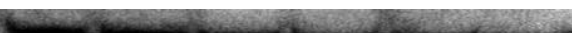

SIRT1

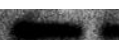

B)

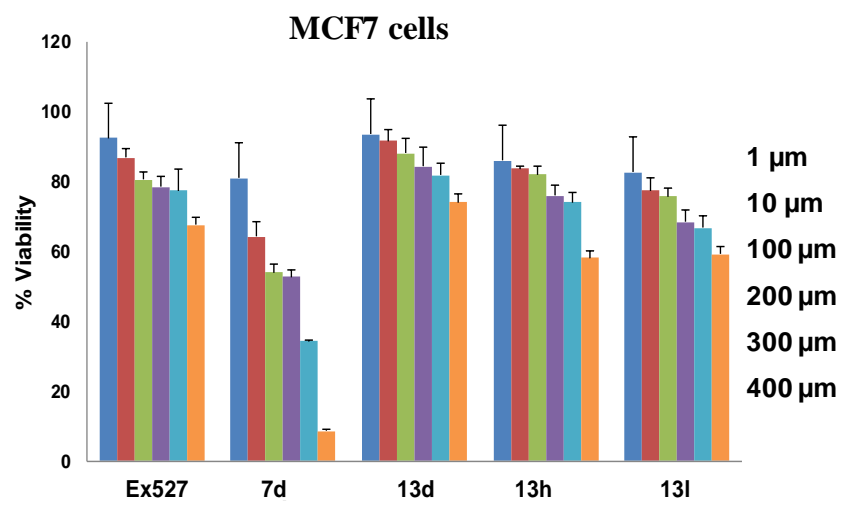


1 Figure 4. Molecular dynamics simulations reflects the significant changes in ligand 2 behavioural pattern: (A \& B) MD trajectory analysis of Apo Sirt1 and Protein-Ligand complexes

3 of 7d, 13d, 13h and 13l. (A) The Root mean square deviation (RMSD), of protein (all backbone

4 atoms) and ligand in coordinates as a function of the simulation time. (B) The Root mean square 5 fluctuation (RMSF) and $\triangle$ RMSF of C-alpha atoms of MD systems, Sirt1-apo, Sirt1-Ex527* and

6 Sirt1-7d. (C) Per-residue energy decomposition of Ex527*, 7d and 13d. The residue which 7 reflected the major contribution in binding free energies $\left(\Delta \mathrm{G}_{\mathrm{pbsa}} \leq-0.5 \mathrm{kcal} / \mathrm{mol}\right)$ is shown in the 8 graphs. The region highlighted with pink color background belongs to substrate binding site. (D) 9 The interaction map of $7 \mathrm{~d}, 13 \mathrm{~d}, 13 \mathrm{~h}, 13 \mathrm{l}$. The ligand $7 \mathrm{~d}, 13 \mathrm{~d}, 13 \mathrm{~h}$ and 131 are shown in 10 representation "stick" in color-type "element" with "C" in fluorescent cyan. The key residue within $113.5 \AA$ A cutoff from ligands are highlighted in color-type "element" with " $\mathrm{C}$ " in pink color. The $\mathrm{C}$ 12 alpha atom and side chain are shown in "sphere" and "stick" representation, respectively. 13 Backbone atoms showed for only those residues, which involved in HBs interaction. Backbone 14 atoms are shown in stick representation. Water (oxygen atom) within $2.5 \AA$ from ligand is shown 15 in sphere representation in red color. HBs are shown with dotted line and green color. 

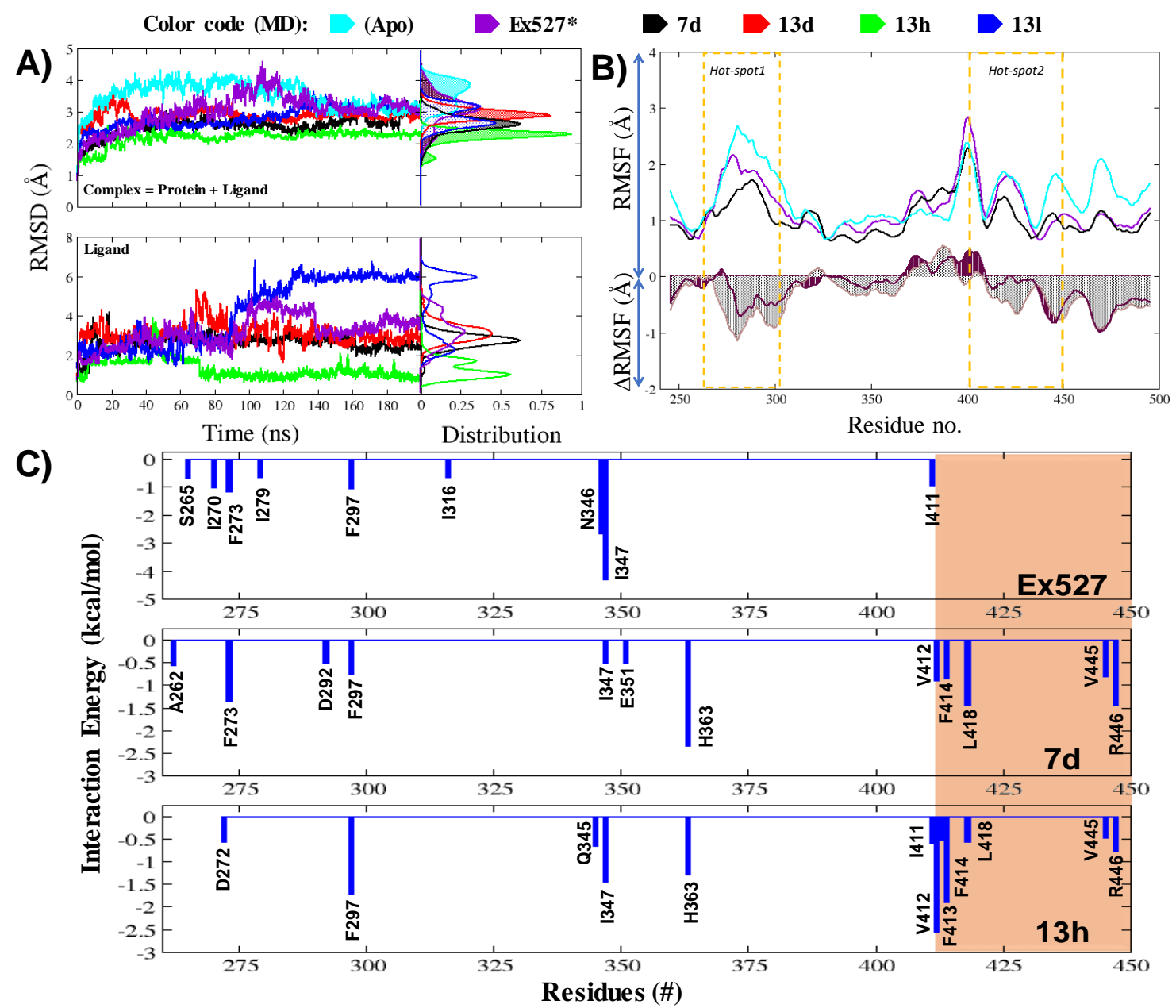

D)

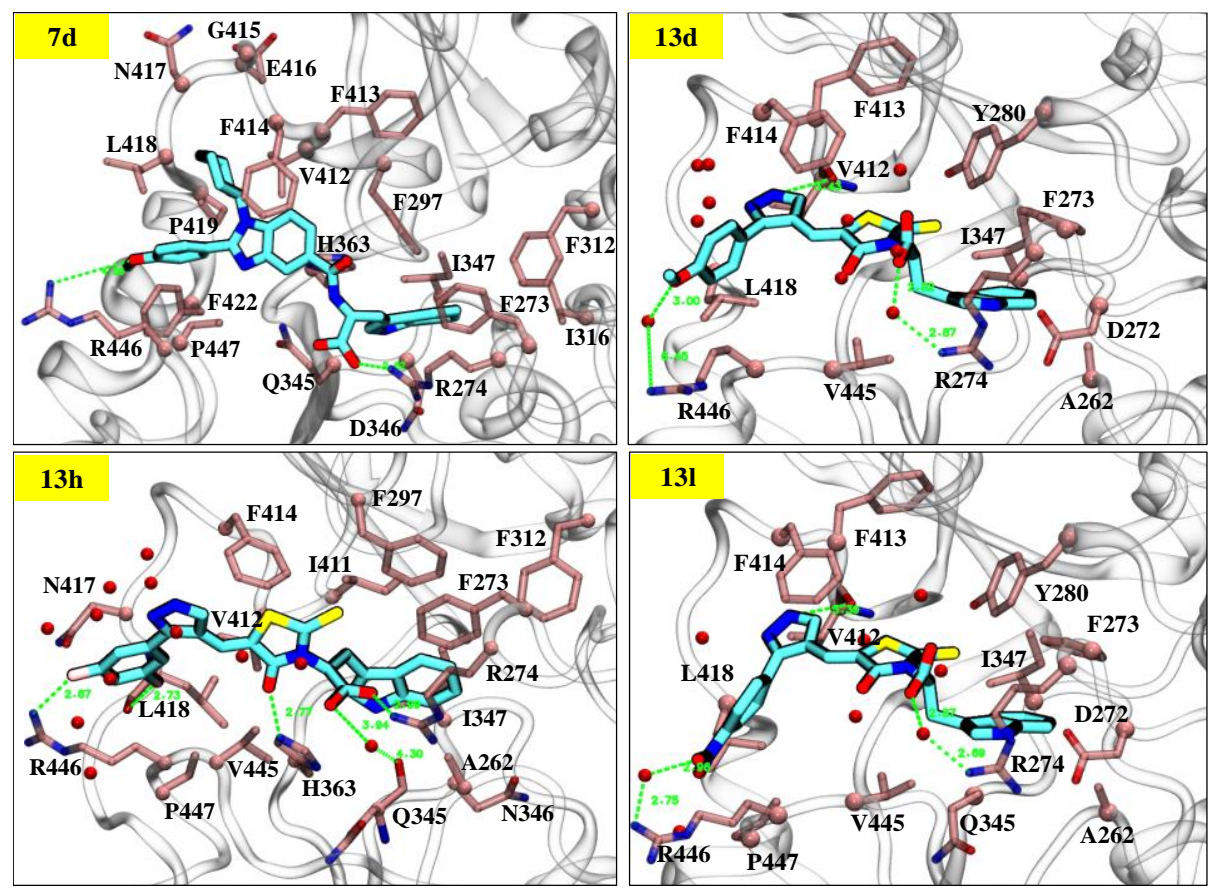

P a g e $54 \mid 59$ 
Figure 5. Establishment of SAR of Scheme1 compounds and their Molecular dynamics

2 simulations to reflects the structural differences: (A) Binding of scheme1 (Table 2) inhibitor (stick representation), with-OMe substitution in R1 position, in catalytic pocket of Sirt1. The compound

$47 \mathrm{~d}$ shown in representation sticks and color-type element with $\mathrm{C}$ in green, while rest other 5 compounds are shown in representation sticks, color-type 7a in yellow color, 7b in violet color and $67 \mathrm{c}$ in orange color. (B) Overlay binding of compounds $71-7 \mathrm{~d}$, and $7 \mathrm{~h}-7 \mathrm{~d}$ at catalytic pocket to 7 speculate the difference in their binding pose. Sirt1 catalytic pocket is shown in surface view. $7 \mathrm{~d}$ 8 is shown in representation "stick" in color-type "element" with " $\mathrm{C}$ " in fluorescent green, while 9 compound 71 and $7 \mathrm{~h}$ are shown in representation "ball and stick" in colour-type "element with "C" 10 in green. The zone of interest are highlighted with yellow circle. (C) MD trajectory analysis of 11 scheme1 molecules (71, 7h and 7d). The Root mean square deviation (RMSD) of protein (all 12 backbone atoms) and ligand (no hydrogen atom) in coordinates as a function of the simulation 13 time.

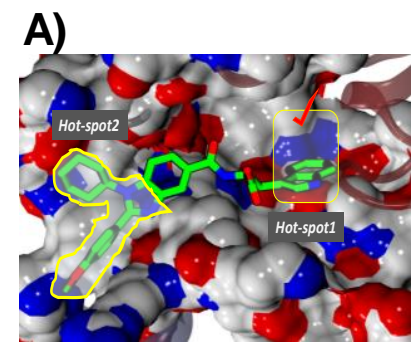

B)

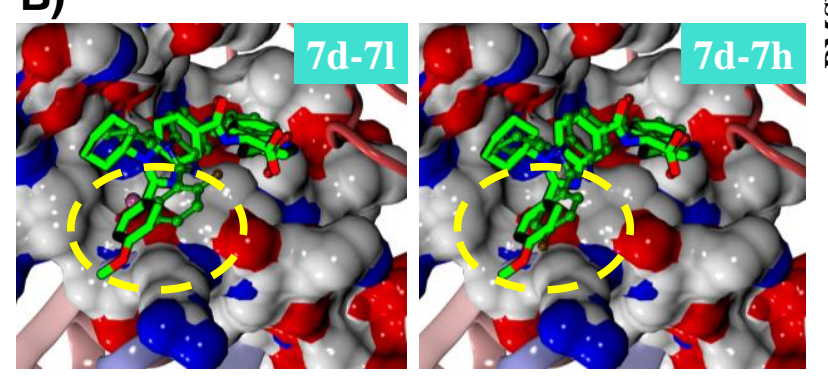

14

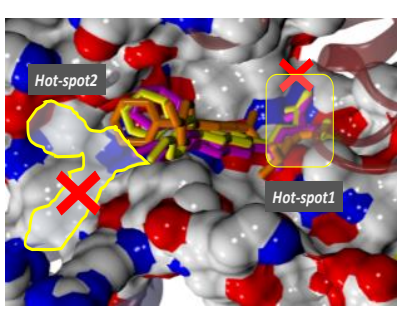

C)
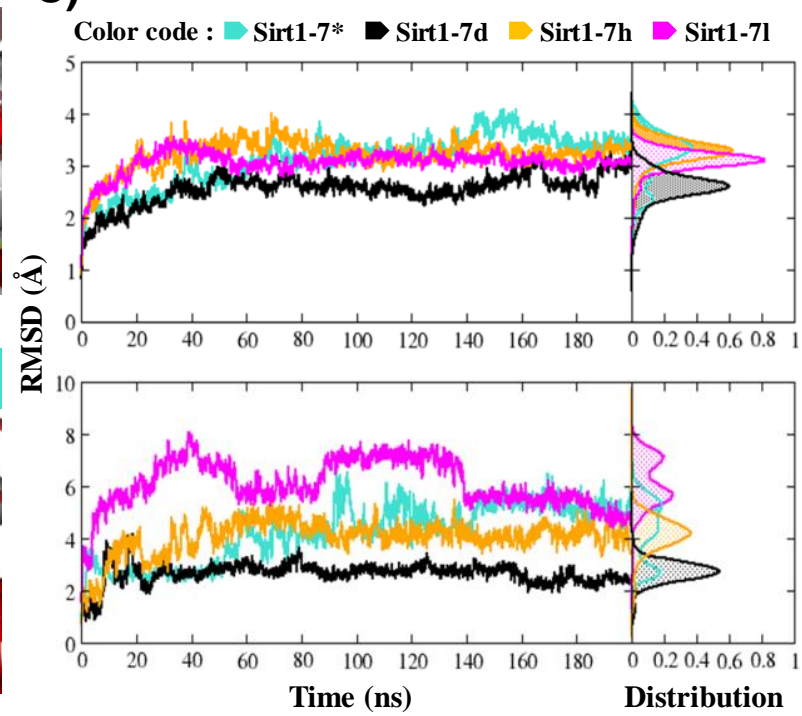
2 The sequence alignment of Sirt1, Sirt2 and Sirt3 PDB id. 4I5I, 4RMG and 4JSR, respectively. The region highlighted in cyan and deep cyan color represent substrate binding zone. (B) The enlarged

4 view of the sequence alignment of lower panel of substrate binding zone of Sirt1-3 (green color 5 box). The arrow sign marked the residues K444 and R446 playing key role in Sirt1 selectivity of $67 \mathrm{~d}$ via polar electrostatic interaction. (C and D) Electrostatic Surface view of ligand 7d (C) and 7 Sirt1 binding cavity (D). (E-G) The electrostatic surface potential (ESP) complementarity analysis 8 of $7 d$ with, Sirt1 (E), Sirt2 (F) and Sirt3 (G). Protein is shown in solid surface while 7d is shown 9 in mesh surface. The blue and red color surface represent positive and negative potential, 10 respectively. The region highlighted with green dotted circle highlights the selectivity zone at 11 substrate site.

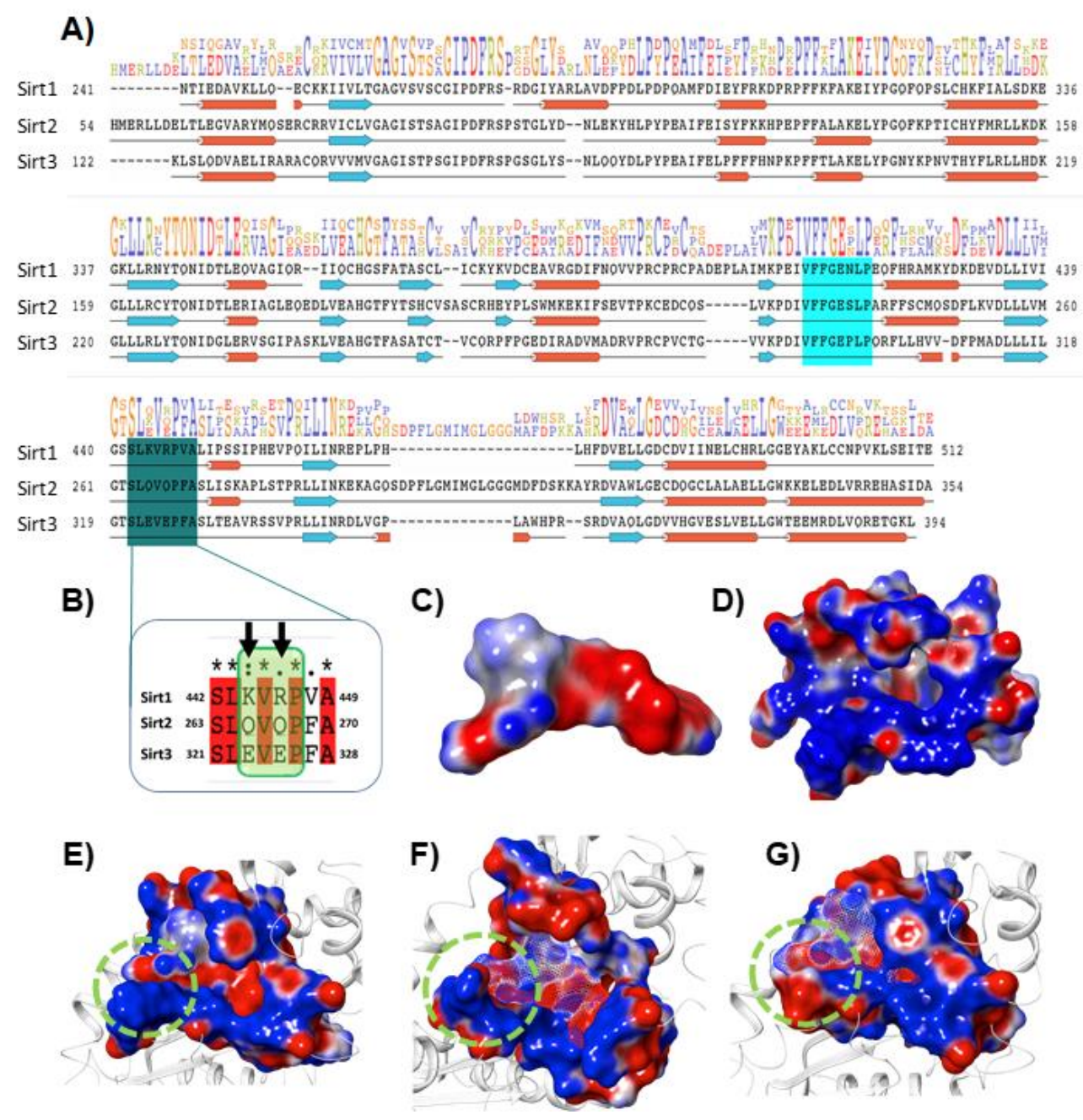


Tables:

2 Table 1. Structure of Scheme1 compounds with their elemental property, docking score, MM-

3 GBSA binding energy and enzyme-based inhibition activity. The biological evaluation of enzyme-

4 based inhibitory activity of test compounds at $10 \mu \mathrm{m}$ concentration was obtained against 5 recombinant human Sirt1, Sirt2 and Sirt3.

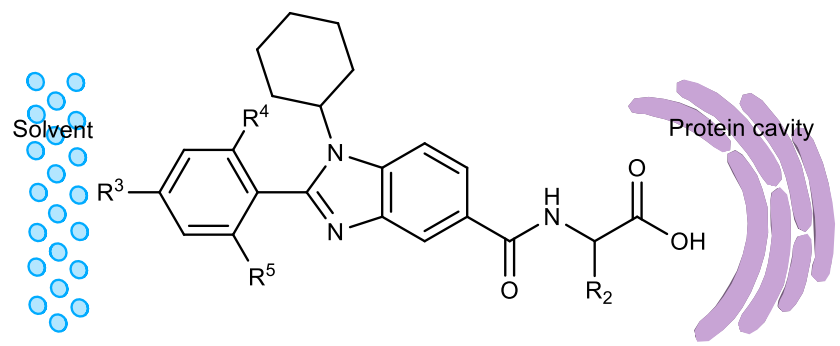

\begin{tabular}{|c|c|c|c|c|c|c|c|c|c|c|}
\hline \multirow{2}{*}{ Comp. } & \multirow{2}{*}{$\mathbf{R}_{2}$} & \multirow{2}{*}{$\mathbf{R}^{3}$} & \multirow{2}{*}{$\mathbf{R}^{4} / \mathbf{R}^{5}$} & \multirow{2}{*}{$\begin{array}{l}\text { Mol. } \\
\text { mass }\end{array}$} & \multirow{2}{*}{ cLogP } & \multirow{2}{*}{$\begin{array}{l}\text { Dock } \\
\text { Score } \\
\text { (Sirt1) } \\
\end{array}$} & \multirow{2}{*}{$\underset{(\mathbf{S}}{\Delta \mathbf{G}_{\text {bind }}}$} & \multicolumn{3}{|c|}{$\%$ inhibition at $10 \mu \mathrm{M}$} \\
\hline & & & & & & & & Sirt1 & Sirt2 & Sirt3 \\
\hline $7 \mathrm{a}$ & $-\mathrm{C}$ & $-\mathrm{OMe}$ & $-\mathrm{H}$ & 421 & 5.05 & -6.26 & -58.96 & 88.03 & -59.54 & -112.65 \\
\hline $7 b$ & & $-\mathrm{OMe}$ & $-\mathrm{H}$ & 450 & 5.98 & -7.06 & -59.49 & 88.18 & -84.09 & -88.31 \\
\hline $7 \mathrm{c}$ & & $-\mathrm{OMe}$ & $-\mathrm{H}$ & 464 & 6.51 & -6.68 & -58.85 & 86.34 & -37.06 & -127.63 \\
\hline $7 \mathrm{~d}$ & & $-\mathrm{OMe}$ & $-\mathrm{H}$ & 537 & 6.46 & -6.70 & -72.08 & 89.99 & -13.81 & -104.72 \\
\hline $7 \mathrm{e}$ & $-\mathrm{C}$ & $-\mathrm{F}$ & $-\mathrm{H}$ & 409 & 5.18 & -6.51 & -54.45 & $<50$ & - & - \\
\hline $7 f$ & & $-\mathrm{F}$ & $-\mathrm{H}$ & 437 & 6.11 & -7.40 & -54.66 & $<50$ & - & - \\
\hline $7 \mathrm{~g}$ & & $-\mathrm{F}$ & $-\mathrm{H}$ & 451 & 6.64 & -6.08 & -58.20 & 88.82 & -76.30 & -80.68 \\
\hline $7 \mathrm{~h}$ & & $-\mathrm{F}$ & $-\mathrm{H}$ & 525 & 6.59 & -5.84 & -61.60 & 86.83 & -25.70 & -99.31 \\
\hline $7 \mathrm{i}$ & $-\mathrm{C}$ & $-\mathrm{H}$ & $-\mathrm{Cl} / \mathrm{F}$ & 472 & 6.58 & -7.08 & -49.04 & $<50$ & - & - \\
\hline $7 \mathrm{j}$ & & $-\mathrm{H}$ & $-\mathrm{Cl} / \mathrm{F}$ & 486 & 7.11 & -5.33 & -33.49 & $<50$ & - & - \\
\hline $7 \mathrm{k}$ & & $-\mathrm{H}$ & $-\mathrm{Cl} / \mathrm{F}$ & 559 & 7.05 & -6.61 & -56.97 & $<50$ & - & - \\
\hline 71 & & $-\mathrm{H}$ & $-\mathrm{Cl} / \mathrm{F}$ & 559 & 7.05 & -6.61 & -56.97 & $<50$ & - & - \\
\hline
\end{tabular}

7

8

9 *highlights are showing ligands selected for further biological and MD studies on basis of cut-off 10 score (docking score $\leq-6.0$ and $\Delta \mathrm{G}_{\text {bind }} \leq-60.0 \mathrm{kcal} / \mathrm{mol}$ ). 
1 Table 2. Structure of Scheme2 compounds with their elemental property, docking score, MM-

2 GBSA binding energy ( $\left.\Delta \mathrm{G}_{\text {bind }}\right)$ and enzyme-based inhibition activity. The biological evaluation

3 of enzyme-based inhibitory activity of test compounds at $10 \mu \mathrm{m}$ concentration was obtained

4 against recombinant human Sirt1, Sirt2 and Sirt3.
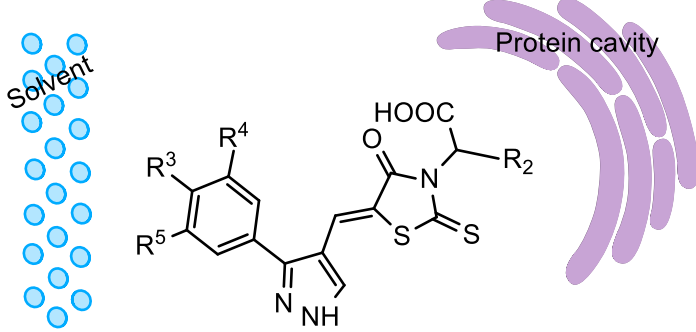

\begin{tabular}{|c|c|c|c|c|c|c|c|c|c|c|}
\hline \multirow{2}{*}{ Comp. } & \multirow{2}{*}{$\mathbf{R}$} & \multirow{2}{*}{$\mathbf{R}_{\mathbf{1}}$} & \multirow{2}{*}{$\mathbf{R}_{2} / \mathbf{R}_{3}$} & \multirow{2}{*}{$\begin{array}{l}\text { Mol. } \\
\text { Mass }\end{array}$} & \multirow{2}{*}{ cLogP } & \multirow{2}{*}{$\begin{array}{c}\text { Dock } \\
\text { Score } \\
\text { (Sirt1) }\end{array}$} & \multirow{2}{*}{$\begin{array}{l}\Delta \mathbf{G}_{\text {bind }} \\
(\text { Sirt1) }\end{array}$} & \multicolumn{3}{|c|}{$\%$ inhibition at $10 \mu \mathrm{M}$} \\
\hline & & & & & & & & Sirt1 & Sirt2 & Sirt3 \\
\hline $13 \mathrm{a}$ & $-\mathrm{H}$ & $-\mathrm{OMe}$ & $-\mathrm{H}$ & 375.42 & 1.65 & -6.537 & -47.191 & - & - & - \\
\hline $13 b$ & $-\mathrm{CH}_{3}$ & $-\mathrm{OMe}$ & $-\mathrm{H}$ & 389.44 & 1.96 & -6.176 & -46.735 & - & - & - \\
\hline $13 \mathrm{c}$ & & $-\mathrm{OMe}$ & $-\mathrm{H}$ & 465.08 & 3.38 & -7.436 & -40.642 & - & - & - \\
\hline $13 d$ & & $-\mathrm{OMe}$ & $-\mathrm{H}$ & 504.58 & 3.37 & -7.258 & -63.4 & 90.64 & -41.54 & -48.19 \\
\hline $13 \mathrm{e}$ & $-\mathrm{H}$ & $-\mathrm{H}$ & $-\mathrm{F}$ & 381.37 & 1.97 & -6.36 & -48.847 & - & - & - \\
\hline $13 \mathrm{f}$ & $-\mathrm{CH}_{3}$ & $-\mathrm{H}$ & $-\mathrm{F}$ & 395.40 & 2.28 & -6.511 & -48.219 & - & - & - \\
\hline $13 \mathrm{~g}$ & & $-\mathrm{H}$ & $-\mathrm{F}$ & 471.50 & 3.7 & -7.42 & -52.957 & - & - & - \\
\hline $13 \mathrm{~h}$ & & $-\mathrm{H}$ & $-\mathrm{F}$ & 510.53 & 3.69 & -7.206 & -60.234 & 89.15 & -17.73 & -46.05 \\
\hline $13 i$ & $-\mathrm{H}$ & $-\mathrm{NO}_{2}$ & $-\mathrm{H}$ & 390.39 & 1.46 & -6.971 & -59.301 & - & - & - \\
\hline $13 \mathrm{j}$ & $-\mathrm{CH}_{3}$ & $-\mathrm{NO}_{2}$ & $-\mathrm{H}$ & 404.42 & 1.77 & -7.699 & -53.106 & - & - & - \\
\hline $13 \mathrm{k}$ & & $-\mathrm{NO}_{2}$ & $-\mathrm{H}$ & 480.51 & 3.19 & -6.267 & -56.012 & - & - & - \\
\hline 131 & & $-\mathrm{NO}_{2}$ & $-\mathrm{H}$ & 519.55 & 3.18 & -7.088 & -70.882 & 89.64 & -24.59 & -34.51 \\
\hline
\end{tabular}

7

8 *highlights are showing ligands selected for further biological and MD studies on basis of cut-off 9 score (docking score $\leq-6.0$ and $\Delta \mathrm{G}_{\text {bind }} \leq-60.0 \mathrm{kcal} / \mathrm{mol}$ ). 
1 Table 3: Determination of cell-based inhibitory activity and $\mathrm{IC}_{50}$ of test compounds and control.

2 The cell-based inhibitory activity was estimated at $10 \mu \mathrm{M}$ concentration in HepG2 cells against

3 Sirt1 and Sirt2/3. IC 50 values are calculated in human recombinant Sirt1. Results were represented

4 as mean $\pm \mathrm{SEM}, \mathrm{n}=3$.

5

6

\begin{tabular}{|c|c|c|c|}
\hline Comp. & \% Inhibition of Sirt1 & $\begin{array}{c}\text { \% Inhibition of } \\
\text { Sirt2 and Sirt3 }\end{array}$ & $\begin{array}{c}\text { IC50 }(\boldsymbol{\mu M}) \\
\text { Sirt1 }\end{array}$ \\
\hline $7 \mathrm{a}$ & $<1$ & - & - \\
\hline $7 \mathrm{~b}$ & $<1$ & - & - \\
\hline $7 \mathrm{c}$ & $3.235 \pm 0.2799$ & $5.21 \pm 0.785$ & - \\
\hline $7 \mathrm{~d}$ & $38.333 \pm 0.3719$ & $19.89 \pm 0.895$ & $0.77+0.04$ \\
\hline $7 \mathrm{~g}$ & $<1$ & - & - \\
\hline $7 \mathbf{h}$ & $<1$ & - & - \\
\hline $13 \mathrm{~d}$ & $36.338 \pm 0.9965$ & $6.04 \pm 0.915$ & $0.71+0.03$ \\
\hline $13 \mathrm{~h}$ & $48.540 \pm 0.9175$ & $9.53 \pm 0.654$ & $0.66+0.02$ \\
\hline 131 & $30.061 \pm 0.2338$ & $9.47 \pm 0.9236$ & $0.73+0.06$ \\
\hline Ex527 & $33.330 \pm 0.647$ & $15.21 \pm 0.9985$ & $0.60+0.02$ \\
\hline
\end{tabular}

7

8

\#biological assay control or standard compound.

*Highlights are showing compounds with highest Sirt1 inhibition. 
